\title{
AVALIAÇÃO AMBIENTAL ESTRATÉGICA PARA PLANOS DE USO E OCUPAÇÃO DO SOLO: UM ESTUDO SOBRE O PLANO DIRETOR MUNICIPAL
}

\author{
Tese apresentada à Escola de Engenharia de \\ São Carlos, como parte dos requisitos para \\ obtenção do Título de Mestre em Ciências da \\ Engenharia Ambiental
}

Prof. Tit. MARCELO PEREIRA DE SOUZA

Orientador

São Carlos - SP 
AUTORIZO A REPRODUÇÃO E DIVULGAÇÃO TOTAL OU PARCIAL DESTE TRABALHO, POR QUALQUER MEIO CONVENCIONAL OU ELETRÓNICO, PARA FINS DE ESTUDO E PESQUISA, DESDE QUE CITADA A FONTE.

Ficha catalográfica preparada pela Seção de Tratamento da Informação do Serviço de Biblioteca - EESC/USP

Fabbro Neto, Francisco

Avaliação ambiental estratégica para planos de uso e ocupação do solo : um estudo sobre o plano diretor municipal / Francisco Fabbro Neto ; orientador Marcelo Pereira de Souza. -- São Carlos, 2010.

Dissertação (Mestrado-Programa de Fós Graduaçầo e Área de Concentração em Ciências da Engenharia Ambiental) -- Escola de Engenharia de São Carlos da Universidade de São Paulo, 2010.

1. Impactos ambientais - avaliação. 2. Avaliação ambiental estratégica. 3. Solo - uso e ocupação. 4. Plano diretor municipal. I. Título. 


\section{FOLHA DE JULGAMENTO}

Candidato(a): Arquiteto e Urbanista FRANCISCO FABBRO NETO.

Dissertação deffendida e julgađa em 18/03/2010 perante a Comissão Julgadora:
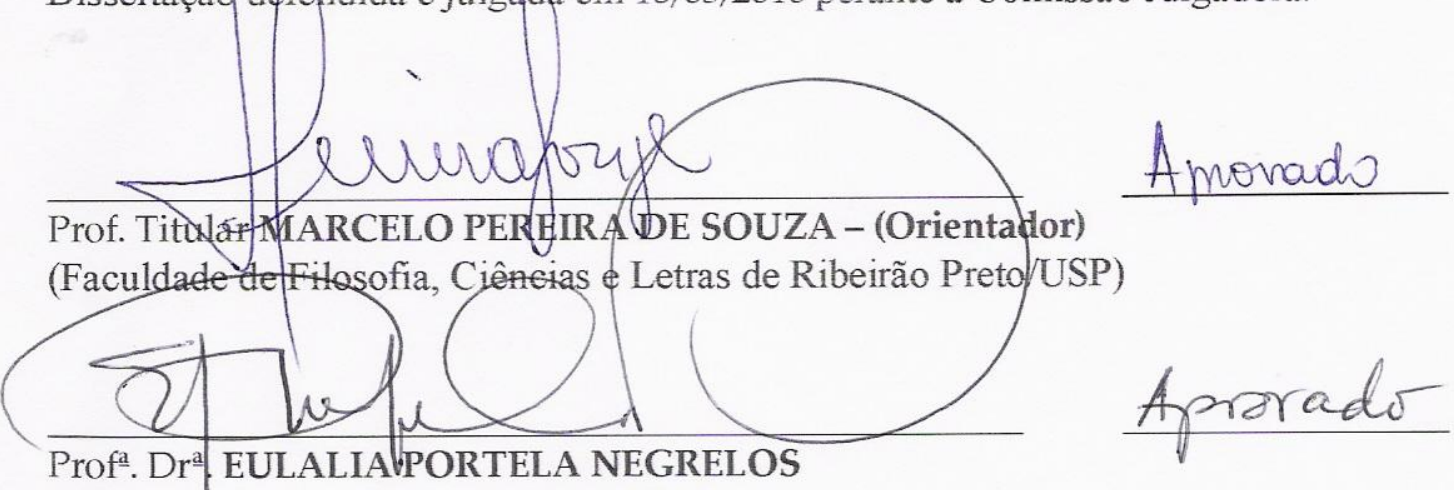

(Escola d£ Engenharia de São Carlos/USP)
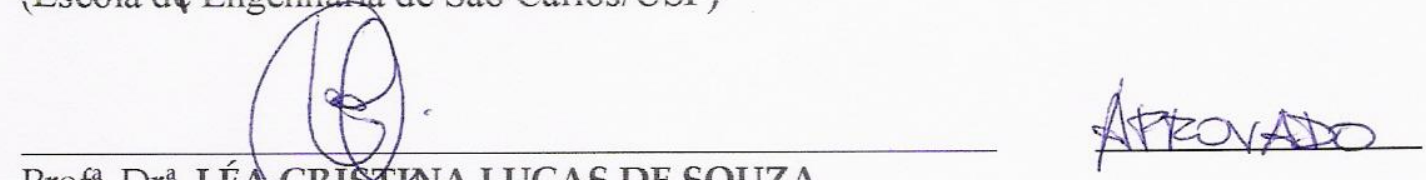

Profa ${ }^{\text {. Dra }}$. LÉACRISAINA LUCAS DE SOUZA

(Universidade Federal de São Carlos/UFSCar)
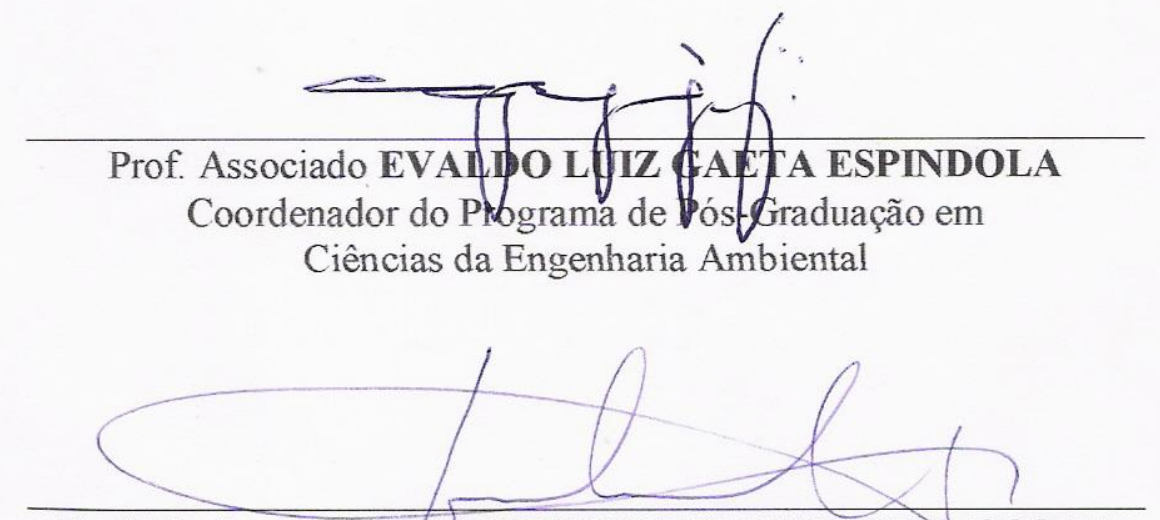

Prof. Titular GERALDO ROBERTO MARTINS DA COSTA

Presidente da Comissão da Pós-Graduação da EESC 
Para minha mãe, Cidinha, exemplo de força e dedicação, que sempre me estimulou para os estudos e para a vida acadêmica. 


\section{AGRADECIMENTOS}

Ao prof. Marcelo Pereira de Souza, pela confiança depositada em mim e em meu trabalho.

Aos professores Nemésio Batista Salvador e Tadeu Fabrício Malheiros pelas importantes contribuições na etapa de qualificação deste projeto de pesquisa.

Aos professores da Escola de Engenharia de São Carlos e da Universidade Estadual de Campinas que contribuíram para o meu amadurecimento das questões ambientais.

Aos funcionários do Centro de Recursos Hídricos e Ecologia Aplicada pela paciência e dedicação.

À Isabel pelos importantes momentos de esclarecimentos na etapa final desta pesquisa.

Aos amigos Denise, Clara, Simone, Aline, Mariana, Angêla, Karina, Simone P., Natália, Tiago e Neto por me ouvirem e compartilharem sobre os desafios do processo de pesquisa acadêmica.

Aos amigos do Núcleo de Estudos de Política Ambiental e do Núcleo de Estudos de Ecologia Aquática que ajudaram a transformar o período desta pesquisa como algo divertido e agradável, vocês foram fundamentais!

Aos colegas de pós-graduação, que movem a pesquisa científica no País.

Ao CNPq pelo financiamento desta pesquisa. 
FABBRO NETO, Francisco - Avaliação Ambiental Estratégica para Planos de Uso e Ocupação do Solo: um estudo sobre o Plano Diretor Municipal - Dissertação (Mestrado)

- Escola de Engenharia de São Carlos, Universidade de São Paulo - São Carlos, 2010.

\section{RESUMO}

A avaliação de impacto ambiental realizada no Brasil limitada aos projetos apresenta dificuldades para o incremento da qualidade ambiental em função das características da área. Alguns países aplicam a Avaliação Ambiental Estratégica - AAE para a avaliação de políticas, planos e programas, o que permite aos tomadores-de-decisão incluir a variável ambiental com maior antecedência, aumentando as possibilidades de adequação das propostas. O objetivo desta pesquisa é identificar as possíveis contribuições da AAE para o planejamento de uso e ocupação do solo municipal, com aproximação da realidade brasileira pela experiência do município de São Carlos-SP com seu Plano Diretor Municipal - PDM, seguido da sistematização dos instrumentos ambientais aplicados para o planejamento de uso e ocupação do solo municipal. A metodologia foi pautada na seleção de 2 relatórios de AAE e 1 PDM, com a identificação de etapas e características AAE (regulamentada pela Diretiva Européia 2001/42) e do Plano Diretor Municipal (regulamentado pela Lei Federal 10.257/01 Estatuto da Cidade), o cruzamento dos diferentes instrumentos com a proposição de aplicação da AAE segundo os procedimentos do Estatuto da Cidade, para enfim, chegar a uma proposta de modelo para o município de São Carlos. Experiências de aplicação mostram como a AAE contribui para o direcionamento sustentável do desenvolvimento municipal, integrando o gerenciamento dos conflitos locais, os interesses políticos e a participação da sociedade, fortalecendo a gestão democrática da tomada-de-decisão. A pesquisa indica que a AAE pode contribuir para atingir os objetivos de sustentabilidade pela avaliação e integração do PDM com outros instrumentos de planejamento, sendo que esta integração possibilita que procedimentos participativos auxiliem a romper as barreiras entre disciplinas e grupos de interesse, permitindo que somem força de trabalho para as autoridades responsáveis pela implementação das ações de planejamento.

PALAVRAS-CHAVE: Impactos Ambientais, Avaliação Ambiental Estratégica, Solo, Uso e Ocupação, Plano Diretor Municipal 
FABBRO NETO, Francisco - Strategic Environmental Assessment and Land Use Planning: a study of City Master Plan - Dissertação (Mestrado) - Escola de Engenharia de São Carlos, Universidade de São Paulo - São Carlos, 2010.

\begin{abstract}
:
The environmental impact assessment in Brazil is limited for projects have presented difficulties to improve the environmental quality in function of the local characteristics. Therefore some countries have applied the Strategic Environmental Assessment - SEA for management policy, plans and programs, which allows decision makers to input environmental issues earlier and create more opportunities to suit the actions. The main aim of this research is to identify the contributions of the SEA to land use municipal planning with an approach to Brazilian public management, through the Master Plan Development (MPD) of São Carlos - SP. As methodology were select 2 AAE's report (regulated by European Directive 2001/42/EC) and 1 MPD (regulated by National Law 10.257/01 - City's Statute), crossing the different tools, following the AAE's application with the City's Statute procedures, at end, a proposal of a model to São Carlos. Applications' experiences show how the SEA can drive the urban development toward sustainable cities, including the management of local conflicts, political interests and public participation, strengthening the democratic management. The research indicates the possible contributions of AAE to sustainable aims by the assessment and integration of PDM with others planning tools, which can help to win the sectors and interests groups barriers, allowing to group the work of different responsible for planning actions.
\end{abstract}

WORD-KEY: Environmental Impact, Strategic Environmental Assessment, Soil, Land Use, City Master Plan 


\section{LISTA DE FIGURAS}

FIGURA 01 Avaliação de Impactos Ambientais em cascata............................. 08

FIGURA 02 Ligações entre AAE e tomada de decisão estratégica.................... 10

FIGURA 03 Ligações entre objetivos, indicadores e outras etapas de AAE..... 12

FIGURA 04 Tomada de decisão sem e com a AAE.......................................... 14

FIGURA 05 Representação esquemática da determinação dos FCDs............... 26

FIGURA 06 Município de Monção em Portugal................................................. 28

FIGURA 07 Região de Devon na Inglaterra................................................... 38

FIGURA 08 Municípios da região de Devon................................................... 38

FIGURA 09 Metodologia para seleção de contexto e bases de referência.......... 40

FIGURA 10 UGRHI da Bacia Tietê-Jacaré.................................................... 62

FIGURA 11 UGRHI da Bacia Mogi-Gauçu................................................... 64

FIGURA 12 Taxa Geométrica de crescimento populacional............................. 66

FIGURA 13 Desenvolvimento urbano de São Carlos......................................... 67

FIGURA 14 Variação da densidade populacional.............................................. 68

FIGURA 15 Concentração de renda por chefes de família................................ 68

FIGURA 16 Bacias Hidrográficas no território de São Carlos.......................... 70

FIGURA 17 Drenagem urbana................................................................. 71

FIGURA 18 Edificação Padrão...................................................................... 72

FIGURA 19 Macrozona Urbana e Macrozona Rural......................................... 77

FIGURA 20 Zoneamento das macrozonas urbana e rural................................. 78

FIGURA 21 Ligações entre AAE, tomada de decisão e Estatuto da Cidade...... 87

FIGURA 22 Esquemas das etapas do PDMSC................................................ 93

FIGURA 23 Esquemas das etapas do PDMSC com AAE................................ 94 


\section{LISTA DE TABELAS}

TABELA $01 \quad$ Temas relativos à biodiversidade..................................................... 29

TABELA $02 \quad$ SWOT relativo à biodiversidade..................................................... 30

TABELA $03 \quad$ Temas relativos ao Patrimônio Cultural.............................................. 31

TABELA $04 \quad$ SWOT relativo ao Patrimônio Cultural............................................. 31

TABELA $05 \quad$ Temas relativos aos Fatores Físicos................................................ 32

TABELA $06 \quad$ SWOT relativo aos Fatores Físicos.................................................. 33

TABELA $07 \quad$ Temas relativos ao Ordenamento Territorial.................................... 34

TABELA $08 \quad$ SWOT relativo ao Ordenamento Territorial.................................... 35

TABELA 09 Temas relativos à Conservação Natural............................................ 42

TABELA $10 \quad$ Temas relativos ao Patrimônio.............................................................. 42

TABELA 11 Temas relativos à Paisagem............................................................. 43

TABELA 12 Temas relativos à Água.................................................................. 43

TABELA 13 Temas relativos ao Clima............................................................... 44

TABELA 14 Temas relativos à Qualidade do Ar................................................. 44

TABELA $15 \quad$ Temas relativos à Terra e Solo......................................................... 44

TABELA $16 \quad$ Temas relativos ao Consumo.......................................................... 45

TABELA $17 \quad$ Temas relativos ao Transporte........................................................ 45

TABELA 18 Temas relativos à Participação.......................................................... 46

TABELA 19 Temas relativos à Habitação.............................................................. 46

TABELA $20 \quad$ Temas relativos à Saúde................................................................... 46

TABELA 21 Temas relativos aos Serviços.......................................................... 47

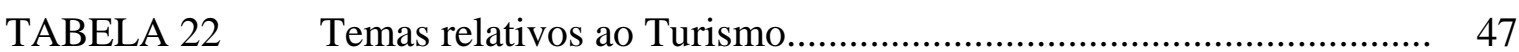

TABELA 23 Temas relativos ao Crescimento Econômico.................................... 48

TABELA 24 Temas relativos à Diversificaçãa de Negócios.................................. 48

TABELA $25 \quad$ Temas relativos ao Emprego.......................................................... 48

TABELA $26 \quad$ Temas relativos às Vendas............................................................... 49 


\section{LISTA DE SIGLAS}

\section{AAE}

$\mathrm{AC}$

AIA

APA

art.

CEAT

$\mathrm{CF}$

$\mathrm{CMM}$

$\mathrm{CO} 2$

CONAMA

EIA

EMBRAPA

ETE

FA

FCD

IBGE

MDDC

MPF

PDM

PDMSC

PMSC

POT

PPP

QE

QRE

RIMA

SERFHAU

SP

SWOT

UFSCar

UGRHI

UNESP

USP
Avaliação Ambiental Estratégica

Áreas de Conservação

Avaliação de Impacto Ambiental

Área de Proteção Ambiental

Artigo

Centro Empresarial de Alta Tecnologia

Constituição Federal

Câmara Municipal de Monção

Dióxido de Carbono

Conselho Nacional de Meio Ambiente

Estudo de Impacto Ambiental

Empresa Brasileira de Pesquisa Agropecuária

Estação de Tratamento de Esgoto

Fatores Ambientais

Fatores Críticos de Decisão

Instituto Brasileiro de Geografia e Estatística

Mid Devon District Council

Ministério Público Federal

Plano Diretor Municipal

Plano Diretor Municipal de São Carlos

Prefeitura Municipal de São Carlos

Plano de Ordenamento Territorial

Política, Plano e Programa

Objetivos Estratégicos

Quadro de Referência Estratégico

Relatório de Impacto Ambiental

Serviço Federal de Habitação de Urbanismo

São Paulo

Forças, Fraquezas, Oportunidades e Riscos

Universidade Federal de São Carlos

Unidade de Gerenciamento de Recursos Hídricos

Universidade Júlio de Mesquita Filho

Universidade de São Paulo 


\section{SUMÁRIO}

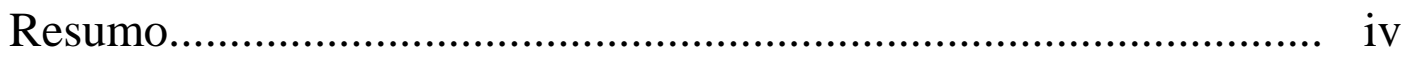

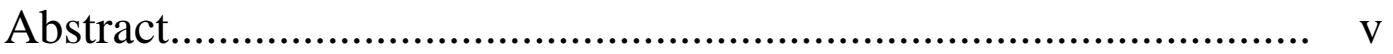

1. Introdução e Justificativa.................................................................. 1

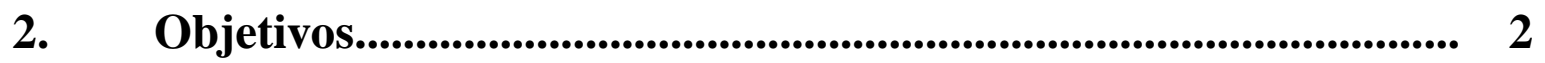

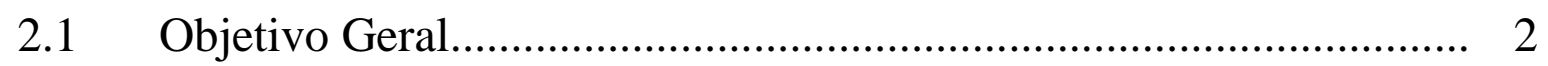

2.2 Objetivos Específicos.......................................................... 2

3. Metodologia................................................................................................ 3

4. Avaliação de Impacto Ambiental............................................................. 6

4.1 Avaliação Ambiental Estratégica.................................................... 7

4.1.1 Etapas Sequenciais da Avaliação Ambiental Estratégica................... 11

4.2 Práticas de AAE para planos de uso e ocupação do solo.................... 15

4.3 Relatórios de AAE aplicados a planos municipais de uso e ocupação do solo

4.3.1 AAE para o Plano Diretor de Monção - Portugal............................... 23

4.3.2 AAE para o Plano de Uso e Ocupação do Solo de Mid Devon -

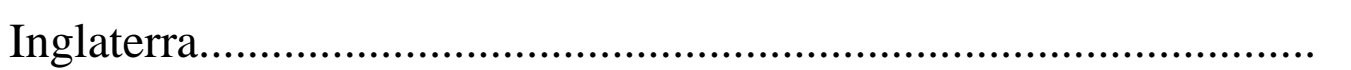

5. Planejamento Municipal de Uso e Ocupação do Solo.................... 51

5.1 Uso e Ocupação do Solo na Constituição Federal do Brasil.............. 51

$5.2 \quad$ Estatuto da Cidade ..................................................................... 54

$5.3 \quad$ Plano Diretor Municipal............................................................... 57 
6. Estudo de Caso: Gerenciamento Ambiental e o Plano Diretor Municipal de São Carlos........................................................................ 60

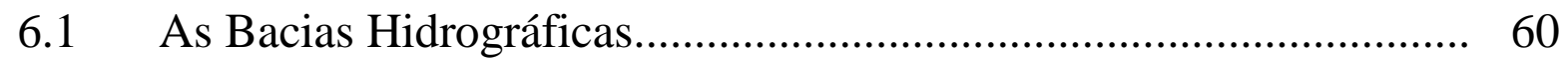

6.2 O Município de São Carlos........................................................... 65

6.3 Plano Diretor Municipal de São Carlos............................................ 72

7. AAE, tomada de decisão e o Estatuto da Cidade........................... 85

7.1 Contribuições da realização da AAE para os planos municipais de uso e ocupação do solo e para o Plano Diretor Municipal de São

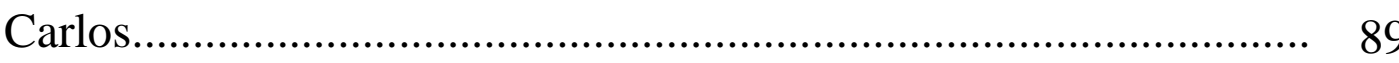

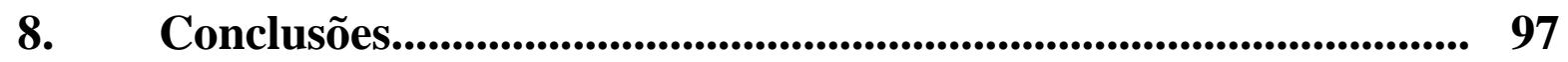

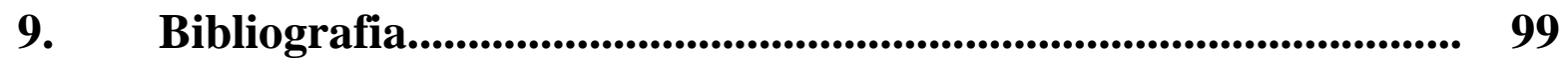




\section{INTRODUÇÃO E JUSTIFICATIVA}

A viabilidade ambiental das transformações do espaço urbano em função das decisões adotadas pelo poder público pode ser sentida de diferentes maneiras. Para Sánchez (2006), o conceito de viabilidade ambiental não é único. A noção da sustentabilidade para o desenvolvimento das cidades é cada vez mais necessária, tendo em vista que já na década de 1990 a maior parte da população vivia em área urbana. (JACOBI, 1996).

Diferentes instrumentos são criados para o gerenciamento ambiental de planejamento municipal, referentes ao papel do poder público na regulação do desenvolvimento, sendo que, na presente pesquisa, é feito o recorte sobre o uso e ocupação do solo municipal dentro das ações de desenvolvimento urbano, devido à complexidade das relações entre os outros setores da política urbana, como exemplo, os setores de habitação, transporte e saneamento.

Segundo Burgess et. al. (1997), o planejamento centralizado cada vez mais perde espaço para os processos participativos, o que envolve a descentralização das decisões e o repasse de responsabilidades acompanhado por conflitos de interesses entre os diversos atores de desenvolvimento, como a iniciativa privada e as demandas sociais. A responsabilidade pelo desenvolvimento das cidades é então compartilhada, por meio de privatizações de serviços públicos e pela noção empreendedora que cada vez mais atinge os gestores municipais.

O licenciamento ambiental no Brasil é limitado às etapas de aprovação de projetos de empreendimentos que contenham potencial significativo de impacto ambiental, sendo que este modelo apresenta várias lacunas em função do instrumento de gestão vigente, a saber, os Estudos de Impacto Ambiental e respectivos Relatórios de Impacto Ambiental, regulamentados pela Resolução do Conselho Nacional do Meio Ambiente, CONAMA 01/86. Estes instrumentos fazem parte daqueles estipulados pela Política Nacional do Meio Ambiente - Lei Federal 6938/81.

De acordo com Silva e Teixeira (2009) e Stephan (2007), o instrumento de planejamento urbano no Brasil, o que inclui a regulação do uso e ocupação de solo, é o Plano Diretor Municipal, regulamentado pelo Estatuto da Cidade - Lei Federal 10.257/01, que incorpora a descentralização da tomada de decisão, a participação de diferentes atores e a inserção da variável ambiental. No entanto, por ser enquadrado na tipologia de plano, não passa por uma avaliação de impacto ambiental.

Devido à fragmentação dos órgãos técnicos de decisão referentes às questões ambientais, muitas ações que possuem um caráter sinérgico não são avaliadas, o que, segundo 
João (2007), dificulta o gerenciamento pelo poder público dos impactos cumulativos das ações de desenvolvimento.

Esta problemática vem sendo tratada pelos países da comunidade européia por meio da Avaliação Ambiental Estratégica, instrumento desenvolvido para inserir a variável ambiental no processo de decisão de políticas, planos e programas, regulamentados pela Diretiva Européia 2001/42. Este instrumento de política propõe procedimentos a serem adotados a fim de estimular a identificação dos atores envolvidos, para que sejam motivados a participar, a fim de debater os possíveis conflitos de interesses existentes, na busca por decisões representativas para a sociedade (KARSTENS et al., 2007).

De acordo com Fabbro Neto \& Souza (2009), as possíveis ligações entre a AAE e o Estatuto da Cidade permitem que a componente ambiental seja considerada durante as ações de planejamento municipal. As possíveis contribuições da realização de uma AAE para o processo de elaboração e revisão do Plano Diretor Municipal são avaliadas nesta pesquisa, procurando identificar a possibilidade de integração dos aspectos urbano e rural do território municipal, as possíveis influências desta integração sobre a tomada de decisões estratégicas e sua articulação com os diversos setores envolvidos no uso e ocupação do solo em São Carlos.

\section{OBJETIVOS}

\subsection{OBJETIVO GERAL}

Identificar as contribuições da aplicação da Avaliação Ambiental Estratégica para o planejamento de uso e ocupação do solo municipal.

\subsection{OBJETIVO ESPECÍFICO}

Verificar as possibilidades de aplicação e possíveis contribuições da AAE para o Plano Diretor Municipal, tomando como estudo de caso o município de São Carlos-SP.

Identificação de estudos de caso da experiência internacional da aplicação da AAE para o planejamento de uso e ocupação do solo municipal.

Propor uma sistematização dos instrumentos ambientais aplicados para o planejamento de uso e ocupação do solo municipal. 


\section{METODOLOGIA}

A etapa da revisão bibliográfica da presente pesquisa foi realizada em livros, teses, dissertações, artigos publicados em periódicos nacionais e internacionais, consulta a anais de congressos, relatórios técnicos de estudos ambientais, legislações e regulamentações incidentes no país.

O levantamento da revisão bibliográfica foi realizado em bases de dados digitais, como páginas web de revistas internacionais disponibilizados pelo portal da Capes - as bases de dados Web of Science, Science Direc e Scopus da editora Elsevier - e também por visitas a bibliotecas de universidades para a consulta dos materiais disponíveis. Os temas-chave pesquisados foram:

- Avaliação Ambiental Estratégica;

- Planos de Uso e Ocupação do Solo em âmbito local; e

- Plano Diretor Municipal.

A partir do arcabouço teórico-conceitual levantado pela revisão bibliográfica, a pesquisa foi realizada em diferentes etapas seqüenciais apresentadas a seguir:

\section{$1^{0}$. Passo: Identificação das contribuições, procedimentos e experiências internacionais}

O contexto da Avaliação Ambiental Estratégica foi levantado por meio de um estudo sobre as contribuições de sua realização, os procedimentos que caracterizam sua prática e experiências de aplicação deste instrumento. A Diretiva Européia 2001/42/EC (EU, 2001) e o Protocolo da Comunidade Européia de 2003 são utilizados internacionalmente como referências metodológicas do conteúdo mínimo da AAE, uma vez que são instrumentos regulamentados para servir de orientação para diferentes países.

\section{Passo: Caracterização das formas e etapas pelas práticas de AAE}

O levantamento realizado na bibliografia internacional sobre algumas das experiências práticas da AAE para planos de uso e ocupação do solo serviram para ilustrar a eficiência por meio dos resultados das aplicações recorrentes. Os modelos de realização dos estudos, as formas de participação existentes e as etapas que o configuram e que viabilizam sua aplicação foram caracterizadas para o entendimento das potencialidades do instrumento no apoio à tomada de decisão. 


\section{$3^{\circ}$. Passo: Seleção de relatórios de AAE para análise de conteúdo}

Dois relatórios de AAE de planos de uso e ocupação do solo foram selecionados para a análise dos conteúdos abordados. O relatório da Avaliação Ambiental Estratégica desenvolvida para o Plano Diretor de Monção, em Portugal, foi acessado por meio da Câmara Municipal (CMM, 2008). O relatório da Avaliação Ambiental Estratégica desenvolvida para o Planejamento de Uso e Ocupação do Solo de Mid Devon, na Inglaterra, foi acessado por meio do Conselho do Distrito de Mid Devon (MDDC, 2006). A escolha dos países foi pautada pelo fato destes países serem considerado centros de referência de Avaliação Ambiental Estratégica pela presença de pesquisas teóricas e experiências práticas de aplicação.

\section{$4^{\circ}$. Passo: Identificação das etapas do Plano Diretor Municipal}

O processo de elaboração do Plano Diretor Municipal foi analisado pelas orientações que partem do nível federal ao nível municipal, referentes à forma como deve ser conduzido o processo e elaboração do produto final, ou seja, o Plano Diretor aprovado pela Câmara Municipal e transformado em Lei Municipal. As determinações presentes na Constituição Federal do Brasil (CF, 1988), no Estatuto da Cidade (LEI FEDERAL 10.257/01) e no Plano Diretor Municipal foram estudadas para a contextualização da prática adotada no município de São Carlos.

\section{Passo: Cruzamento da AAE com o Plano Diretor Municipal como estudo de caso}

As informações das etapas anteriores serviram de base para uma reflexão em termos de planejamento municipal de São Carlos, a fim de cruzar as fragilidades e potencialidades da AAE e orientar sua aplicação no Plano Diretor Municipal, com a aproximação dos objetivos, metas e escopo que pertençam ao contexto local e também se assemelhem às experiências de êxito anteriormente estudadas.

Informações sobre o município de São Carlos foram buscadas no trabalho de graduação em Arquitetura e Urbanismo realizado por Fabbro Neto (2004) na Escola de Engenharia de São Carlos - Universidade de São Paulo, na 1 ${ }^{a}$. Conferência da Cidade de São Carlos para apoiar o processo de elaboração do Plano Diretor (PMSC, 2003) e na $4^{\mathrm{a}}$. Conferência da Cidade de São Carlos para iniciar o processo de Revisão do Plano Diretor (PMSC, 2009), e pelas informações disponibilizadas na página eletrônica da Prefeitura do Município de São Carlos (http://www.saocarlos.sp.gov.br/index.php/utilidade-publica/planodiretor.html, acessado em 2009). 
O conteúdo do Plano Diretor Municipal de São Carlos - PDMSC - foi confrontado com o diagnóstico atual do desenvolvimento do território e o contexto ambiental em que se insere o município, caracterizado pelo estudo das Bacias Hidrográficas Tietê-Jacaré e MogiGuaçu (DAEE, 2007). O histórico do crescimento urbano foi utilizado para viabilizar a identificação das tendências de crescimento, seguido da avaliação sobre a maneira que o PDMSC lida com estas questões.

\section{6$^{\circ}$. Passo: Verificação da aplicação da AAE com os procedimentos do Estatuto da} Cidade

As possíveis contribuições da realização da AAE para planos municipais de uso e ocupação do solo, assim como o conteúdo e a forma de elaboração do PDMSC foram comparados com o conteúdo dos temas abordados e a forma de elaboração dos relatórios de AAE realizadas em Monção e Mid Devon. Desse modo foi possível identificar as divergências e semelhanças entre o conteúdo dos temas abordados, os modos de interpretação destes temas e as relações estabelecidas entre eles.

Foi então realizada uma proposta de aplicação da AAE frente aos procedimentos regulamentados pelo Estatuto da Cidade, além de um prognóstico das possíveis contribuições da aplicação de AAE se realizada para o Plano Diretor Municipal de São Carlos.

\section{$7^{0}$. Passo: Sistematização dos instrumentos ambientais aplicados para o planejamento de uso e ocupação do solo no município de São Carlos}

A partir dos resultados analisados e das discussões decorrentes da análise, foram apontadas algumas considerações para o aprimoramento do modelo de planejamento territorial de uso e ocupação do solo do município de São Carlos, representado graficamente pela Figura 23 no Capítulo 7.1. 


\section{AVALIAÇÃO DE IMPACTO AMBIENTAL}

Para Coelho (2004), a compreensão de impactos ambientais como processo depende, sobretudo, de se compreender a história não-linear de sua produção, o modelo de uso e ocupação do solo e os padrões internos de diferenciação. É preciso compreender que as cidades são influenciadas por uma dinâmica internacional que ultrapassa suas fronteiras. As medidas de minimização de impactos ambientais têm que ser pensadas em uma escala de ação ampla, que abarque de forma integrada a cidade, seu espaço circundante imediato e os mais distantes.

Segundo Burgess et al. (1997), é necessário reconhecer que os problemas ambientais exigem uma responsabilidade simultânea do nível local, da cidade e da região. Neste sentido, ações de planejamento municipal envolvem o território municipal como um todo, considerando as interações entre a área urbana e o meio rural para a análise ambiental. De acordo com Sánchez (2006), é no momento da análise da viabilidade ambiental que os diferentes fatores serão contemplados, para que a sua apropriação esteja de acordo com as premissas de um desenvolvimento sustentável.

A definição da viabilidade ambiental está entre os objetivos da Avaliação de Impacto Ambiental - AIA, sendo incorporada no Brasil pela Lei da Política Nacional do Meio Ambiente - Lei ${ }^{\circ}$ 6.938/81, como instrumento da Política Nacional de Meio Ambiente. A AIA aplicada atualmente no país abrange a avaliação das decisões que antecedem as instalações de empreendimentos com potencial de significativo impacto ambiental durante processo de licenciamento ambiental, por meio da elaboração de Estudo de Impacto Ambiental - EIA e Relatório de Impacto Ambiental - RIMA, conforme concebido pela Resolução do Conselho Nacional de Meio Ambiente - CONAMA 01/86. Para Souza (2000), a AIA no Brasil pode ser vista em muitos casos como um processo técnico e burocrático, não produzindo os efeitos desejados em termos ambientais nem atingindo seus objetivos, o que resultaria na perda de sua credibilidade tanto política como social.

De acordo com Alshuwaikhat (2004) e o Ministério Público Federal - MPF (2004), algumas das mais frequentes críticas ao EIA estão principalmente nos problemas causados nas primeiras etapas dos procedimentos aplicados, particularmente durante o diagnóstico ambiental. As falhas das primeiras etapas influenciam as etapas posteriores, sendo que a mitigação de impacto e sua compensação são direcionadas sobre as definições prévias realizadas durante o diagnóstico ambiental da área de influência do projeto. Não há referências sobre a eficiência das medidas mitigadoras e sobre o desempenho do 
monitoramento ambiental das áreas de influência indireta durante a operação do empreendimento.

Para João (2007), o EIA não considera adequadamente os impactos cumulativos causados por uma série de projetos. A participação popular somente durante as audiências públicas limita a integração das demandas sociais, com pequenas considerações das diferenças na percepção ambiental (ALSHUWAIKHAT, 2004).

\subsection{AVALIAÇÃO AMBIENTAL ESTRATÉGICA}

A Avaliação Ambiental Estratégica - AAE surge no intuito de aprimorar as técnicas de AIA e permitir que a variável ambiental seja incorporada nos processo de tomada de decisão que antecedem as ações de empreendimento. Para Partidário (2002), dentro do conceito amplo de AIA, a AAE é um instrumento para gerenciar os diferentes interesses dos atores envolvidos, configurado por uma prática recente, que influencia os investimentos e estratégias de ações apoiadas em políticas, planos e programas - PPPs de governo. Desta maneira, pode oferecer um escopo das prioridades sob o enfoque das conseqüências ambientais, atuando de maneira prévia à tomada de decisão e direcionando para um desenvolvimento mais sustentável.

Para Therivel \& Ross (2007), sendo a análise da viabilidade ambiental realizada exclusivamente no nível do projeto, como acontece atualmente no Brasil, alguns impactos identificados podem não justificar a sua reprovação. A maioria dos efeitos cumulativos exige ações cumulativas como a interação de ações pulverizadas, das autoridades locais ou federais. Segundo João (2007), a somatória de impactos mínimos isolados pode se transformar num grande problema, e por mais insignificantes que aparentem se deve buscar a mitigação dos impactos.

A avaliação dos impactos cumulativos também permite um aprofundamento de medidas administrativas sobre projetos, etapas, perspectivas positivas de contribuição e criação de regras para desenvolvimento de projetos individuais. Segundo Partidário (2002), estão incluídos como âmbitos de aplicação o processo de privatização, planos plurianuais de investimento, propostas de legislação e regulamentação, políticas internacionais e setoriais, planejamento físico de uso do solo e planejamento dos recursos hídricos. 
Segundo Partidário (2002), a AAE passa a constituir um processo sequencial, que se denomina avaliação em cascata, na qual as propostas de desenvolvimento seriam então analisadas em outras escalas de ações, não se limitando ao nível do projeto, como exemplificado na Figura 1.

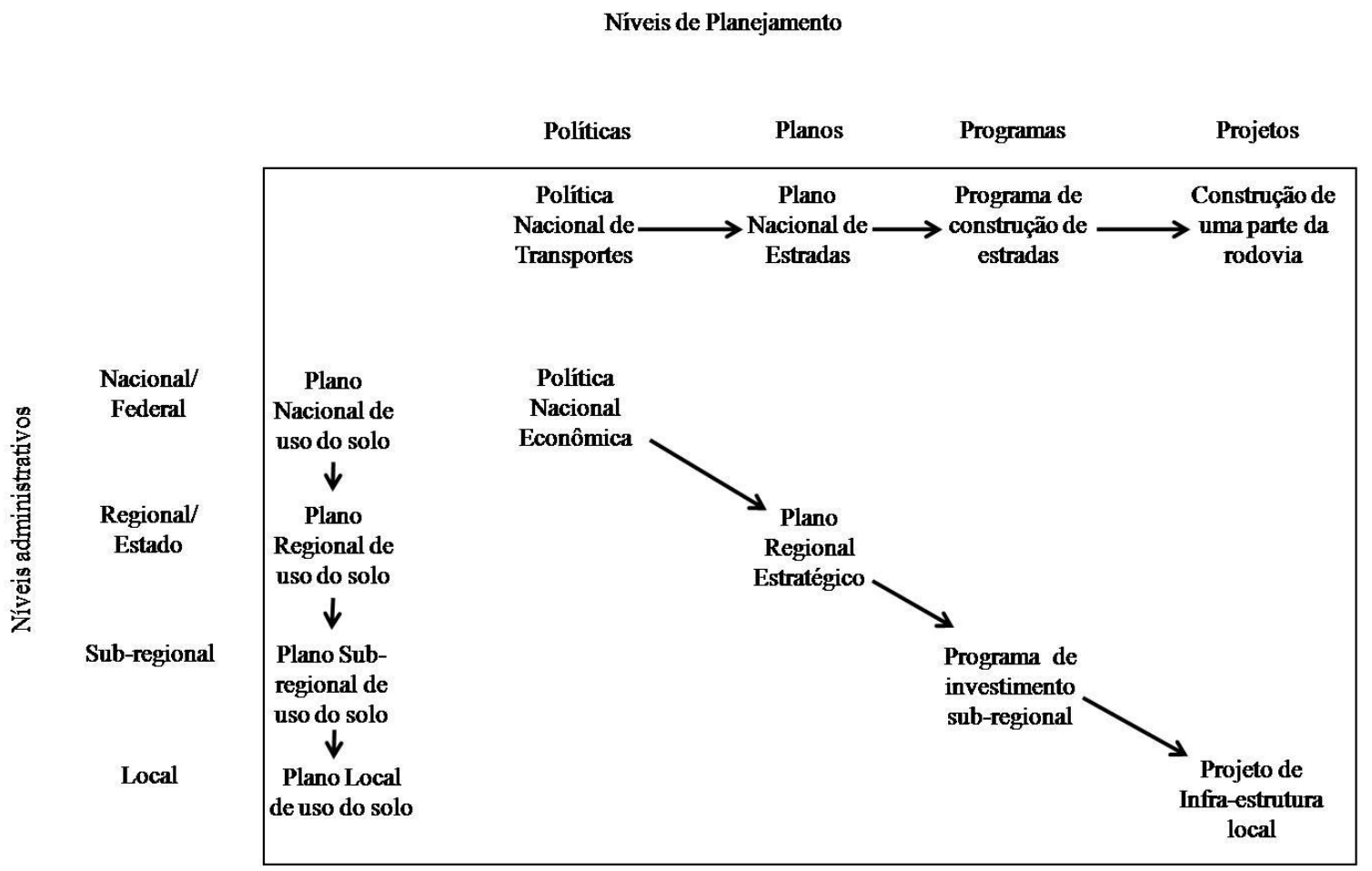

Figura 1 - Avaliação de Impactos Ambientais em cascata (adaptado de WOOD \& DEJEDDOUR, apud THERIVEL, 2004)

No exemplo da Figura 1 são apresentadas as relações entre planejamento de uso e ocupação do solo em diferentes níveis de governo junto ao setor de transportes, o qual é gerenciado por diferentes instrumentos, e ainda mostra como ações de planejamento econômico são utilizadas para integrar os dois outros setores em questão. Neste caso, a formulação de políticas é atribuída ao nível federal, que apresenta como consequiência a formulação de planos de ação regional, sub-regional e local. Estes planos, por sua vez, são implementados na forma de um programa de construção de estradas, materializado no projeto de construção de uma nova rodovia, a qual interfere nas condições de infraestrutura e no uso e ocupação de solo local. A possibilidade de inserção da componente ambiental nos primeiros estágios de planejamento permite que as futuras ações já contemplem, desde a sua gênese, a variável ambiental. 
Segundo Sadler \& Verheem (1996), os planos aplicáveis à AAE são os preparados ou adotados pelas autoridades, que requerem uma base legislativa, normas administrativas ou regulatórias, além de possuírem um significativo impacto ambiental e se distribuírem por uma rede de trabalho a ser desenvolvida por consenso de projetos listados.

Segundo Partidário (2002), a experiência do Banco Mundial revela que a avaliação ambiental setorial é particularmente útil na análise de alternativas de investimentos, alterações de políticas setoriais, capacidades institucionais e requisitos para o fortalecimento da gestão ambiental de projetos diferentes ou de um número menor de projetos semelhantes.

De acordo com Therivel (2004), a estratégia de ação pode ser alterada de acordo com o resultado da AAE, propondo-se então diferentes objetivos e alternativas diversas para alcançar estes objetivos, além de diferentes maneiras de implementá-las, como apresentado pela Figura 2. O caráter prévio é focado para garantir as possíveis alternativas e modificações nas estratégias de ação.

$\mathrm{Na}$ Figura 2, a inserção das etapas da AAE na estrutura do processo decisório permite o vínculo com a variável ambiental. As setas apresentadas sinalizam o sentido da agregação da informação, e de como estes dados contribuem para as etapas posteriores. É importante destacar o potencial de contribuição mútua entre as informações geradas na tomada de decisão estratégica e na AAE, como durante as etapas de definição de formas alternativas de alcançar a resolução dos problemas para a tomada de decisão, que coincide com a identificação de alternativas mais sustentáveis pela AAE. Outro exemplo de mútua colaboração está na etapa de refinamento das alternativas escolhidas da tomada de decisão estratégia, que influencia e é influenciada pela etapa de mitigação de impactos das alternativas escolhidas durante a realização da AAE.

A AAE deve ajudar a identificar a melhor opção para a estratégia de ação, selecionando e analisando diferentes opções de planos, encontrando demandas, minimizando danos e oferecendo opções para administrar essas possibilidades. Essencialmente, a AAE ajudaria a expandir o foco do tomador de decisão para incluir questões que estão além de sua área principal, como a sustentabilidade ambiental, por exemplo.

O público pode ajudar a estabelecer os objetivos, metas e indicadores e tornar as informações mais compreensíveis, tornando as questões ambientais mais próximas da realidade local e contribuindo para a identificação de opções inovadoras, sustentáveis e politicamente aceitáveis, além se selecionar alternativas e medidas mitigadoras, garantindo a eficiência na implementação das ações. 
Tomada de decisão estratégica

AAE

Identificar objetivos da ação estratégica

Identificar objetivos e indicadores de AAE; Incluir questões ambientais e de sustentabilidade.

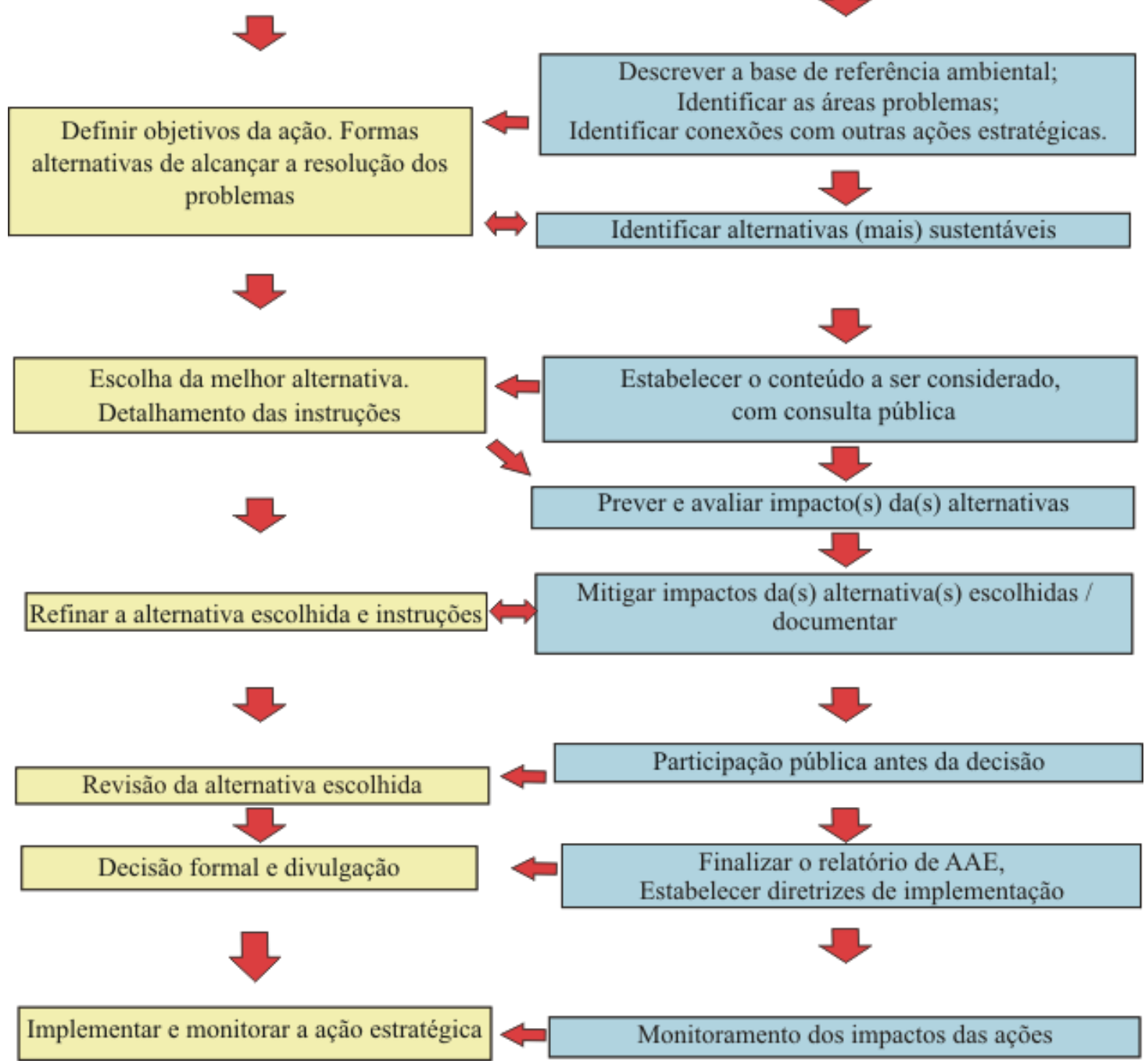

Figura 2 - Ligações entre AAE e tomada de decisão estratégica (baseado THERIVEL apud OLIVEIRA, 2008)

O processo da AAE funciona melhor quando há uma ampla integração de interesses e propostas. A AAE pode ser elaborada simultaneamente aos planos em andamento, fazendo com que deste modo as propostas partam de uma gênese sustentável, influenciando-se umas às outras, num fluxo contínuo. Geralmente a integração da AAE com outros procedimentos administrativos fortalece a coerência e eficiência de ambos os procedimentos. 


\subsubsection{ETAPAS SEQUENCIAIS DA AAE}

A Diretiva da União Européia 2001/42/EC (EU 2001) e o Protocolo da Comunidade Européia de 2003 são instrumentos formulados para servirem de apoio na elaboração da AAE, os quais definem o conteúdo mínimo e uma metodologia inicial a ser aplicada. Segundo Partidário (2002), a elaboração de uma AAE deve seguir procedimentos técnicos com as seguintes etapas sequenciais básicas:

$1^{\text {a }}$ Seleção de propostas de decisão estratégica (screening);

$2^{\text {a }}$ Estabelecimento dos prazos (timing);

$3^{\text {a }}$ Definição do conteúdo da avaliação (scoping);

$4^{\text {a }}$ Avaliação dos impactos estratégicos;

$5^{\mathrm{a}}$ Documentação e informação;

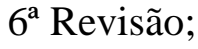

$7^{\mathrm{a}}$ Decisão e

$8^{\text {a }}$ Acompanhamento da implementação da decisão estratégica.

A primeira etapa para a realização da AAE deve ser feita pela seleção de propostas de decisões estratégicas - chamada de screening, seguida da segunda etapa, caracterizada pelo estabelecimento de prazos para sua realização - chamada de timing.

A terceira etapa é a delimitação do escopo dos estudos - chamada de scoping, que se inicia com a definição de objetivos e metas. Esta etapa vai definir os dados e informações a serem levantados e os indicadores passíveis de serem selecionados. A mesma etapa influência também em quais previsões de impactos serão feitas e o sistema de monitoramento estabelecido, conforme ilustrado na Figura 3. Assim será possível identificar os atores envolvidos - os chamados stakeholders, que deverão ser estimulados a participar da elaboração dos estudos o mais breve possível. 


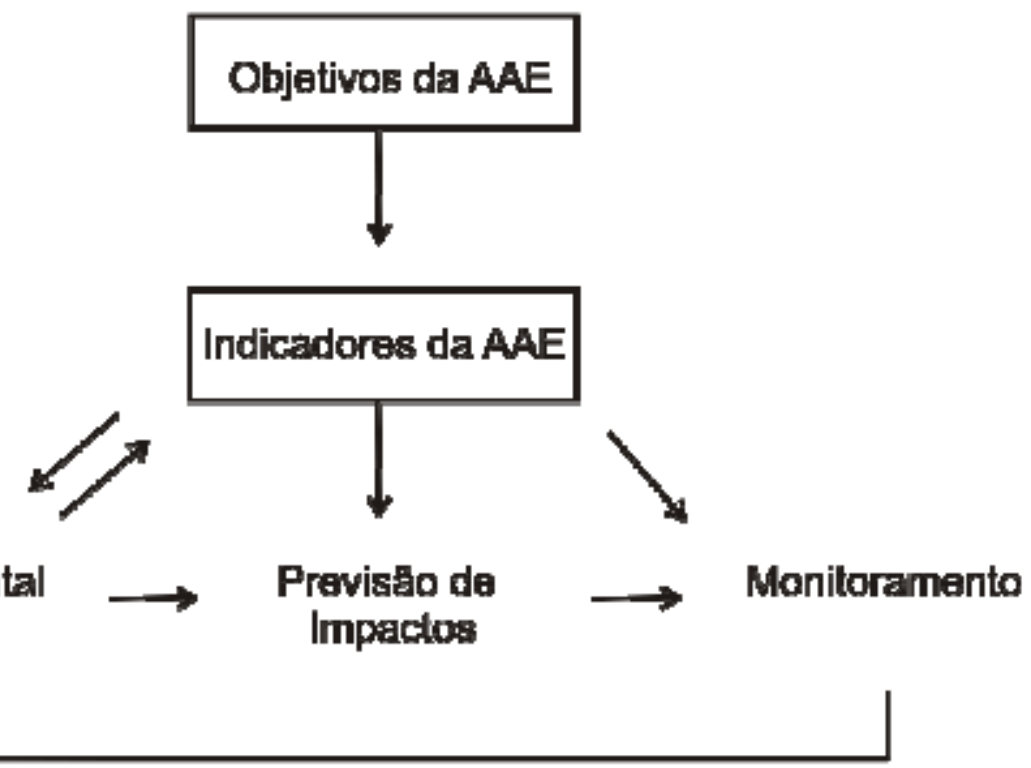

Figura 3 - Ligações entre objetivos, indicadores e outras etapas da AAE. (adaptado de THERIVEL apud LEMOS, 2007)

O escopo vai determinar a escala das informações ambientais, que devem ser necessariamente definidas. Para João (2007), a escala significa a extensão da área, a quantidade de detalhes utilizados e a dimensão temporal. Segundo Karstens et al. (2007), ela ainda dispõe limites nos tipos de problemas a serem elencados, as soluções a serem encontradas e os impactos a serem avaliados. A escolha do que será incluído ou deixado de fora da análise pode beneficiar, intencionalmente ou não, alguns atores.

A definição da escala envolve a identificação de cada limite, através do diagnóstico ambiental da área, o que requer a previsão de efeitos da estratégia, incluindo a comparação do cenário futuro sem a implementação da ação, contraposto com a estratégia defendida. A AAE deve garantir que a estratégia adotada não exceda a capacidade de suporte do meio, evitando os impactos irreversíveis e contribuindo para encontrar outras maneiras de manipulá-los. Também é necessário definir os efeitos significativos e as possibilidades de exceder tais limites.

A escala espacial permite a representação dos mais relevantes processos ambientais e indicações de uso do solo. Segundo Geneletti et al. (2007), a AAE precisa gerar informações relevantes que sejam viáveis de serem frequentemente atualizadas para os tomadores de decisão, o que implica em fundamentar o mapeamento em escala adequada. No futuro isso 
pode reduzir significativamente o tempo e o custo envolvido nos instrumentos de decisão (GENELETTI et al., 2007).

A seleção apropriada de indicadores está fortemente influenciada pelo tipo de informação disponível no momento e aqueles que serão úteis para a prática futura. Isso se aproxima da coleta de dados de bases de referência - as chamadas baselines. As bases de referência contêm informações sobre o ambiente prévio à implementação dos planos de gestão. O desempenho provém da informação do estado do ambiente após a implementação do plano, através do desenvolvimento dos indicadores ambientais adotados. A precisão da AAE depende de mudanças ambientais mensuráveis: somente informações contidas tanto nas bases de referência como na futura situação mensurável do ambiente serão corretamente ilustradas nos efeitos de implementação do plano ambiental.

A partir do diagnóstico realizado é possível estipular a hierarquia de questões a serem solucionadas e as conseqüentes ações da implementação da proposta, chamadas de tiering. Deste modo será mais ágil a elaboração de PPPs a serem tomadas para a conquista dos objetivos e a previsão dos cenários provenientes das alternativas possíveis.

A quarta etapa é a denominada previsão de impactos, com a determinação do tipo e da magnitude dos impactos ambientais esperados para a implementação dos objetivos, a partir da análise das bases de referência. De acordo com João (2007), na AAE a diversidade de impactos em geral é ampla, comparado com aqueles que se obtém na AIA de projetos. Isso ocorre em função do grande número e da enorme variedade de dados analisados, porém o nível de detalhamento dos impactos na AAE normalmente é menor do que nos EIAs.

A previsão de impactos deve estar claramente relacionada aos principais problemas ambientais identificados na fase de elaboração do conteúdo a ser analisado, bem como às condições do meio ambiente da área. A situação atual e a tendência futura de um componente ambiental, relativo à sua meta esperada, ajudam a determinar como esse problema pode ser administrado e pode sugerir medidas mitigadoras. As tendências de alteração ocorridas no passado podem ajudar na avaliação dos planejadores com relação ao futuro esperado, frisando-se também que a reversibilidade das tendências também é um fator importante a ser considerado.

A quinta etapa é a elaboração do relatório da AAE. O relatório ambiental deve ser preparado para a identificação, descrição e avaliação da forma como os efeitos significativos no ambiente se manifestarão através da implementação da proposta, com o registro das alternativas viáveis de acordo com os objetivos e o diagnóstico do meio em questão. $\mathrm{O}$ relatório deve ser apresentado ao público num tempo hábil para que sejam possíveis 
modificações na descrição da área e das ações estratégicas. O processo transparente é fundamental para o sucesso da metodologia. (DALAL-CLAYTON \& BASS, 2002).

O impacto dessas informações está diretamente ligado a quem as prepara e dissemina, e ao veículo utilizado para a divulgação. O diálogo traz familiaridade, credibilidade e acessibilidade. Outra chave está na consistência e regularidade. Sendo estas asseguradas, atribui-se confiança às informações e as ações serão apropriadas, notificadas e respondidas (DALAL-CLAYTON \& BASS, 2002).

A sexta etapa é a revisão do resultado dos procedimentos realizados, o que inclui a consulta pública. O envolvimento popular na tomada de decisão durante a realização da AAE traz vantagens na estrutura local, no conhecimento e pesquisa, propiciando liderança com maior sociabilidade e aceitação política das decisões, além de estimular a apropriação das decisões e a transformar as estratégias de ação mais acessíveis na resolução de conflitos internos e na busca pela garantia de inserção dos pontos de vistas populares na decisão tomada, contemplando as diferentes percepções ambientais.

A sétima etapa é a tomada de decisão estratégica, caracterizada por ser uma responsabilidade política. A AAE se propõe a expandir o foco do tomador de decisão para incluir questões que estão além de sua área principal, se aproximando da sustentabilidade ambiental, como apresentado na Figura 4. A AAE deve ajudar a identificar a melhor opção para a estratégia de ação, identificando e analisando diferentes alternativas, encontrando demandas, minimizando danos e oferecendo opções para administrar essas possibilidades.

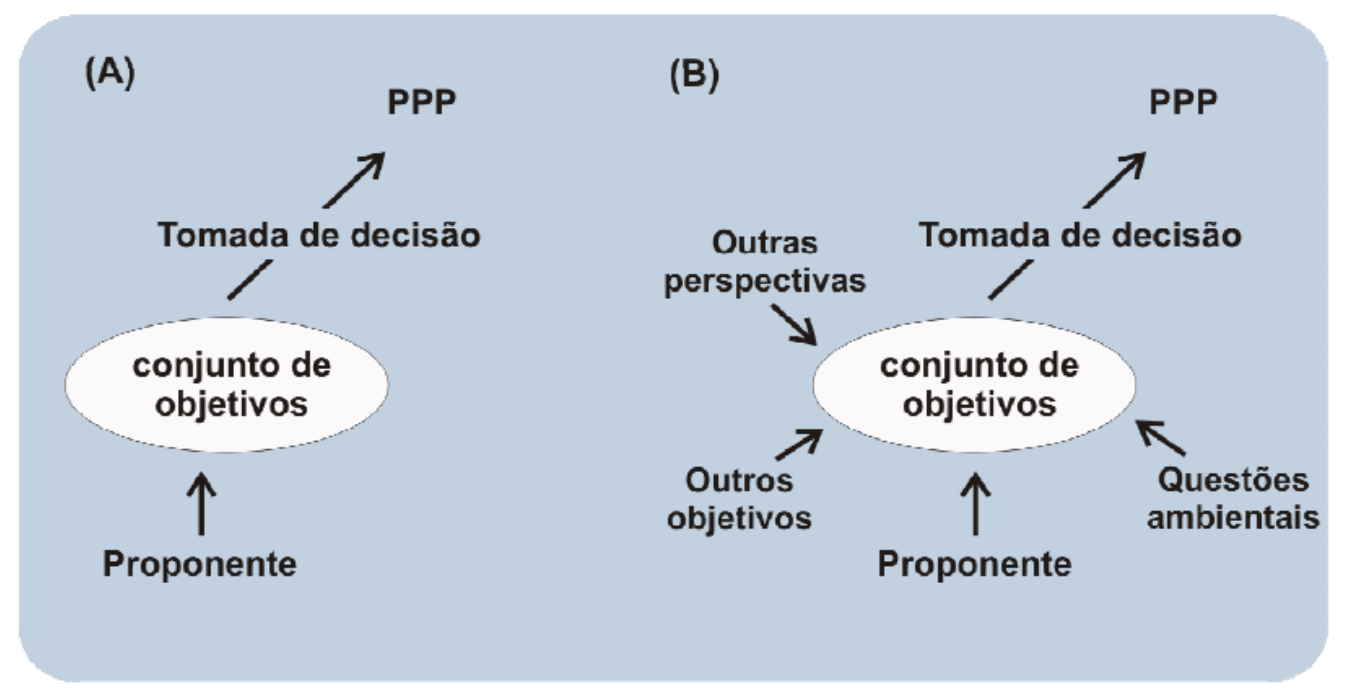

Figura 4 - Tomada de decisão sem (A) e com (B) a AAE. (Adaptado de BROWN \& THERIVEL apud LEMOS, 2007) 
A oitava etapa é o acompanhamento da implementação da decisão estratégica. Os responsáveis pela elaboração da AAE devem propor um modelo de monitoramento, o qual permite que os atuais impactos da estratégia sejam testados contra as previsões, os maiores problemas identificados, e as bases de referência atualizadas para as futuras ações. Isso ajuda a garantir que as medidas mitigadoras propostas sejam aplicadas, e que impactos não previstos surpreendam as ações de planejamento.

De acordo Dalal-Clayton \& Bass (2002), governos não podem assumir a posição de monitoramento e guiar todas as ações das organizações, dos setores privados e dos cidadãos nas sociedades complexas. Para que a responsabilidade do monitoramento possa ser compartilhada é necessária a documentação de todo o processo, na forma de um relatório ambiental.

Segundo Dalal-Clayton \& Sadler (2005), as áreas de uso do solo e transporte estão entre os setores que mais possuem experiências de aplicação AAE. Para o planejamento de uso e ocupação do solo, a AAE proporciona um gerenciamento participativo das ações, envolvendo a população e as associações representativas de diferentes setores da comunidade que se relacionam com o crescimento das cidades no processo de tomada de decisão, durante as etapas de planejamento, execução e monitoramento, visando à preservação dos recursos do meio rural e urbano, integrando a qualidade ambiental com as demandas sociais.

De acordo com Partidário (2002), Therivel (2004), Glasson et al. (2005), a contribuição para um processo de sustentabilidade, a geração de um contexto de decisão mais amplo e integrado com a proteção ambiental constituem benefícios notáveis da AAE em sua capacidade de instrumento de política ambiental. Em termos gerais, os principais atributos da AAE estão no fortalecimento da AIA, na identificação dos impactos cumulativos e conseqüentes efeitos de longo prazo, conduzindo para a melhoria da qualidade ambiental.

\subsection{PRÁticas de AAE PARA PLANOS DE USO E OCUPAÇÃO DO SOLO}

A avaliação de algumas experiências de aplicação da AAE para planos de uso e ocupação do solo permite que sejam identificadas as vantagens de aplicação deste instrumento para a gestão do território. Os processos de elaboração da AAE e sua integração com os processos de planejamento de uso e ocupação do solo foram levantados nas experiências realizadas em diferentes países, para subsidiar a comparação com o processo de planejamento do município de São Carlos, conforme descrito a seguir: 


\section{- Hertfordshire, Inglaterra}

O Reino Unido possui Conselhos regionais para estabelecer normas e orientações referentes às ações de planejamento. $O$ Conselho da região de Hertfordshire incorporou os princípios do desenvolvimento sustentável no seu plano estrutural de uso do solo local por meio da AAE. Esta estabeleceu objetivos de sustentabilidade, a avaliação de planos, alternativas, estratégias e políticas baseadas nestes objetivos. Neste sentido, para Rumble \& Therivel (apud SHEPHERD \& ORTOLANO, 1996), a intenção de uma AAE é auxiliar a incorporação dos princípios da sustentabilidade na estrutura de planejamento.

Assim, em 1993 o departamento de planejamento do conselho da região de Hertfordshire decidiu preparar uma nova estrutura de plano, ao invés de modificar a antiga, e usou a sustentabilidade como ponto-chave inicial. O conselho regional realizou consultas para produzir uma estratégia ambiental, que procurou ligar a AAE com a estrutura do plano. Discussões com o público ajudaram no estabelecimento das metas de sustentabilidade, as quais incluíram a redução, de modo geral, da demanda por recursos, o aumento do reuso e reciclagem de recursos e a melhoria da qualidade de vida, conforme preconizado por Rumble \& Therivel (apud SHEPHERD \& ORTOLANO, 1996).

As metas de sustentabilidade procuraram uma estrutura para avaliar decisões, políticas e programas na estrutura do plano. Tais metas e os objetivos estruturais do plano foram publicados 1994 e utilizados no programa de consulta pública, na qual um índice superior a $1 \%$ da população de Hertfordshire foi contatada, evidenciando, portanto o alto apoio popular da estrutura de planejamento (RUMBLE \& THERIVEL, apud SHEPHERD \& ORTOLANO, 1996).

\section{- Oldham, Inglaterra}

Fischer (2007) descreveu diferentes experiências de aplicação de AAE para gestão de uso de solo, como a avaliação de planos de uso e ocupação do solo municipal, além de planos de paisagem e de planejamento urbano. Em meados da década de 1990, a experiência de aplicação da AAE para plano de uso e ocupação do solo de Oldham foi preparada em paralelo à elaboração de outras políticas de planejamento, posteriormente integradas por meio de exercícios como a elaboração de matrizes de compatibilidade, sendo que os objetivos dos planos foram confrontados com as metas de sustentabilidade através da avaliação dos impactos ambientais 
prováveis pela implantação do plano analisado. A AAE contribuiu para a mudança dos pontos de vistas dos atores envolvidos ao propiciar o diálogo e a argumentação pela defesa dos diferentes interesses.

\section{- Weiz, Áustria}

Para a revisão do planejamento de uso e ocupação de solo entre os anos de 1997 e 1998 de Weiz também foi aplicada a AAE. Segundo Fischer (2007), o planejamento urbano do município foi revisado e 27 áreas com demandas ou potencial para novos desenvolvimentos foram identificadas. Para maior eficiência e efetividade das decisões, a revisão foi acompanhada do planejamento de uso do solo e da AAE, sob a coordenação do poder público local, com um horizonte de planejamento para 5 anos. Para cada uma das 27 áreas foram avaliados 3 cenários possíveis: uma não-ação, uma intenção da municipalidade, e uma alternativa de cunho ambiental mais forte. Os critérios ambientais e socioeconômicos foram usados para a avaliação dos diferentes usos propostos para o desenvolvimento de cada uma das áreas.

Segundo Fischer (2007), as pressões políticas e interesses dos investidores não permitiram que algumas das recomendações e os resultados da AAE fossem totalmente considerados, isto é, a decisão final não refletiu a opção de melhor qualidade ambiental. As razões para a escolha inicial das áreas deixaram de ser investigadas ou apresentadas, o que sugere que sua aplicação foi menos estratégica e mais orientada para projetos (FISCHER, 2007).

\section{- Alemanha}

Reinke (2005) realizou uma análise geral das experiências da aplicação de AAE para o planejamento de uso e ocupação do solo na Alemanha. Entre os objetivos do estudo estão à identificação da viabilidade de considerar a proteção ambiental nos planos de uso de solo, de acordo com o Código de Obras Alemão e da utilização dos conteúdos e diagnósticos dos planos de paisagem como uma base ecológica para o planejamento urbano e para a AAE. Pela natureza da conservação, o desenvolvimento urbano sustentável poderia possibilitar garantias econômicas e sociais equivalentes à utilização do uso do solo.

As áreas escolhidas para os novos assentamentos foram aquelas que apresentaram menor valor de conservação e de recursos naturais, sendo que os recursos do meio físico foram, segundo Reinke (2005), tendenciosamente 
desprivilegiados quando comparados aos recursos bióticos e visuais. Segundo o autor, os interesses pelo uso dos recursos do meio físico influenciaram a sua caracterização, de modo que fossem minimizados os impactos decorrentes. A qualidade das informações ecológicas foi afetada pela falta de atualização. Foi identificada a falta de direcionamento das pressões antrópicas nos planos de paisagem, limitando seu escopo apenas para as interações físicas e bióticas, o que inclui falta de considerações sobre o avanço da malha urbana e também a falta da internalização das considerações feitas durantes as consultas públicas.

\section{- Ketzin, Alemanha}

A AAE foi aplicada para a integração do planejamento da paisagem com o plano local de uso e ocupação de solo, entre os anos de 1995 e 1996, no município de Ketzin, em Brandenburg, Alemanha. Os planos de paisagem e seus programas são preparados em paralelo às várias outras PPPs aplicáveis. O principal objetivo deste sistema de planejamento é melhorar a qualidade ambiental através da proteção de áreas que possuem alto valor ecológico ou de beleza cênica, focando o seu desenvolvimento e otimizando partes da paisagem. Uma importante função dos planos e programas de paisagem é a identificação de áreas propícias a determinados tipos de desenvolvimento e áreas que devem ser mantidas livres. $\mathrm{O}$ fato é que os planos de uso de solo não poderiam ser aprovados sem a complementação e confirmação dos planos de paisagem (FISCHER, 2007).

A sustentabilidade para certos usos foi identificada, o que representa uma aproximação pró-ativa da AAE e a consequente consideração de suas alternativas. Diferentes opções de desenvolvimento espacial foram consideradas, com a indicação de áreas mais adequadas para o desenvolvimento. Deste modo, foram identificadas as medidas mitigadoras e designar áreas de compensação, caso existam impactos de empreendimentos que não possam ser mitigados. Com a participação durante o plano de paisagem, a divulgação das informações e discussões decorrentes preparou os stakeholders para opinar efetivamente nas decisões do planejamento de uso do solo e, conseqüentemente, a aceitação do plano de paisagem foi reforçada. Nenhuma avaliação dos efeitos sociais e econômicos foi realizada e, como consequiência, foi dificultada o estabelecimento dos desdobramentos potenciais. Mesmo assim, a experiência permitiu a geração de informações necessárias para a elaboração de termos de referência de AIA (FISCHER, 2007). 


\section{- Sollentuna e Karlskoga, Suécia}

Durante os anos de 1992-1993 um time de planejadores, especialistas ambientais e consultores - a equipe de AAE - realizaram uma AAE para o planejamento participativo de Sollentuna e Karlskoga, na Suécia. Em Sollentuna foi realizada uma AAE para a política de uso do solo referente à parte do desenvolvimento espalhado da comunidade. Em Karlskoga foi aplicado a AAE para o planejamento de uma nova linha férrea. A equipe de AAE conversou com a população e administradores públicos na busca pelo desenvolvimento sustentável. Os princípios de sustentabilidade foram utilizados para analisar os impactos ambientais e a formulação de medidas mitigadoras (ASPLUND \& HILDING-RYDEVIK, apud SHEPHERD \& ORTOLANO, 1996).

Em Sollentuna a comissão de planejamento local foi iniciada com a política para o futuro uso do solo de uma parte da cidade não desenvolvida. O processo de planejamento iniciou com o mínimo de participação da equipe de AAE. As questões chaves, incluindo as questões ambientais, foram discutidas nos primeiros encontros, mas sem a presença de especialistas da área ambiental. Houve a inserção das perguntas formuladas pelos planos alternativos na consulta do planejamento urbano. Posteriormente, o grupo de especialistas ambientais desenvolveu os critérios de sustentabilidade. No entanto, estes critérios não influenciaram significativamente a formulação das alternativas porque, em função do tempo, a consulta do planejamento do uso e ocupação do solo foi focada na defesa das propostas particulares. A integração da equipe de AAE foi pouco eficiente em função dos obstáculos durante a revisão das decisões anteriores. A AAE se tornou um relatório separado ao invés de ser uma parte integrante do planejamento participativo. O relatório de AAE foi deixado como uma escolha para valores de informação (ASPLUND \& HILDINGRYDEVIK, apud SHEPHERD \& ORTOLANO, 1996).

Em Karlskoga as lições de Sollentuna ajudaram no processo de integração da AAE, devido à constatação da importância do prévio e simultâneo início entre AAE e atividades do planejamento participativo. A equipe de AAE desenvolveu objetivos para avaliar as alternativas. Critérios de sustentabilidade não foram explicitamente definidos, mas estiveram presentes implicitamente nos objetivos da equipe (ASPLUND \& HILDING-RYDEVIK, apud SHEPHERD \& ORTOLANO, 1996).

A integração da AAE teve êxito, pois a equipe preparou um relatório individual separado com claras conexões entre AAE e o planejamento participativo. A integração 
da AAE tornou possível a melhora e a transformação de ambos os processos de planejamento e seus resultados. O processo de planejamento que usualmente focava questões técnicas foi aberto para discussões políticas de sustentabilidade. O resultado atingiu o esperado para contribuir para o desenvolvimento sustentável, e os resultados da AAE levados para os planos de desenvolvimento específicos. Nestes dois casos na Suécia, a integração da AAE com o planejamento participativo foi fortemente influenciada pelas primeiras etapas de planejamento (ASPLUND \& HILDINGRYDEVIK, apud SHEPHERD \& ORTOLANO, 1996).

\section{- Amsterdam, Holanda}

A AAE realizada para o plano de desenvolvimento de Amsterdam foi elaborada entre os anos de 1996 e 1998, enquanto não havia um procedimento formal regulamentado. Para todos os cenários foram avaliados os impactos do crescimento populacional para o desenvolvimento de áreas residenciais e de negócios, além do número de empregos avaliados. As escolhas de desenvolvimento urbano sem a aplicação da AAE costumavam ser determinadas por considerações mais econômicas (FISCHER, 2007).

As principais opções de desenvolvimento estudadas envolveram a permissão de desenvolvimento somente de áreas já dotadas de infra-estrutura, a avaliação de um avanço ilimitado, e por fim, um meio termo entre as duas opções anteriores, com a possibilidade de expansão da infraestrutura aliado às já existentes. Todas as possibilidades foram traduzidas em mapas utilizados para a previsão de impactos. Pela previsão de impactos e por meio da participação de poder público, de especialistas e da sociedade, optou-se pela opção intermediária, onde o crescimento da malha urbana não se limita à existência de infraestrutura prévia, mas também não pode avançar para qualquer lado sem um controle prévio (FISCHER, 2007).

\section{- Rotterdan e Leiden, Holanda}

No caso da aplicação da AAE para o desenvolvimento de novas áreas residenciais e de negócios em Rotterdam e Leiden, entre os anos de 1995 e 1997, o estudo foi realizado em função da escolha de áreas para o desenvolvimento destes dois municípios em conflito com a política nacional de desenvolvimento espacial e ambiental, principalmente por impactar áreas protegidas da região metropolitana de Amsterdam. Através da análise da AAE, procurou-se identificar possibilidades de 
alteração da legislação nacional para acomodar as propostas de desenvolvimento de Rotterdam e Leiden. Neste caso, optou-se por considerar não apenas aspectos ambientais, mais variáveis econômicas e aspectos sociais (FISCHER, 2007).

Os procedimentos da AAE propiciaram um aprofundamento das questões ambientais e acabaram por incentivar o poder municipal a procurar áreas que não estivessem em conflitos com a legislação nacional e a proteção da qualidade ambiental. A AAE trouxe uma melhor hierarquização das políticas em diferentes níveis decisórios - nacional, regional e local - ao avaliar as conseqüências das ações em longo prazo. O processo pode ser visto como transparente e estimulou a comunicação de diferentes órgãos governamentais e da sociedade (FISCHER, 2007).

\section{- San Joaquin, Estados Unidos da América}

A equipe da região de San Joaquin, auxiliada por consultores da área, preparou um plano geral para um período de 5 anos. O plano previu a acomodação do crescimento populacional e emprego para o ano de 2010 no âmbito das 7 cidades existentes na região. No entanto, posteriormente houve a proposição de 5 novas cidades na região, apontando para a necessidade de elaboração de um segundo plano. A projeção populacional e propostas dos empreendedores para as 5 novas cidades foram utilizadas para guiar o plano geral. As propostas dos empreendedores foram feitas independentemente dos planos dos administradores da região (SKEWES-COX, apud SHEPHERD \& ORTOLANO, 1996).

A AAE analisou os impactos, avaliou as alternativas e incluiu medidas mitigadoras. Muitos impactos não foram adequadamente avaliados na etapa de planejamento geral, o que se esperava ser direcionado para maior detalhamento nos níveis de projeto. Um plano de monitoramento foi incorporado na AAE para todas as medidas mitigadoras recomendadas. A AAE e o plano geral foram integrados desde o início. Ao final, no entanto, a AAE não garantiu que a região adotasse o plano geral de cunho ambiental mais forte. Mesmo assim, o relatório da AAE foi considerado válido para analisar futuros projetos na região (SKEWES-COX, apud SHEPHERD \& ORTOLANO, 1996).

\section{- Ottawa e Carleton, Canadá}

A AAE foi adotada pela iniciativa individual dos próprios municípios na região de Ottawa e Carleton. A municipalidade regional de Ottawa-Carleton - MROC - 
iniciou os estudos em 1994, finalizando-os em 1997 para integrar a revisão do Plano Oficial de Uso do Solo com Plano Diretor para água, esgoto e transporte. Juntos, estes planos providenciaram uma Estratégia de Desenvolvimento Regional: uma análise integrada dos futuros do uso e ocupação do solo além da infraestrutura para acomodar o crescimento para o ano de 2010. Estes estudos não utilizaram explicitamente termos técnicos, e o critério de avaliação caracterizou os princípios da sustentabilidade, derivados da visão comunitária do MROC e do guia político do governo da região (MCKINNON \& JOYNER, apud SHEPHERD \& ORTOLANO, 1996).

O processo de planejamento integrado do MROC possui duas fases distintas: estratégia e detalhamento. A fase da estratégia foi desenvolvida numa clara direção para o planejamento do uso do solo. Cenários de desenvolvimento alternativos foram sistematicamente avaliados, em oposição a um conjunto de 29 critérios relativos à sustentabilidade. Um documento integrado incluiu o cenário de desenvolvimento sugerido e as medidas de mitigação. A fase de detalhamento do estudo utilizou uma variedade de critérios para avaliar as alternativas de infraestrutura para o cenário de desenvolvimento sugerido da região (MCKINNON \& JOYNER, apud SHEPHERD \& ORTOLANO, 1996).

A estratégia de Desenvolvimento Regional e o pacote de infraestrutura passaram pela revisão das agências técnicas e da população. A documentação final incluiu projetos de infraestrutura, requerimentos que deveriam ser atendidos pelo processo de planejamento integrado, outros requerimentos para serem complementados por projetos específicos e programa de monitoramento região (MCKINNON \& JOYNER, apud SHEPHERD \& ORTOLANO, 1996).

Após a análise das experiências realizadas por diferentes países ao institucionalizar a questão ambiental no planejamento municipal por meio da AAE, se identifica que a busca pela viabilidade ambiental através de alternativas concretas está entre as questões mais relevantes das decisões de planejamento de uso do solo. De acordo com Jenks (2000), são vários os componentes com potencial para influenciar a sustentabilidade das cidades, como o tamanho, forma, densidade, processos de intensificação e descentralização, uso e ocupação do solo, organização e tipologia de construção, áreas verdes e espaços abertos.

Evidências de casos brasileiros, segundo Silva et al. (2000), demonstram que o crescimento municipal vem acontecendo o mais longe possível das áreas urbanizadas com a existência de glebas vazias, o que se torna altamente rentável para os investidores privados, já 
que cabe ao poder público a implantação de infraestrutura entre as áreas urbanizadas, provocando a posterior valorização da gleba. A falta de regulamentação adequada na escala nacional, particularmente em relação ao meio ambiente e ao gerenciamento de custos dos serviços públicos, tem enfraquecido as estruturas de poder público local e regional, e sobretudo, a participação social em geral (CARMONA, 2000).

A possibilidade para as regiões e cidades de países em desenvolvimento, de acordo com Jenks (2000), vem sendo o crescimento descontrolado, predominância do setor informal, problemas com infraestrutura inadequada, carência de serviços e degradação ambiental. De um modo geral, a profunda diferença entre os setores formais e informais, entre as regiões centrais e a periferia urbana, entre os loteamentos criados para a classe alta para os de perfis populares, colocam sérios obstáculos para o desenvolvimento sustentável.

\subsection{RELATÓRIOS DE AAE APLICADOS A PLANOS MUNICIPAIS DE USO E OCUPAÇÃO DO SOLO}

Foram selecionados dois relatórios de aplicação de AAE realizados para Planos de Uso e Ocupação do solo para analisar a estrutura e sistematização adotada em diferentes casos. Optou-se na presente pesquisa por selecionar experiências realizadas em Portugal e Inglaterra devido às importantes contribuições teóricas e reflexivas sobre AAE que estas apresentam. Dentro de cada relatório foram selecionados os temas e objetivos abordados para serem confrontados com o modelo e as questões de planejamento municipal realizado no município de São Carlos.

\subsection{1 - AAE PARA O PLANO DIRETOR MUNICIPAL DE MONÇÃO - PORTUGAL (CMM, 2008)}

Os Planos de Ordenamento Territorial - POT - desenvolvidos em Portugal estabelecem o regime de uso do solo, definindo modelos de evolução da ocupação humana e da organização de redes e sistemas urbanos, estabelecendo parâmetros de aproveitamento do solo e de garantia de qualidade ambiental. Os Planos Diretores Municipais - PDMs - estão incluídos no grupo dos POT e dão suporte ao uso e ocupação do solo, à política municipal de ordenamento do território e às demais políticas urbanas, contribuindo para estabelecer um modelo de organização espacial do território. 
Assim como no Brasil, o PDM é considerado um instrumento de referência para a elaboração dos demais planos municipais de ordenamento do território e para o estabelecimento de programas de ação, bem como para o desenvolvimento das intervenções setoriais da administração do Estado no município, concretizando o princípio da coordenação das respectivas estratégias de ordenamento territorial.

De acordo com o artigo 5..$^{\circ}$ da Diretiva 2001/42/CE, sempre que seja necessário proceder a uma avaliação ambiental, deve ser elaborado um relatório ambiental no qual há necessidade de identificação, descrição e avaliação dos eventuais efeitos significativos no ambiente resultantes da aplicação do plano ou do programa, além da apresentação das suas alternativas que considerem os objetivos e o âmbito de aplicação territorial. Relativo à proposta de revisão do PDM de Monção, a equipe responsável pela elaboração da AAE, somado aos setores da administração pública, iniciativa privada e demais atores afetados, identificaram os seguintes cenários:

\section{- Cenário 1 - Requalificação urbana e rede de equipamentos.}

Com a requalificação urbana e rede de equipamentos se pretendia melhorar a imagem e a vivência urbana, e reforçar, qualificar e estruturar as áreas urbanas consolidadas. Esta opção estratégica englobou também a criação de uma rede de equipamentos e infraestrutura que melhorem a qualidade de vida e a atratividade da cidade.

\section{- Cenário 2 - Reorganização da estrutura viária.}

Objetivava dar uma nova organização e requalificação principalmente em termos de comodidade de deslocamento e segurança às diversas vias existentes. Esta opção tinha como vantagem diminuir a pressão no núcleo central referentes ao uso da infraestrutura dsiponível, promover o desvio do trânsito pesado dos eixos de uso doméstico e melhorar os acessos às áreas fundamentais de vivência urbana.

- Cenário 3 - Reforçar a atratividade da cidade, valorizando o patrimônio natural e afirmando a memória histórica.

Objetivava fazer uma grande afirmação da área ribeirinha, dotando-a de elementos atrativos que valorizassem o bem-estar e o lazer das populações. Esta opção permitiria criar um suporte à realização de atividades turísticas, considerando as vertentes do turismo ecológico. 
- Cenário 4 - Aumentar a competitividade econômica e investimento empresarial.

Esta opção estratégica teve como referencial o aumento da atratividade para a instalação de empresas, criando condições de infraestrutura do território que permitiriam o desenvolvimento de diversas atividades econômicas. Este contexto acarretou novas dinâmicas que, direta ou indiretamente, exerciam pressões na infraestrutura de suporte referentes às vias de comunicação, e na organização dos espaços urbanos, industriais, de cultura, recreio e lazer.

A avaliação ambiental foi pautada pela identificação dos impactos ambientais que subsidiaram a formulação dos Fatores Críticos de Decisão - FCD. A metodologia adotada para definir os FCDs envolveu a identificação dos setores da administração pública, iniciativa privada e demais atores afetados, com a integração dos seguintes componentes:

- O quadro de referência estratégico;

- As questões fundamentais, identificadas na proposta do plano com potenciais implicações ambientais; e

- Os fatores ambientais, pertinentes para a avaliação, classificadas pelas seguintes etapas:

1. Análise da situação existente e das principais tendências;

2. Efeitos esperados e avaliação de oportunidades e riscos;

3. Proposta de diretrizes de seguimento: planejamento, monitoramento e gestão;

4. Quadro de governança para a ação.

$\mathrm{Na}$ análise da situação de referência e das principais tendências, associada a cada um dos FCD, recorreu-se a uma análise do tipo SWOT. O termo SWOT é uma sigla oriunda do idioma inglês, e um acrônimo de Forças (Strengths), Fraquezas (Weaknesses), Oportunidades (Opportunities) e Ameaças (Threats). Com isso foi realizado um diagnóstico geral das características ambientais, patrimoniais e de ordenamento do território existentes na cidade, identificando um conjunto de elementos positivos e negativos que ocasionavam as ameaças e oportunidades. 
Os FCDs constituíram os temas mais importantes a serem abordados no âmbito da AAE e identificaram os aspectos que deveriam ser considerados durante a tomada de decisão. O objetivo da definição dos FCDs era assegurar o foco da AAE, estabelecendo o alcance da avaliação de forma a perceber o enquadramento em que esta se realizava. A definição dos FCDs resultou, numa primeira fase, da interação entre os objetivos do Quadro de Referência Estratégico - QRE preconizado e os Objetivos Estratégicos - QE inerentes à proposta de revisão do PDM de Monção, que se relacionem com os Fatores Ambientais - FA, ilustrados na Figura 5:

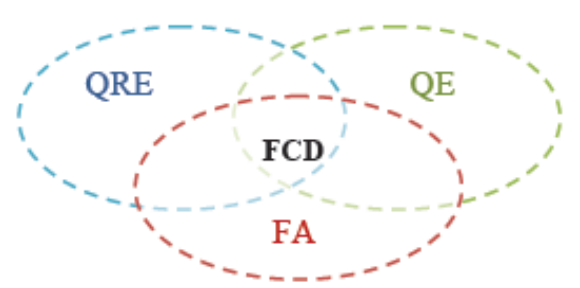

Figura 5 - Representação esquemática da determinação dos FCDs (adaptado de PARTIDÁRIO, apud CMM, 2008).

Da análise de cada um dos FCDs resultou a identificação de diferentes domínios, objetivos de sustentabilidade e indicadores que contribuíram para avaliar a viabilidade e sustentabilidade da estratégia preconizada nas grandes opções da revisão do PDM de Monção, pretendendo facilitar a avaliação e contribuir para uma tomada de decisão consciente e adequada. Neste contexto, os FCD identificados foram:

- Biodiversidade

- Patrimônio Cultural

- Fatores Físicos

- Ordenamento do Território, Desenvolvimento Regional e Competitividade

O relatório salientou o fato de as opções estratégicas que formalizaram o PDM terem sido acompanhadas pelas entidades com responsabilidades ambientais específicas, e, portanto, já impregnadas de iniciativas de sustentabilidade que as configuravam como opções estratégicas ambientais. Assim, não foram identificados impactos ambientais estratégicos significativos não mitigáveis ou não compensáveis decorrentes diretamente das opções estratégicas do PDM. 
A importância do acompanhamento da implementação do PDM de Monção foi estabelecida por meio da atualização periódica do plano de controle proposto, a fim de monitorar a evolução dos principais indicadores de sustentabilidade face às metas estipuladas em documentos estratégicos, que poderiam ter influência direta nas questões relacionadas com o ordenamento do uso e ocupação do solo e na qualidade ambiental da cidade. O quadro de governança para a ação foi considerado fundamental para o sucesso da implementação do PDM de Monção, uma vez que identificou as responsabilidades institucionais dos vários intervenientes na AAE, em todo o processo de implementação do próprio PDM.

Como resultado, as linhas orientadoras apresentadas na AAE identificaram e preconizaram a possibilidade de desenvolvimento e de aumento de competitividade para Monção, potencializado pela valorização do patrimônio natural e construído e pela afirmação de sua identidade cultural. A proposta de revisão do PDM de Monção apresentou como uma das grandes opções estratégicas o "Aumento da Competitividade Econômica e Investimento Empresarial do Conselho", onde foi prevista a instalação de várias zonas industriais na cidade (mais especificamente a implementação das chamadas Zona Industrial de BarbeitaMessegães, a Zona Industrial de Lara/Troporiz, e a implementação do Parque Empresarial da Lagoa).

A revisão do PDM de Monção procurou incluir as propostas de construção destes distritos industriais com a consideração de outros planos ambientais nacionais existentes, aproveitando para criar subsídios para a elaboração de um plano relativo ao patrimônio cultural e propostas de aproveitamento da infraestrutura existente para o direcionamento dos atuais vetores de expansão.

Na sequência será apresentado um mapa de Portugal com a sinalização do município de Monção, conforme ilustra a Figura 6, um resumo das temáticas abordadas, os objetivos propostos e impactos relacionados, além dos indicadores selecionados para cada avaliação e as tabelas de análises referentes às forças, fraquezas, oportunidades e riscos identificados para a estratégia adotada. 


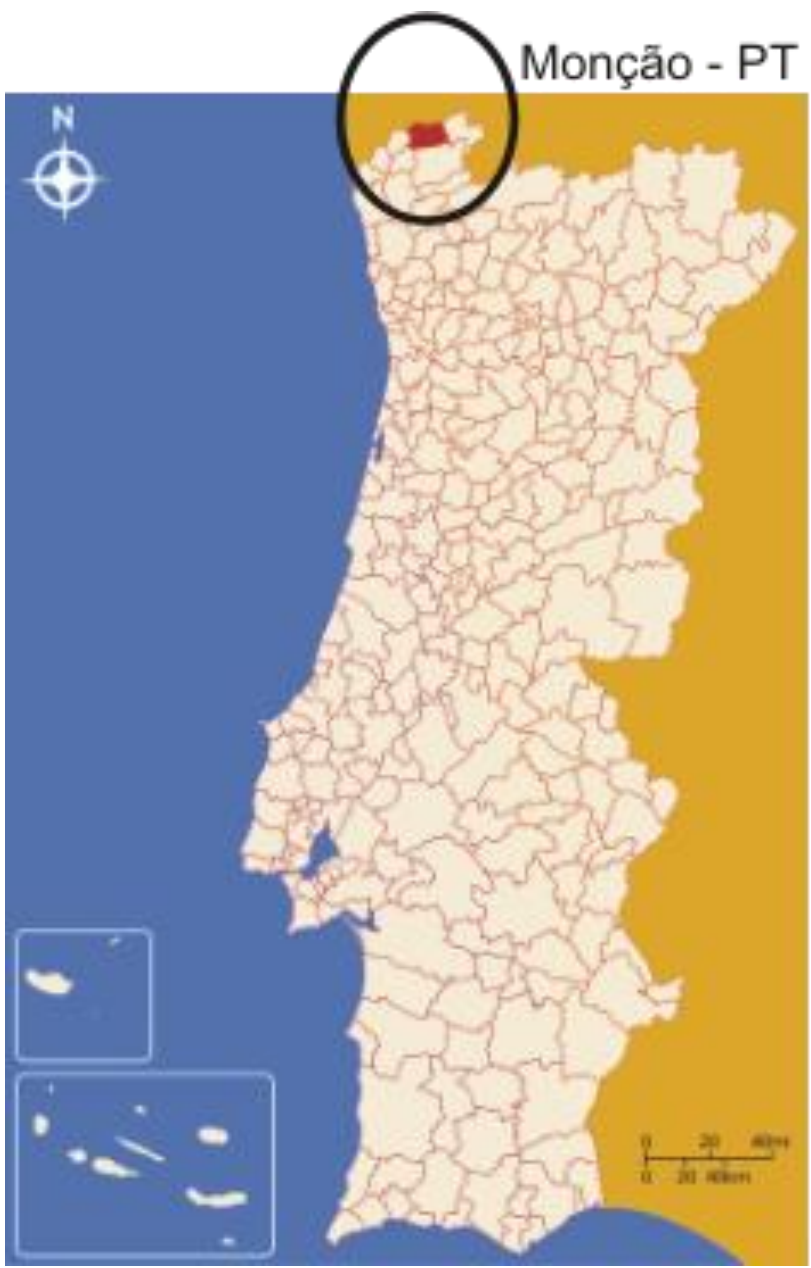

Figura 6 - Município de Monção (em vermelho) em Portugal

(fonte: http://terrasdeportugal.wdfiles.com/local--files/ilustrar:mapas/moncao.png) 


\section{BIODIVERSIDADE}

Quanto à biodiversidade, o caso de Monção contempla os seguintes objetivos e indicadores, em função do domínio:

\begin{tabular}{|c|c|c|}
\hline DOMÍNIO & OBJETIVOS & INDICADORES \\
\hline Áreas classificadas & $\begin{array}{l}\text { 1. Promover a valorização e a } \\
\text { conservação do patrimônio } \\
\text { natural, cultural em áreas } \\
\text { classificadas; } \\
\text { 2. Proteger e valorizar a } \\
\text { paisagem principalmente } \\
\text { nas áreas classificadas; } \\
\text { 3. Evitar prejuízos em áreas } \\
\text { classificadas, sítios } \\
\text { geológicos e sobre espécies } \\
\text { protegidas. }\end{array}$ & $\begin{array}{l}\text { - Áreas protegidas e } \\
\text { Reservas Naturais; } \\
\text { - Superfície do } \\
\text { Município com estatuto } \\
\text { de Área protegida; } \\
\text { - Planos de gestão para } \\
\text { áreas classificadas; } \\
\text { - Trilhas de interpretação } \\
\text { devidamente equipadas } \\
\text { e sinalizadas. }\end{array}$ \\
\hline $\begin{array}{l}\text { Diversidade de } \\
\text { espécies }\end{array}$ & $\begin{array}{l}\text { 1. Manter a biodiversidade } \\
\text { evitando perdas } \\
\text { irreversíveis; } \\
\text { 2. Reabilitação de habitats e de } \\
\text { espécies para níveis viáveis. }\end{array}$ & $\begin{array}{l}\text { - Espécies ameaçadas e } \\
\text { protegidas; } \\
\text { - Habitats prioritários. }\end{array}$ \\
\hline $\begin{array}{l}\text { Conservação da } \\
\text { natureza, } \\
\text { biodiversidade e } \\
\text { paisagem }\end{array}$ & $\begin{array}{l}\text { 1. Proteger a diversidade } \\
\text { biológica e da paisagem; } \\
\text { 2. Assegurar a gestão } \\
\text { sustentável de locais-chave } \\
\text { para a conservação de } \\
\text { determinadas espécies, bem } \\
\text { como dos processos } \\
\text { ecológicos associados; } \\
\text { 3. Controlar a proliferação de } \\
\text { espécies exóticas invasoras } \\
\text { com risco ecológico } \\
\text { conhecido. }\end{array}$ & $\begin{array}{l}\text { - Planos de gestão e } \\
\text { ações de conservação } \\
\text { de espécies e habitats; } \\
\text { - Zonas de elevado valor } \\
\text { paisagístico; } \\
\text { - Áreas de distribuição de } \\
\text { espécies exóticas } \\
\text { invasoras com risco } \\
\text { conhecido; } \\
\text { - Ações de controle de } \\
\text { espécies exóticas com } \\
\text { risco ecológico } \\
\text { conhecido. }\end{array}$ \\
\hline $\begin{array}{l}\text { Gestão e valorização } \\
\text { da conservação da } \\
\text { floresta }\end{array}$ & $\begin{array}{l}\text { 1. Promover a gestão } \\
\text { sustentável e a conservação } \\
\text { da floresta; } \\
\text { 2. Fomentar oportunidades de } \\
\text { fruição sustentável em áreas } \\
\text { naturais florestadas. }\end{array}$ & $\begin{array}{l}\text { Zonas de intervenção } \\
\text { florestal; } \\
\text { - Parques e percursos } \\
\text { devidamente equipados } \\
\text { e sinalizados, em áreas } \\
\text { florestais. }\end{array}$ \\
\hline
\end{tabular}

Tabela 1 - Temas relativos à biodiversidade (adaptado de CMM, 2008) 
A partir da análise da interação entre os diferentes domínios, foram estipulados as seguintes forças, fraquezas, oportunidades e riscos:

\begin{tabular}{|c|c|}
\hline FORÇAS & FRAQUEZAS \\
\hline $\begin{array}{l}\text { - Município com elevado valor ecológico e } \\
\text { conservacionista, sobretudo associado ao } \\
\text { Vale do Rio Minho e à ocorrência de } \\
\text { lobo; } \\
\text { - Presença de um sítio de importância } \\
\text { comunitária - Rio Minho. }\end{array}$ & $\begin{array}{l}\text { - Incapacidade da gestão adequada dos } \\
\text { valores ecológicos presentes; } \\
\text { - Pressão urbanística sobre as localizações } \\
\text { dos valores ecológicos presentes. }\end{array}$ \\
\hline OPORTUNIDADES & $A M E A C B A$ \\
\hline $\begin{array}{l}\text { - Sensibilizar os agentes da área de } \\
\text { planejamento para a compatibilização dos } \\
\text { interesses ecológicos e socioeconômicos; } \\
\text { - Melhorar e promover uma gestão } \\
\text { adequada dos valores ecológicos } \\
\text { classificados no âmbito do Vale do Rio } \\
\text { Minho; } \\
\text { - Definir planos e linhas de ação com vista } \\
\text { à conservação dos principais valores } \\
\text { ecológicos inseridos na área do Rio } \\
\text { Minho correspondente ao município de } \\
\text { Monção. }\end{array}$ & $\begin{array}{l}\text { Possível conflito de interesse no Vale do } \\
\text { Rio Minho; } \\
\text { - Possível falta de recursos humanos e } \\
\text { financeiros com vista à correta gestão da } \\
\text { biodiversidade existente na área } \\
\text { classificada do Município. }\end{array}$ \\
\hline
\end{tabular}

Tabela 2 - SWOT relativo à biodiversidade (adaptado de CMM, 2008)

\section{PATRIMÔNIO CULTURAL}

Quanto ao patrimônio cultural, o caso de Monção contempla os seguintes objetivos e indicadores, em função do domínio: 


\begin{tabular}{|l|l|l|}
\hline \multicolumn{1}{|c|}{ DOMÍNIO } & \multicolumn{1}{|c|}{ OBJETIVOS } & \multicolumn{1}{c|}{ INDICADORES } \\
\hline $\begin{array}{l}\text { Identidade histórica e } \\
\text { cultural }\end{array}$ & $\begin{array}{l}\text { 1. Preservar edifícios } \\
\text { históricos, locais } \\
\text { arqueológicos e outras } \\
\text { características culturais } \\
\text { importantes; } \\
\text { 2. Promover a reabilitação e } \\
\text { dinamização de edifícios } \\
\text { históricos; } \\
\text { 3. Fomentar a reabilitação e a } \\
\text { ocupação de edifícios nas } \\
\text { proximidades de centros } \\
\text { históricos; } \\
\text { 4. Valorizar a diversidade e a } \\
\text { identidade local; } \\
\text { 5. Promover o turismo } \\
\text { cultural. }\end{array}$ & $\begin{array}{l}\text { Obras em edifícios históricos } \\
\text { (recuperação/manutenção); } \\
\text { Reabilitação de edifícios urbanos } \\
\text { degradados; } \\
\text { Edifícios degradados ocupados e fora } \\
\text { de uso; } \\
\text { Residentes que registrem melhorias } \\
\text { em atividades ao ar livre; } \\
\text { População que reside nas } \\
\text { proximidades dos espaços verdes } \\
\text { (parques); } \\
\text { Residentes que registrem aumento nas } \\
\text { iniciativas culturais; } \\
\text { Participantes, não residentes, em } \\
\text { iniciativas e atividades culturais. }\end{array}$ \\
\hline
\end{tabular}

Tabela 3 - Temas relativos ao Patrimônio Cultural (adaptado de CMM, 2008)

A partir da análise da interação entre os diferentes domínios, foram estipulados as seguintes forças, fraquezas, oportunidades e riscos:

\begin{tabular}{|c|c|}
\hline FORÇAS & FRAQUEZAS \\
\hline $\begin{array}{l}\text { - A vila histórica de Monção, situada no } \\
\text { interior das muralhas, constitui um } \\
\text { espaço urbano de elevado potencial } \\
\text { cultural, histórico, paisagístico e } \\
\text { morfológico; } \\
\text { - O valor cultural de Monção fez dele } \\
\text { patrimônio cultural internacional; } \\
\text { - Riqueza e diversidade do território em } \\
\text { patrimônio edificado, histórico e } \\
\text { cultural; } \\
\text { - A cidade de Monção tem uma grande } \\
\text { variedade de atividades turísticas, } \\
\text { desportivas e culturais. }\end{array}$ & $\begin{array}{l}\text { - Vila histórica de Monção sujeita a } \\
\text { elevada pressão; } \\
\text { - Saturação da vila de Monção devido } \\
\text { às pressões de tráfego e } \\
\text { estacionamento, que reduzem a } \\
\text { qualidade que seu espaço } \\
\text { eminentemente cultural poderia } \\
\text { invocar; } \\
\text { - Falta de estacionamento no centro } \\
\text { histórico; } \\
\text { - Mau estado de conservação do } \\
\text { patrimônio arquitetônico e áreas } \\
\text { envolventes. }\end{array}$ \\
\hline OPORTUNIDADES & $A M E A C ̧ A S$ \\
\hline $\begin{array}{l}\text { - Elaboração do Plano de Preservação } \\
\text { do Centro Histórico de Monção, que } \\
\text { contribuirá para a requalificação do } \\
\text { centro histórico; } \\
\text { - Preservação do patrimônio } \\
\text { arquitetônico de Monção como } \\
\text { desenvolvimento do setor turístico do } \\
\text { conselho. }\end{array}$ & $\begin{array}{l}\text { Possíveis intervenções construtivas } \\
\text { ocasionadoras de rupturas com o } \\
\text { edificado existente na vila histórica de } \\
\text { Monção. }\end{array}$ \\
\hline
\end{tabular}

Tabela 4 - SWOT relativo ao Patrimônio Cultural (adaptado de CMM, 2008) 


\section{FATORES FÍSICOS}

Quanto aos fatores físicos, o caso de Monção contempla os seguintes objetivos e indicadores, em função do domínio:

\begin{tabular}{|c|c|c|}
\hline DOMÍNIO & OBJETIVO & INDICADORES \\
\hline Proteção do solo & $\begin{array}{l}\text { 1. Aumentar a proteção do solo; } \\
\text { 2. Diminuir a contaminação do } \\
\text { solo; } \\
\text { 3. Minimizar o impacto } \\
\text { provocado por resíduos; } \\
\text { 4. Promover a reabilitação e uso } \\
\text { de áreas degradadas. }\end{array}$ & $\begin{array}{l}\text { - Densidade habitacional; } \\
\text { - Queixas de depósito } \\
\text { indevido de resíduos no } \\
\text { solo; } \\
\text { - Produção de resíduos; } \\
\text { - Valorização de resíduos; } \\
\text { - Recuperação de áreas } \\
\text { degradadas; } \\
\text { - Áreas com risco de } \\
\text { inundação. }\end{array}$ \\
\hline $\begin{array}{l}\text { Água superficial } \\
\text { e subterrânea }\end{array}$ & $\begin{array}{l}\text { 1. Reduzir os níveis de poluição } \\
\text { da água para níveis que não } \\
\text { prejudiquem os sistemas } \\
\text { naturais; } \\
\text { 2. Aumentar o aproveitamento e } \\
\text { reutilização de água; } \\
\text { 3. Manter e recuperar processos } \\
\text { ecológicos chave; } \\
\text { 4. Uso eficiente da água. }\end{array}$ & $\begin{array}{l}\text { - Qualidade da água } \\
\text { superficial e subterrânea; } \\
\text { - Utilização da água por } \\
\text { setor e proporção } \\
\text { reutilizada; } \\
\text { - População servida por } \\
\text { sistema de drenagem de } \\
\text { águas superficiais. }\end{array}$ \\
\hline $\begin{array}{l}\text { Água para } \\
\text { consumo } \\
\text { humano }\end{array}$ & $\begin{array}{l}\text { 1. Assegurar a qualidade e } \\
\text { quantidade da água para } \\
\text { consumo humano; } \\
\text { 2. Uso eficiente da água. }\end{array}$ & $\begin{array}{l}\text { - População servida por rede } \\
\text { de abastecimento de água } \\
\text { para consumo; } \\
\text { - Plano analítico/Análises } \\
\text { não realizadas; } \\
\text { - Violações aos valores } \\
\text { paramétricos; } \\
\text { - Consumo de água. } \\
\end{array}$ \\
\hline Qualidade do ar & $\begin{array}{l}\text { 1. Reduzir a poluição do ar; } \\
\text { 2. Diminuir as emissões de } \\
\text { gases de efeito estufa; } \\
\text { 3. Reduzir a vulnerabilidade e } \\
\text { os efeitos de alterações } \\
\text { climáticas (inundacõos, } \\
\text { incêndios, constrangimentos } \\
\text { no tráfego devido a } \\
\text { condições climáticas } \\
\text { extremas, etc); } \\
\text { 4. Diminuir a necessidade de } \\
\text { viajar; }\end{array}$ & 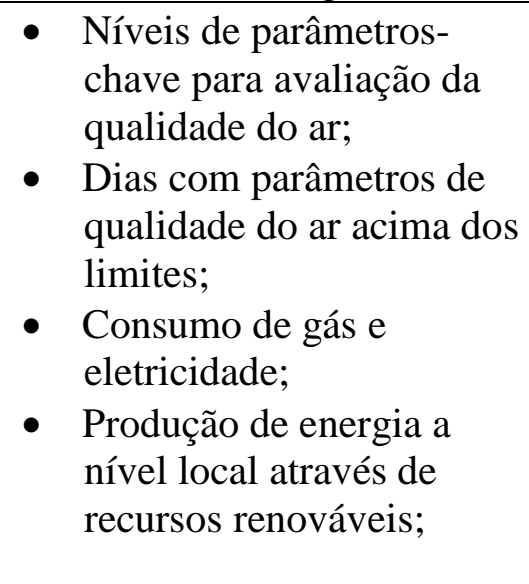 \\
\hline
\end{tabular}




\begin{tabular}{|l|l|l|}
\hline 5. $\begin{array}{l}\text { Aumentar a oferta de modos } \\
\text { de transporte sustentáveis; } \\
\text { 6. } \begin{array}{l}\text { Reduzir as doenças } \\
\text { respiratórias. }\end{array}\end{array}$ & $\begin{array}{l}\text { Consumos energéticos } \\
\text { médios por edifício e por } \\
\text { habitante; }\end{array}$ \\
& $\begin{array}{l}\text { - Emissões de CO2; } \\
\end{array}$ & $\begin{array}{l}\text { Risco de ocorrência de } \\
\text { cheias e de incêndios; }\end{array}$ \\
& $\begin{array}{l}\text { Distância e acesso a } \\
\text { serviços gerais; }\end{array}$ \\
& $\begin{array}{l}\text { - Volumes de tráfego; } \\
\end{array}$ \\
& $\begin{array}{l}\text { Número de pessoas com } \\
\text { doenças respiratórias. }\end{array}$ \\
\hline
\end{tabular}

Tabela 5 - Temas relativos aos Fatores Físicos (adaptado de CMM, 2008)

A partir da análise da interação entre os diferentes domínios, foram estipulados as seguintes forças, fraquezas, oportunidades e riscos:

\begin{tabular}{|c|c|}
\hline FORÇAS & FRAQUEZAS \\
\hline $\begin{array}{l}\text { - A pouca expressão da indústria } \\
\text { transformadora não origina graves } \\
\text { problemas de poluição na cidade; } \\
\text { - Zonas de recreio e lazer construídas ao } \\
\text { longo dos cursos de água; } \\
\text { - Condições naturais para a produção de } \\
\text { energia eólica; } \\
\text { - Alguns trechos dos corpos hídricos } \\
\text { existentes mantêm as suas margens } \\
\text { inalteradas. }\end{array}$ & $\begin{array}{l}\text { - Má qualidade da água de alguns } \\
\text { corpos d'água; } \\
\text { - Má qualidade da água de } \\
\text { abastecimento por captações } \\
\text { existentes nos leitos dos corpos } \\
\text { hídricos principais e afluentes; } \\
\text { - Descarga de resíduos provenientes de } \\
\text { algumas pedreiras em alguns corpos } \\
\text { d'água; } \\
\text { - Descarga pontual nos corpos hídricos } \\
\text { de efluentes domésticos provenientes } \\
\text { de fossas sépticas e de efluentes } \\
\text { provenientes de área de pecuária; } \\
\text { - Abandono nas margens de corpos } \\
\text { hídricos de embalagens de produtos } \\
\text { químicos e equipamentos fora de uso; } \\
\text { - Aplicação incorreta de chorumes para } \\
\text { fertilização e uso excessivo de } \\
\text { produtos químicos nas áreas agrícolas } \\
\text { que margeiam os corpos hídricos } \\
\text { existentes; } \\
\text { - Baixa taxa de resíduos valorizados; } \\
\text { Má localização de alguns ecopontos. }\end{array}$ \\
\hline OPORTUNIDADES & $A M E A C S A S$ \\
\hline $\begin{array}{l}\text { - Infraestrutura inerente aos sistemas de } \\
\text { aproveitamento das águas em alguns } \\
\text { corpos hídricos: moinhos, açudes, } \\
\text { poças e sistemas de irrigação; }\end{array}$ & $\begin{array}{l}\text { - Possíveis depósitos ilegais de resíduos } \\
\text { de construção civil e de demolição; } \\
\text { - Risco de incêndio; }\end{array}$ \\
\hline
\end{tabular}


- Elevadas potencialidades dos cursos de água para a prática de pesca desportiva;

- Elevado valor paisagístico e condições naturais excepcionais para fins lúdicos e recreativos, em alguns cursos de água;

- Produção vinícola poderá constituir um vetor estratégico de desenvolvimento da cidade.

Tabela 6 - SWOT relativo aos Fatores Físicos (adaptado de CMM, 2008)

\section{ORDENAMENTO DO TERRITÓRIO, DESENVOLVIMENTO REGIONAL E COMPETITIVIDADE}

Quanto ao ordenamento do território, desenvolvimento regional e competitividade, o caso de Monção contempla os seguintes objetivos e indicadores, em função do domínio:

\begin{tabular}{|c|c|c|}
\hline DOMÍNIO & OBJETIVOS & INDICADORES \\
\hline Saúde Humana & $\begin{array}{l}\text { 1. Promover condições que } \\
\text { contribuam para a } \\
\text { melhoria da saúde; } \\
\text { 2. Promover modos de vida } \\
\text { mais saudáveis; } \\
\text { 3. Proteger e promover a } \\
\text { saúde humana; } \\
\text { 4. Diminuir os níveis de } \\
\text { ruído e vibração; } \\
\text { 5. Aumentar as } \\
\text { oportunidades de } \\
\text { atividades e exercício ao } \\
\text { ar livre. }\end{array}$ & $\begin{array}{l}\text { - Tamanho da população; } \\
\text { - } \quad \text { Variações demográficas; } \\
\text { - Longevidade/Mortalidade } \\
\text { infantil; } \\
\text { - Acidentes rodoviários; } \\
\text { - População afetada por níveis } \\
\text { - } \quad \text { de ruído ambiental; } \\
\text { - Opinião geral dos residentes. }\end{array}$ \\
\hline $\begin{array}{l}\text { Ambiente Urbano } \\
\text { e Ordenamento do } \\
\text { Território }\end{array}$ & $\begin{array}{l}\text { 1. Consolidação do espaço } \\
\text { urbano; } \\
\text { 2. Requalificação e } \\
\text { valorização de edifícios } \\
\text { públicos; } \\
\text { 3. Reabilitação e ocupação } \\
\text { de edifícios degradados; } \\
\text { 4. Promover um correto } \\
\text { ordenamento biofísico e } \\
\text { paisagístico; } \\
\text { 5. Melhorar a quantidade e } \\
\text { qualidade de espaços } \\
\text { públicos ao ar livre; }\end{array}$ & $\begin{array}{l}\text { - População residente no } \\
\text { Município; } \\
\text { - População residente em } \\
\text { núcleos urbanos; } \\
\text { - Zona urbanizada ocupada; } \\
\text { - Zona urbanizável no PDM } \\
\text { em vigor; } \\
\text { - Licenças para construção } \\
\text { - } \quad \text { Adifícios); } \\
\text { - naturais no município; } \\
\text { - Área de reserva natural } \\
\text { excluída por efeito do POT; }\end{array}$ \\
\hline
\end{tabular}




\begin{tabular}{|c|c|c|}
\hline & $\begin{array}{l}\text { 6. Reduzir a necessidade de } \\
\text { excluir áreas de reservas } \\
\text { naturais. }\end{array}$ & $\begin{array}{l}\text { - Áreas de reserva natural por } \\
\text { intervenções de interesse } \\
\text { social. }\end{array}$ \\
\hline $\begin{array}{l}\text { Desenvolvimento } \\
\text { regional e } \\
\text { competitividade }\end{array}$ & $\begin{array}{l}\text { 1. Melhorar a } \\
\text { acessibilidade; } \\
\text { 2. Reduzir as emissões de } \\
\text { gases de efeito estufa; } \\
\text { 3. Fomentar o } \\
\text { desenvolvimento regional } \\
\text { sustentável; } \\
\text { 4. Promover o turismo } \\
\text { sustentável; } \\
\text { 5. Aumentar a } \\
\text { competitividade } \\
\text { econômica. }\end{array}$ & $\begin{array}{l}\text { - Rede viária; } \\
\text { - Volumes de tráfego; } \\
\text { - Mobilidade sustentável; } \\
\text { - Unidades de turismo } \\
\text { - } \text { Imstentável; } \\
\text { - } \\
\text { áreas adequacadas. }\end{array}$ \\
\hline
\end{tabular}

Tabela 7 - Temas relativos ao Ordenamento Territorial (adaptado de CMM, 2008)

A partir da análise da interação entre os diferentes domínios, foram estipulados as seguintes forças, fraquezas, oportunidades e riscos:

\begin{tabular}{|c|c|}
\hline FORÇAS & FRAQUEZAS \\
\hline $\begin{array}{l}\text { - Localização geográfica; } \\
\text { - Forte diversidade ecológica e paisagística; } \\
\text { - } \quad \text { Posicionamento do Vale do Minho no } \\
\text { contexto transfronteiriço; } \\
\text { - } \quad \text { Local de passagem dos caminhos de São } \\
\text { Tiago de Compostela; } \\
\text { - Identidade reforçada pela Associação Vale } \\
\text { do Minho; } \\
\text { - Sinais evidentes do alargamento } \\
\text { institucional nacional e da cooperação } \\
\text { transfronteiriça; } \\
\text { - Associativismo (Associação de } \\
\text { Municípios do Vale do Minho, Associação } \\
\text { de Desenvolvimento Rural Integrado de } \\
\text { Atividades Culturais no Vale do Minho); } \\
\text { - Localização estratégica de áreas para } \\
\text { atividades. }\end{array}$ & 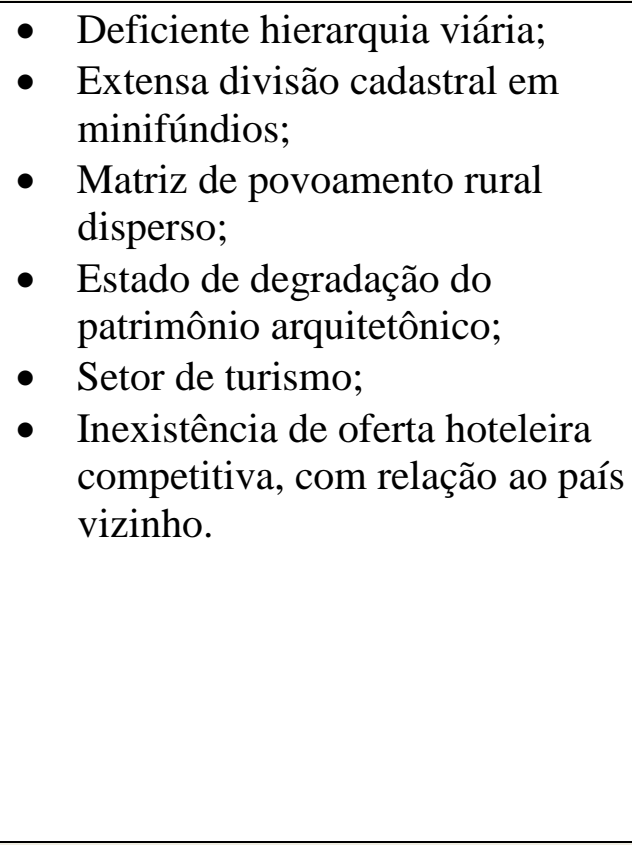 \\
\hline OPORTUNIDADES & AMEACAS \\
\hline $\begin{array}{l}\text { - } \text { Construção da ecopista Valença-Monção; } \\
\text { - Recuperação do centro histórico; } \\
\text { - Requalificação das Caldas de Monção; } \\
\text { - Renovação e recuperação do patrimônio } \\
\text { edificado existente; }\end{array}$ & $\begin{array}{ll}\text { - } & \text { Desertificação do interior; } \\
\text { - } & \text { Envelhecimento da população } \\
\text { - } & \text { Ausência de projetos que } \\
& \text { diversifiquem o espaço } \\
& \text { econômico, consolidando e } \\
& \text { complementando a atividade }\end{array}$ \\
\hline
\end{tabular}


- Dinamização do turismo rural em edifícios recuperados;

- Implantação de atividades econômicas com significativa importância a nível internacional que poderão funcionar como âncoras de desenvolvimento do território do Vale do Minho;

- Parque eólico do Vale do Minho;

- Projeto de qualificação do Aeródromo do Vale do Minho;

- Valorização do potencial endógeno do território do Vale do Minho;

- Programa de Qualificação das competências da administração local no Vale do Minho;

- Programa de Qualificação dos recursos turísticos no Vale do Minho;

- Projeto de Promoção e Gestão da Imagem do Vale do Minho direcionado para a promoção territorial Vale do Minho;

- Promoção e dinamização de uma política cultural intermunicipal - Rede Cultural Intermunicipal e Biblioteca Virtual do Vale do Minho. agrícola, como o turismo rural ou o artesanato;

- Proximidades da oferta turística de outras regiões, como a Galícia;

- Competição com outras associações de municípios vizinhos;

- Inexistência de trabalhadores locais qualificados que assegurem apostas vencedoras nas atividades mais significativas para a região;

- Desconhecimento por parte de muitos agentes do setor de turismo das características da região;

- Falta de estrutura do setor de turismo ao nível local;

- Fraca visibilidade dos produtos existentes de uma forma regionalmente diferenciada;

- Degradação da paisagem (incêndios, pedreiras);

- Bloqueios institucionais que dificultam a cooperação;

- Dependência de financiamento externo público e/ou privado;

- Defasagem entre planos e projetos.

Tabela 8 - SWOT relativo ao Ordenamento Territorial (adaptado de CMM, 2008)

O relatório da AAE realizado para o direcionamento do plano diretor de uso e ocupação do solo de Monção em Portugal é apresentado por meio de uma matriz estratégica. A técnica SWOT permite avaliar pontos fortes (ou S, do termo em inglês Strengths), pontos fracos (ou W, de Weaknesses), oportunidades (ou O, de Opportunities) e ameaças (ou T, de Threats). Ela caracteriza um modelo de organização das informações que permite ao tomador de decisão optar pelos direcionamentos de suas ações pautadas pela interação de diferentes critérios, sem a prévia determinação das metas. Em função da complexidade destas interações, este modelo é mais direcionado para os atores interessados que já estejam envolvidos e familiarizados com os temas abordados, sendo mais utilizados para o acompanhamento da situação atual.

O uso de indicadores facilita o entendimento dos parâmetros utilizados para medir o avanço das alterações no território. Assim, o estabelecimento de metas pode ser balizado por critérios compreensíveis por diferentes atores. Desta maneira é possível implementar um 
processo de monitoramento que seja compreensível pelos setores envolvidos de uma maneira geral.

Pela análise realizada, se pode identificar que alguns indicadores estão presentes em mais de um objetivo, sendo que tais objetivos pertencem a FCD distintos. Por exemplo, as questões referentes à biodiversidade envolvem a conservação dos recursos naturais, incluindo o controle das espécies invasoras, a localização de áreas de conservação e o uso destes recursos como pertencentes às atividades turísticas, atribuindo assim, não apenas sentido de preservação, mas também valor econômico para os recursos, e ainda considerações sobre saúde pública dos moradores da região. Os fatores físicos também se relacionam com a preservação de processos ecológicos chaves. O uso múltiplo do mesmo indicador sugere as potencialidades da avaliação integrada das diferentes funções que podem representar para os FCDs.

A interação dos FCDs por meio dos indicadores selecionados ilustra como as avaliações de impactos cumulativos e sinérgicos de diferentes aspectos podem sugerir alternativas distintas. Este tipo de estratégia poderia ser aplicado nas ações de planejamento do município de São Carlos, caracterizadas por análises feitas por setores fragmentados, identificados em função das características atuais do Plano Diretor do Município, apresentado em capítulo específico do presente trabalho.

\subsection{2 - AAE PARA O PLANO DE USO E OCUPAÇÃO DO SOLO DE MID DEVON - INGLATERRA (MDDC, 2006)}

Segundo o censo realizado em 2003, Mid Devon é o terceiro maior distrito da região de Devon, no Sudoeste na Inglaterra, ilustrado na Figura 7, e possui uma população de 70.000 habitantes, com densidade menor que um habitante por hectare. É considerado uma das ocupações mais esparsas da Inglaterra e País de Gales, classificado em $30^{\circ}$ lugar dos 376 colocados, segundo dados de 2001. A maior parte da população está na parte Leste, em Tiverton com 18.300 habitantes, e Collumpton com 7.800 habitantes, distantes a $6 \mathrm{~km}$ cada uma. Crediton é o maior povoado, com 6700 habitantes, localizado ao Oeste do distrito. A localização destas 3 cidades está ilustrado na Figura 8. A maior parte da população vive fora destes três municípios, em vilas que não excedem 3.000 habitantes. 


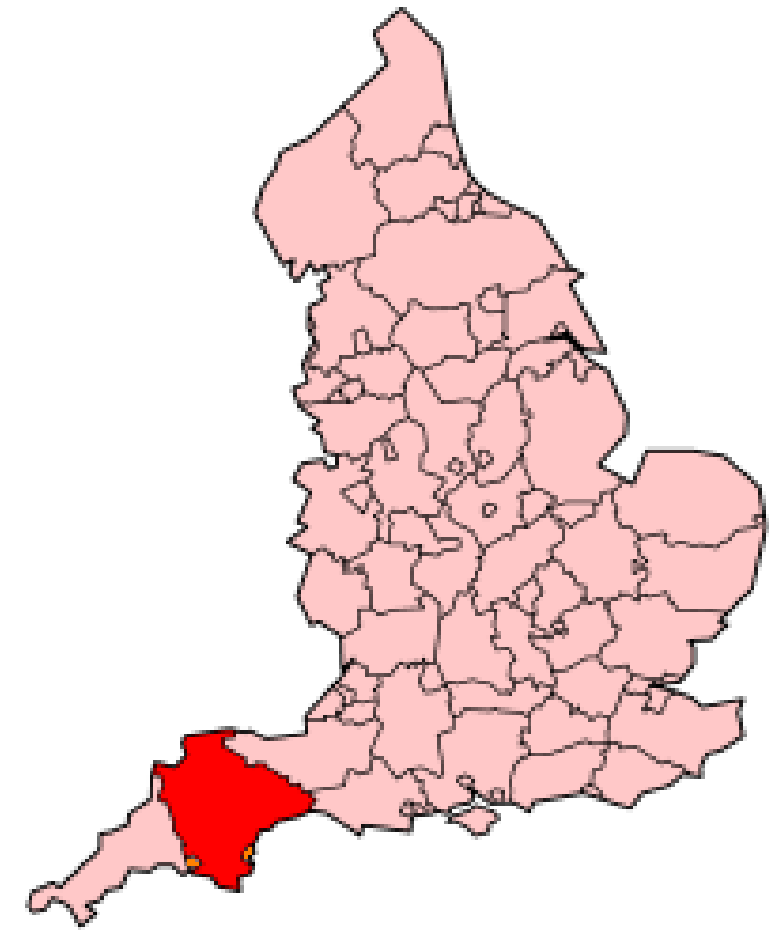

Figura 7 - Região de Devon (em vermelho) na Inglaterra

(fonte: http://upload.wikimedia.org/wikipedia/commons/9/9a/EnglandDevon.png)

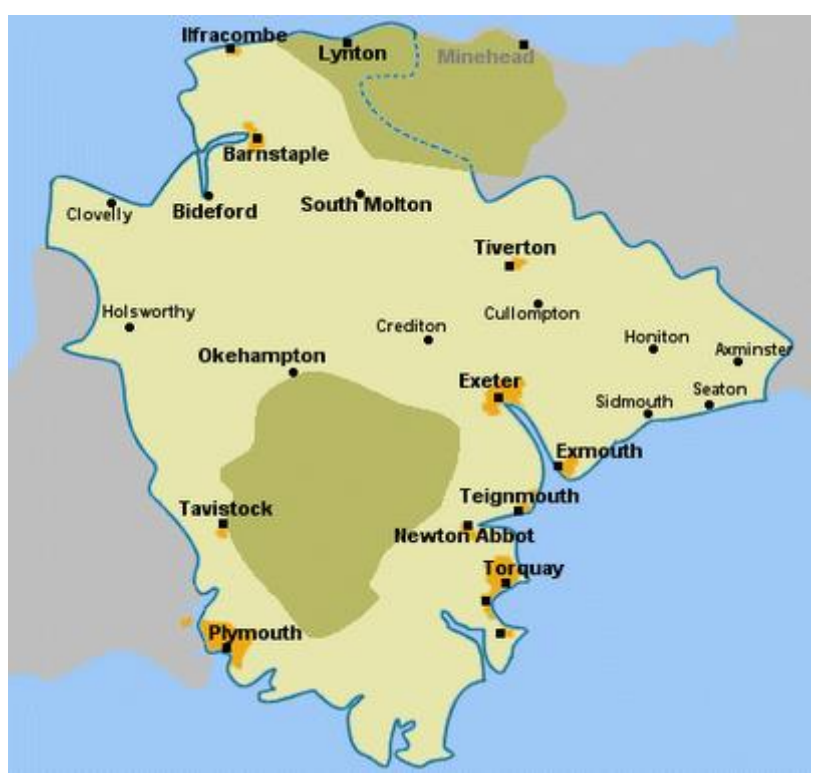

Figura 8 - Municípios da região de Devon

(fonte:http://2.bp.blogspot.com/_Mq4S1uVPJOo/SN7Dei0z7QI/AAAAAAAACyU/RqB7C4 MqHfk/s400/devonmap.gif) 
A paisagem de Mid Devon é marcada por montanhas de pastagens e florestas, cortadas por escarpas lindeiras e fundos de vale, com uma série de mirantes com vistas panorâmicas. Possui grandes áreas abandonadas de solo fértil. Há pequenas vilas históricas compostas por cabanas e antigas igrejas. Sua montanhosa paisagem agrícola é definida por suas características físicas e ambientais. Mid Devon é calmo e possui clima úmido, sendo que a temperatura e pluviosidade anual são comparadas ao resto da Inglaterra, onde se chove menos do que nas áreas litorâneas. Sua geralmente ótima ou excelente qualidade das águas serve como importantes habitats de fauna. No entanto essa abundância de água com cheias periódicas tem implicações para a população e economia locais. A maior parte de Tiverton localiza-se na várzea dos rios Exe e Lowman e possui muitos sistemas artificiais de defesa de inundações.

A riqueza ambiental é garantida pelo patrimônio histórico e natural, com 2.560 construções listadas, 50 áreas de conservação e 49 monumentos catalogados. O preço da habitação está acima da média inglesa. No entanto, assim como na maior parte das áreas rurais, o subsídio para aluguel é limitado, sendo 14,1\% contra 19,2\% na média do país. Estudos demonstram uma considerável carência desta garantia.

Mid Devon possui uma forte economia local, com bom transporte rodoviário e ferroviário, sendo que sua principal linha férrea aproxima o centro regional Exeter até Taunton. Sua economia local possui um setor agrícola significativo, com extrações minerais e importante conhecimento do setor turístico, porém com pequenos serviços neste setor. As chaves da economia estão no empreendimento próprio, altos números de pequenos negócios e poucas taxas de desemprego. Mid Devon sofre com pequenos lucros comparados com os níveis nacionais e regionais, que contraposto com a alta média do custo das habitações é considerado como o principal problema da região.

Exeter possui a maior influência na economia de Mid Devon. Tiverton e Crediton possuem áreas atrativas próximas ao meio rural. Tiverton supre o consumo da clientela do setor Leste do distrito. Crediton cobre apenas demandas locais dos moradores rurais. Exeter é o grande centro de compras e empregos da maior parte dos moradores do distrito e Taunton possui um crescimento no comércio na parte Leste do distrito.

O presente estudo apresenta um resumo do relatório desenvolvido para a investigação de como o planejamento local de Mid Devon pode ser influenciado por outros planos e programas ou objetivos ambientais externos colocados pela gestão destas ações. $\mathrm{Na}$ Inglaterra, o estabelecimento do Planning and Compulsory Purchase Act 2004 incumbiu às autoridades locais a realização de uma avaliação ambiental de seus Planos de Uso e Ocupação 
do Solo Local. De acordo com a estratégia adotada pelo Reino Unido, para que seja atingido o desenvolvimento sustentável é necessário buscar ao mesmo tempo o progresso social com as demandas populacionais, uma efetiva proteção ao meio ambiente, o uso racional dos recursos naturais e a manutenção de altos e estáveis níveis de crescimento econômico e emprego.

Segundo a Diretiva Européia 2001/42/EC foram realizados a preparação de um relatório ambiental, consultas públicas, o encaminhamento dos resultados do relatório ambiental e da consulta para os tomadores de decisão, com a provisão da informação sobre a decisão e monitoramento. Estas ações foram realizadas em diferentes etapas:

A. Estabelecimento do contexto e bases de referência;

B. Delimitação do conteúdo da avaliação e desenvolvimento de alternativas;

C. Avaliação dos efeitos do plano;

D. Consulta pública sobre a interação entre o plano e o relatório ambiental;

E. Monitoramento dos impactos significativos da implementação do plano.

Para a realização da etapa A foram adotados os procedimentos ilustrados na Figura 6:

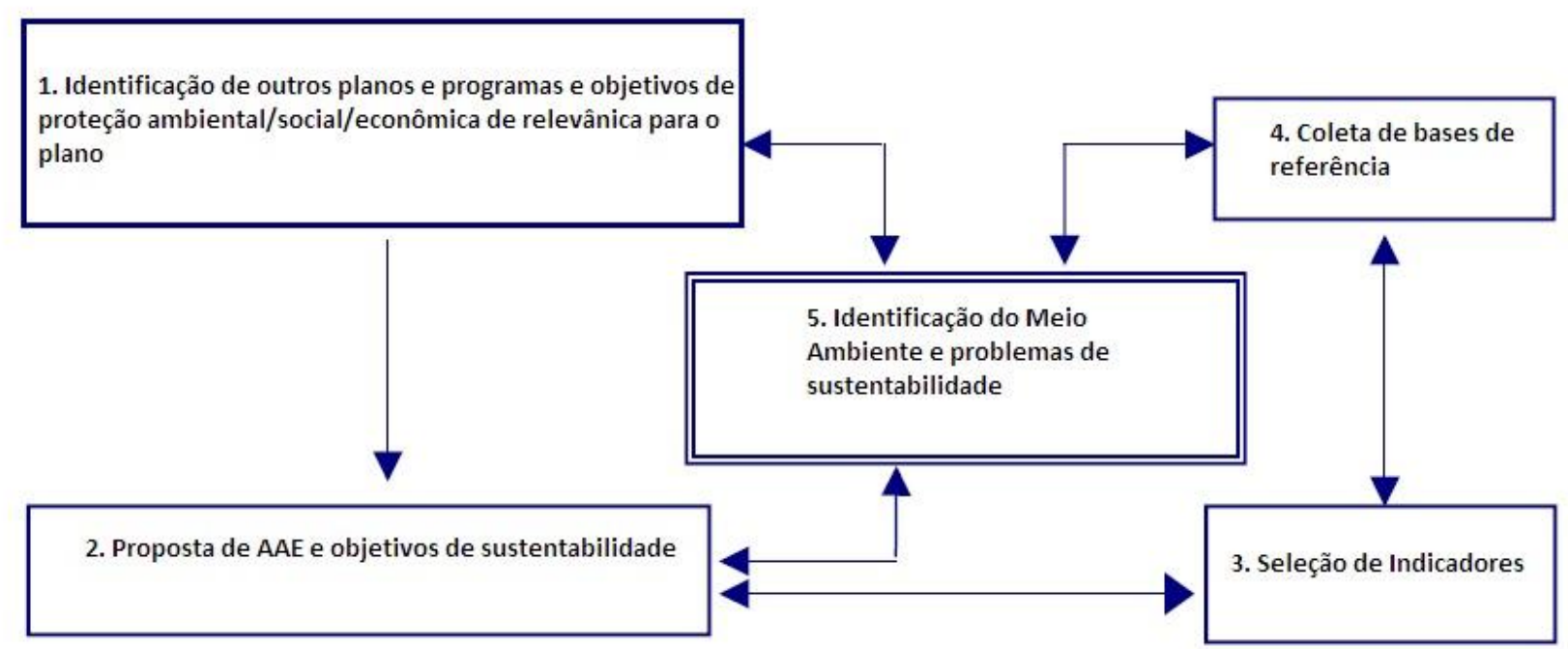

Figura 9 - Metodologia para seleção de contexto e bases de referência (adaptado de MDDC, 2006) 
A primeira alteração do plano local de Mid Devon ocorreu em 2002 com a consideração de outros documentos ambientais como:

- The UK Government's Strategy for Sustainable Development;

- Sustainability Appraisal of Regional Planning Guidance;

- Devon Country Council Structure Plan 2001-2016 Sustainability Appraisal; e

- A Sustainable Future or the South West.

O estudo considerou as características dos dados coletados e a origem dos interesses, confirmou as atualizações realizadas e identificou como estes dados poderiam ser aplicados como indicadores. As informações foram coletadas junto a órgãos especializados na área ambiental, como organizações da sociedade civil, agências ambientais federais e conselhos municipais. Os exames dos dados das bases de referência determinaram o potencial inicial dos indicadores apropriados e a relação com os objetivos de sustentabilidade. Definiram os objetivos para serem mensuráveis e significativos, considerando que as informações precisavam estar prontamente disponíveis e aptas ao monitoramento, sem riscos de constrangimentos técnicos, legais e econômicos.

O agrupamento dos dados ocorreu de acordo com as características de suas aplicações nos meios ambientais, sociais e econômicos. Cada dado foi considerado para determinar a extensão da relação com o plano local de desenvolvimento. Alguns dados foram usados mais de uma vez e às vezes em conjunto com outros dados para o monitoramento do desempenho ambiental.

Os temas para análise da sustentabilidade estão organizados em quatro categorias:

- Meio Ambiente

- Meio Físico

- Sociedade

- Economia 


\section{MEIO AMBIENTE}

Quanto ao meio ambiente, o caso de Mid Devon contempla os seguintes objetivos, indicadores e metas, em função dos critérios:

\subsection{BIODIVERSIDADE E CONSERVAÇÃO NATURAL}

\begin{tabular}{|l|l|}
\hline \multicolumn{2}{|c|}{ OBJETIVO } \\
\hline \multicolumn{2}{|c|}{ Proteger e melhorar a biodiversidade e os sítios significativos de conservação natural } \\
\hline \multicolumn{1}{|c|}{ INDICADORES } & \multicolumn{1}{c|}{ METAS } \\
\hline $\begin{array}{l}\text { áreas de importância ecológica e habitats } \\
\text { significativos que possuem designação } \\
\text { estatutária ou não }\end{array}$ & $\begin{array}{l}\text { manter ou aumentar o número de áreas } \\
\text { estatutárias ou não }\end{array}$ \\
\hline área total de tipos de habitats prioritários & $\begin{array}{l}\text { manter o número e as áreas totais de habitats } \\
\text { prioritários }\end{array}$ \\
\hline
\end{tabular}

Tabela 9 - Temas relativos à Conservação Natural (adaptado de MDDC, 2006)

\subsection{PATRIMÔNIO CULTURAL}

\section{OBJETIVO}

Proteger e aprimorar as questões/sítios arqueológicos e de importância histórica e material patenteado

\begin{tabular}{|l|l|}
\hline \multicolumn{1}{|c|}{ INDICADORES } & \multicolumn{1}{c|}{ METAS } \\
\hline número total de construções catalogadas & manter o numero total desta lista \\
\hline $\begin{array}{l}\text { número de prédios catalogados e prédios em } \\
\text { risco }\end{array}$ & reduzir este o número \\
\hline $\begin{array}{l}\text { número de cronograma de ações sobre } \\
\text { monumentos }\end{array}$ & manter este número \\
\hline número/área de parques históricos e jardins & manter número/área \\
\hline número de áreas de conservação - AC & manter ou aumentar AC \\
\hline número de AC oficiais & aumentar esse número \\
\hline
\end{tabular}

Tabela 10 - Temas relativos ao Patrimônio (adaptado de MDDC, 2006) 


\subsection{PAISAGEM}

\begin{tabular}{|c|c|}
\hline \multicolumn{2}{|c|}{ OBJETIVO } \\
\hline \multicolumn{2}{|l|}{ Proteger e melhorar a paisagem rural e urbana } \\
\hline INDICADORES & METAS \\
\hline $\begin{array}{l}\text { áreas de solo designadas pela sua qualidade } \\
\text { da paisagem natural/construída ou facilidades }\end{array}$ & $\begin{array}{l}\text { manter o total de áreas destinadas a paisagem } \\
\text { natural e manter ou aumentar o número de } \\
\text { áreas de conservação }\end{array}$ \\
\hline número de áreas de conservação instituídas & $\begin{array}{l}\text { aumentar o numero de áreas de conservação } \\
\text { oficiais }\end{array}$ \\
\hline número total de árvores e grupos de árvores & manter ou aumentar esse número \\
\hline áreas de florestas antigas e outras florestas & $\begin{array}{l}\text { manter o número de florestas antigas e } \\
\text { aumentar a área de outras florestas }\end{array}$ \\
\hline áreas de facilidades de espaço aberto & aumentar o número destas áreas \\
\hline áreas de parques históricos e jardins oficiais & $\begin{array}{l}\text { manter o número de parques históricos e } \\
\text { jardins }\end{array}$ \\
\hline
\end{tabular}

Tabela 11 - Temas relativos à Paisagem (adaptado de MDDC, 2006)

\section{RECURSOS NATURAIS}

Quanto aos recursos naturais, o caso de Mid Devon contempla os seguintes objetivos, indicadores e metas, em função dos critérios:

\section{1 ÁGUA}

\section{OBJETIVO}

Proteger e melhorar a qualidade de todos os recursos hídricos

\begin{tabular}{|l|l|}
\hline \multicolumn{1}{|c|}{ INDICADORES } & \multicolumn{1}{c|}{ METAS } \\
\hline $\begin{array}{l}\text { comprimento dos rios considerados bom ou } \\
\text { aquém das qualidades químicas e biológicas }\end{array}$ & $\begin{array}{l}\text { reduzir os trechos classificados como ruins e } \\
\text { estender a boa qualidade dos outros trechos }\end{array}$ \\
\hline
\end{tabular}

Tabela 12 - Temas relativos à Água (adaptado de MDDC, 2006) 


\subsection{CLIMA}

\section{OBJETIVO}

Mitigar e adaptar os fatores de mudanças climáticas

\begin{tabular}{|l|l|}
\hline \multicolumn{1}{|c|}{ INDICADORES } & \multicolumn{1}{c|}{ METAS } \\
\hline emissões de CO2 baseado na média nacional & reduzir as emissões \\
\hline números de construções em área de várzea & $\begin{array}{l}\text { reduzir o número dessas ocupações e } \\
\text { ocupações indutoras de represamento de água }\end{array}$ \\
\hline
\end{tabular}

Tabela 13 - Temas relativos ao Clima (adaptado de MDDC, 2006)

\subsection{QUALIDADE DO AR}

\section{OBJETIVO}

Proteger e melhorar a qualidade do ar

\section{INDICADORES}

números de áreas que recebem investimentos para a melhoria da qualidade do ar

Tabela 14 - Temas relativos à Qualidade do Ar (adaptado de MDDC, 2006)

\subsection{TERRA E SOLO}

\section{OBJETIVO}

Proteger e melhorar a qualidade da terra e do solo

\begin{tabular}{|l|l|}
\hline \multicolumn{1}{|c|}{ INDICADORES } & \multicolumn{1}{c|}{ METAS } \\
\hline número total de possíveis áreas contaminadas & reduzir esse número \\
\hline proporção de habitações em Brownfield & $\begin{array}{l}\text { aumentar a densidade de ocupação em } \\
\text { Brownfield }\end{array}$ \\
\hline
\end{tabular}

Tabela 15 - Temas relativos à Terra e Solo (adaptado de MDDC, 2006) 


\subsection{CONSUMO}

\section{OBJETIVO}

Promover a redução do consumo, reciclagem, reutilização e energias renováveis

\begin{tabular}{|l|l|}
\hline \multicolumn{1}{|c|}{ INDICADORES } & \multicolumn{1}{c|}{ METAS } \\
\hline $\begin{array}{l}\text { porcentagem da reciclagem dos moradores de } \\
\text { Mid Devon }\end{array}$ & $\begin{array}{l}\text { aumentar o número de adeptos ou atingir a } \\
\text { meta de 33\% em 2006 }\end{array}$ \\
\hline $\begin{array}{l}\text { quantidade do consumo gerado no distrito } \\
\text { pelo número de moradores ao longo do ano }\end{array}$ & reduzir este consumo \\
\hline
\end{tabular}

Tabela 16 - Temas relativos ao Consumo (adaptado de MDDC, 2006)

\subsection{TRANSPORTE}

\begin{tabular}{|c|c|}
\hline \multicolumn{2}{|l|}{ 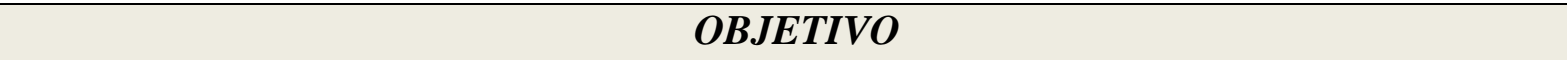 } \\
\hline \multicolumn{2}{|l|}{ Reduzir a necessidade de viagens } \\
\hline INDICADORES & METAS \\
\hline viagens para trabalho & $\begin{array}{l}\text { aumentar o uso do transporte coletivo, } \\
\text { caminhada e bicicleta }\end{array}$ \\
\hline $\begin{array}{l}\text { número de novas ocupações residenciais e } \\
\text { comerciais localizadas a } 500 \mathrm{~m} \text { dos pontos de } \\
\text { ônibus }\end{array}$ & estimular esse desenvolvimento \\
\hline $\begin{array}{l}\text { número de ocupações existentes a 500m dos } \\
\text { pontos de ônibus }\end{array}$ & $\begin{array}{l}\text { aumentar o número de propriedades servidas } \\
\text { pelo transporte coletivo }\end{array}$ \\
\hline $\begin{array}{l}\text { proporção de novos empreendimentos } \\
\text { localizados dentro e fora da fronteira }\end{array}$ & $\begin{array}{l}\text { aumento dos empreendimentos dentro da } \\
\text { fronteira }\end{array}$ \\
\hline
\end{tabular}

Tabela 17 - Temas relativos ao Transporte (adaptado de MDDC, 2006) 


\section{SOCIEDADE}

Quanto à sociedade, o caso de Mid Devon contempla os seguintes objetivos, indicadores e metas, em função dos critérios:

\subsection{PARTICIPAÇÃO E PRIVAÇÃO SOCIAL}

\section{OBJETIVO}

Aliviar a pobreza e aumentar a participação comunitária nas decisões do planejamento de uso do solo

\begin{tabular}{|l|l|}
\multicolumn{1}{|c|}{ INDICADORES } & \multicolumn{1}{c|}{ METAS } \\
\hline $\begin{array}{l}\text { índices do Deprivation Index of Multiple } \\
\text { Deprivation }\end{array}$ & reduzir a degradação \\
\hline responsabilidade das audiências públicas & $\begin{array}{l}\text { manter a consulta à comunidade apropriada e } \\
\text { a envolver na preparação de planos }\end{array}$ \\
\hline
\end{tabular}

Tabela 18 - Temas relativos à Participação (adaptado de MDDC, 2006)

\subsection{HABITAÇÃO}

\section{OBJETIVO}

Estimular que as demandas habitacionais da comunidade encontrem localmente boa qualidade para todos

\begin{tabular}{|l|l|}
\hline \multicolumn{1}{|c|}{ INDICADORES } & \multicolumn{1}{c|}{ METAS } \\
\hline proporção de habitação satisfatória & aumentar esse número \\
\hline preço das habitações & diminuição dos preços \\
\hline $\begin{array}{l}\text { proporção de novos empreendimentos dentro } \\
\text { dos limites dos assentamentos }\end{array}$ & aumentar esse número \\
\hline $\begin{array}{l}\text { proporção de novos empreendimentos com } \\
\text { acesso ao transporte público existente }\end{array}$ & aumentar esse número \\
\hline
\end{tabular}

Tabela 19 - Temas relativos à Habitação (adaptado de MDDC, 2006)

\subsection{SAÚDE E SEGURANÇA AMBIENTAL}

\section{OBJETIVO}

Garantir a saúde e a segurança no trabalho e condições ambientais aumentando a qualidade de vida para todos

\begin{tabular}{|l|l|}
\hline \multicolumn{1}{|c|}{ INDICADORES } & \multicolumn{1}{c|}{ METAS } \\
\hline $\begin{array}{l}\text { índices de degradação dominante e } \\
\text { subdomínios do exterior }\end{array}$ & diminuir a degradação \\
\hline $\begin{array}{l}\text { proporção de abrigo com acesso aos espaços } \\
\text { abertos }\end{array}$ & aumentar essa proporção \\
\hline
\end{tabular}

Tabela 20 - Temas relativos à Saúde (adaptado de MDDC, 2006) 


\subsection{ACESSO A FACILIDADES E SERVIÇOS}

\section{OBJETIVO}

Providenciar o suficiente e dar acesso aos cuidados de saúde, serviços comunitários e facilidades

\begin{tabular}{|l|l|}
\hline \multicolumn{1}{|c|}{ INDICADORES } & \multicolumn{1}{c|}{ METAS } \\
\hline $\begin{array}{l}\text { índices de barreira aos serviços sociais e } \\
\text { habitação com degradação dominante }\end{array}$ & reduzir esse nível \\
\hline $\begin{array}{l}\text { proporção de novos empreendimentos } \\
\text { habitacionais servidos de transporte público }\end{array}$ & $\begin{array}{l}\text { aumentar a proporção destes } \\
\text { empreendimentos localizados a 500m destes } \\
\text { transportes }\end{array}$ \\
\hline $\begin{array}{l}\text { proporção dos atuais núcleos residenciais } \\
\text { servidos de transporte público }\end{array}$ & $\begin{array}{l}\text { aumentar o número de propriedades } \\
\text { abrangidas pelo transporte público }\end{array}$ \\
\hline $\begin{array}{l}\text { comprimento total de vias peatonais, } \\
\text { ciclovias e de tração animal }\end{array}$ & manter ou aumentar esses caminhos \\
\hline $\begin{array}{l}\text { cartilhas de demanda } \\
\text { número e tipo de provimentos de saúde e } \\
\text { serviço social e facilidades oferecidas no } \\
\text { perímetro }\end{array}$ & $\begin{array}{l}\text { aumentar essa demanda e informar a } \\
\text { população }\end{array}$ \\
\hline $\begin{array}{l}\text { número de novos empreendimentos ou aumentar esse provimento } \\
\text { residenciais abastecidos por esses } \\
\text { provimentos }\end{array}$ & $\begin{array}{l}\text { aumentar a proporção destes } \\
\text { empreendimentos }\end{array}$ \\
\hline
\end{tabular}

Tabela 21 - Temas relativos aos Serviços (adaptado de MDDC, 2006)

\section{ECONOMIA}

Quanto à economia, o caso de Mid Devon contempla os seguintes objetivos, indicadores e metas, em função dos critérios:

\subsection{TURISMO}

\section{OBJETIVO}

promover a sustentabilidade do lazer e turismo e aumentar o número de visitantes

\begin{tabular}{|l|l|}
\hline \multicolumn{1}{|c|}{ INDICADORES } & \multicolumn{1}{c|}{ METAS } \\
\hline número de pernoites & $\begin{array}{l}\text { manter ou aumentar o número de visitantes } \\
\text { que passam a noite em Mid Devon }\end{array}$ \\
\hline capacidade de acomodação & manter ou aumentar esse número \\
\hline
\end{tabular}

Tabela 22- Temas relativos ao Turismo (adaptado de MDDC, 2006) 


\subsection{CRESCIMENTO ECONÔMICO}

\section{OBJETIVO}

Atrair novos investimentos e encorajar o crescimento econômico

\begin{tabular}{|l|l|}
\hline \multicolumn{1}{|c|}{ INDICADORES } & \multicolumn{1}{c|}{ METAS } \\
\hline índices de degradação e custeio & redução dos custos da degradação \\
\hline $\begin{array}{l}\text { número de registros administrativos dos } \\
\text { grupos industriais }\end{array}$ & manutenção e aumento desse número \\
\hline
\end{tabular}

Tabela 23 - Temas relativos ao Crescimento Econômico (adaptado de MDDC, 2006)

\subsection{DIVERSIFICAÇÃO URBANA E RURAL}

\begin{tabular}{|l|l|}
\hline \multicolumn{2}{|c|}{ OBJETIVO } \\
\hline \multicolumn{2}{|c|}{ Estimular a diversificação rural e urbana } \\
\hline \multicolumn{2}{|c|}{ INDICADORES } \\
$\begin{array}{l}\text { número de pequenos negócios baseados nos } \\
\text { registros de frequiência de empregos }\end{array}$ & $\begin{array}{l}\text { manutenção do número de pequenos negócios } \\
\text { e aumentar a diversidade de registros }\end{array}$ \\
\hline tipos de novos negócios & manter ou aumentar esse número \\
\hline $\begin{array}{l}\text { localização de novos negócios em perímetro } \\
\text { urbano e rural }\end{array}$ & $\begin{array}{l}\text { aumentar o número e o tipo do } \\
\text { desenvolvimento econômico nas áreas rurais }\end{array}$ \\
\hline
\end{tabular}

Tabela 24 - Temas relativos à Diversificação de Negócios (adaptado de MDDC, 2006)

\subsection{EMPREGO}

\begin{tabular}{|c|c|}
\hline \multicolumn{2}{|c|}{ OBJETIVO } \\
\hline Estimular a oportunidade e acesso aos emp & \\
\hline INDICADORES & METAS \\
\hline áreas de desemprego & reduzir os níveis destas áreas \\
\hline níveis de desemprego & manter ou reduzir esse número \\
\hline total de empregos & $\begin{array}{l}\text { aumentar o número e a diversidade dos } \\
\text { registros }\end{array}$ \\
\hline viagens para trabalho & $\begin{array}{l}\text { reduzir a proporção de pessoas viajando de } \\
\text { carro para trabalho }\end{array}$ \\
\hline $\begin{array}{l}\text { número de existentes e novas áreas de } \\
\text { emprego com acesso ao transporte público }\end{array}$ & aumentar esse número \\
\hline $\begin{array}{l}\text { número de existentes e novas áreas de } \\
\text { emprego dentro do perímetro }\end{array}$ & aumentar esse número \\
\hline
\end{tabular}

Tabela 25 - Temas relativos ao Emprego (adaptado de MDDC, 2006) 


\subsection{VENDAS}

\begin{tabular}{|c|c|}
\hline \multicolumn{2}{|c|}{ OBJETIVO } \\
\hline \multicolumn{2}{|c|}{ Promover a vitalidade e viabilidade das cidades e centros locais } \\
\hline INDICADORES & METAS \\
\hline número de lojas nos centros urbanos & $\begin{array}{l}\text { manter ou aumentar o número de lojas e } \\
\text { espaços disponíveis }\end{array}$ \\
\hline $\begin{array}{l}\text { número e tipos de vendas e facilidades } \\
\text { comerciais localizados no município }\end{array}$ & $\begin{array}{l}\text { manter ou aumentar essa diversidade de usos } \\
\text { nas áreas centrais e em outros vilarejos }\end{array}$ \\
\hline
\end{tabular}

Tabela 26 - Temas relativos às Vendas (adaptado de MDDC, 2006)

O relatório de AAE realizado para direcionar o planejamento de uso e ocupação do solo de Mid Devon é apresentado por meio de objetivos e indicadores de desempenho, que estão diretamente relacionados com suas respectivas metas. Ao adotar este sistema de acompanhamento, a evolução dos indicadores permite a participação do público leigo. No entanto, este modelo de apresentação já direciona as decisões, uma vez que as metas já foram estipuladas. Esse modelo de sistematização é mais indicado quando se busca uma estratégia de mudança do estado atual.

De acordo com os indicadores analisados, pode-se destacar a importância dada à adequação das pressões de crescimento de novos loteamentos e da diversidade de negócios com a infraestrutura existente. A preocupação em relacionar a localização dos pontos de ônibus e as rotas percorridas pelo transporte coletivo com a existência de novos loteamentos, ou de áreas disponíveis para novos loteamentos, alia questões de infraestrutura, como o próprio sistema viário e sua capacidade de suporte, a aspectos econômicos, como o custo de implantação de novos equipamentos e a necessidades de viajar, além ainda de questões climáticas, como a emissão atmosférica geradas pelo transporte rodoviário, e o consumo de áreas verdes relativos aos empreendimentos localizados fora da fronteira urbana.

Os indicadores adotados não estão limitados exclusivamente às questões do meio antrópico, mas sim utilizados de maneira estratégica para orientar as ações de novos empreendimentos, relacionando-se com a preservação dos recursos naturais em área rural. Os indicadores possibilitam o acompanhamento das ações pela população, sendo que os cuidados em quantificar as audiências públicas realizadas e a divulgação das demandas identificadas no diagnóstico ilustram a importância dada para o processo de participação. 
O relatório de AAE aplicado aos Planos de Uso e Ocupação do Solo permite a interação sinérgica dos diferentes temas, ilustrando as potencialidades da previsão dos impactos cumulativos e suas conseqüências em diferentes setores. Aspectos do meio antrópico são estrategicamente analisados frente ao meio físico e biótico. Este modelo de articulação das ações de planejamento poderia também ser aplicado no município de São Carlos, contribuindo desta maneira para uma visão mais abrangente das ações implementadas, além ainda de estimular a responsabilidade da participação popular, fortalecendo o processo de descentralização previsto no Estatuto da Cidade, implementado pelo Plano Diretor Municipal. 


\section{PLANEJAMENTO MUNICIPAL DE USO E OCUPAÇÃO DO SOLO}

A melhoria da capacidade de gerenciamento ambiental e a consolidação das instituições são vistas como pré-requisitos para a adequação das questões ambientais e para a criação de estratégias ambientais específicas para cidades. De acordo com Brand \& Thomas (2005), as cidades podem ser unidades efetivas de implementação de políticas ambientais, gerenciamento e inovação, já que administrativamente possuem limites espaciais em escala que facilita a compreensão das dificuldades dos problemas ambientais.

A escala municipal de gestão permite a integração de responsabilidades políticas dada à natureza dos problemas ambientais e a gestão viável desta aproximação com o planejamento de uso e ocupação do solo. Para Mol (1997), entre os avanços mais significativos estão à criação dos departamentos governamentais para o meio-ambiente, com expansão da legislação incidente e de planejamento, e um rápido aumento do número de organizações nãogovernamentais - ONGs - que participam das discussões do planejamento municipal.

Segundo Burgess (2000), a discussão entre os interessados para o direcionamento das iniciativas de crescimento coloca o reconhecimento do contexto local como uma questão fundamental para o debate ambiental nas cidades. A função do processo de planejamento é garantir que a grande variedade de interesses seja considerada e que os benefícios estejam relacionados com o interesse público em geral, considerando a necessidade de atendimento a vários interesses.

Uma das razões para o crescimento da importância aos processos de planejamento e das descentralizações nas decisões junto ao envolvimento popular está na possibilidade de que eles serão efetivos na redução do conteúdo dos conflitos futuros. No entanto, segundo Paoli (2002), os dispositivos de participação popular voltados às formas democráticas de discussão e deliberação podem ser eles próprios constituídos previamente por desenhos técnicos que delimitem a espontaneidade do debate e previnam transbordamentos indesejáveis. Para Villaça (2005), os espaços de discussão, tradicionalmente no Brasil, quando criados são utilizados por aqueles atores que já possuem estrutura de participação, geralmente os grupos melhor organizados e financeiramente mais fortalecidos.

Assim, é importante o estabelecimento de critérios claros construídos durante o processo de planejamento, pois sem eles será difícil controlar as mudanças das circunstâncias. Durante o processo de planejamento deverão ser acordados planos e outros documentos oficiais que gerem um ponto de referência para aquelas propostas que precisam ser mensuradas. Segundo Miller et al. (apud MONTEIRO, 1975), plano pode ser definido como 
um processo hierárquico no interior de um organismo que possa controlar a ordem por meio da qual uma seqüência de operações deva ser empenhada.

Para Cullingworth \& Nadin (2002), existem grupos com opiniões divergentes sobre quais as teorias e procedimentos do sistema de planejamento. O conceito de planejamento participativo é feito numa contextualização de políticas de tempo e lugar, diante da opinião popular e sua aceitabilidade ou outros tipos de ações governamentais. Os chamados incrementalistas procuram trocar os grandes planos por aproximações de passo-a-passo, os quais têm como objetivo alcançar melhorias realizáveis na situação existente, sendo um método de comparações limitadas dos problemas circunscritos e ações para negociar com eles.

O planejamento pode se transformar de uma preocupação com grandes planos para os de procedimentos de encontrar maneiras de conciliar conflitos de interesses que são afetados pelo desenvolvimento. Paradoxalmente, isso acontece num mesmo tempo em que os governos estão tentando garantir um maior grau de segurança sobre o controle do uso e ocupação do solo pelos sistemas de planos diretores, formulados para a negociação e mediação. Segundo Cahn (1995), as elites políticas, na tentativa de resolverem os problemas ambientais com crescimento econômico, reduzem a complexidade das variáveis ambientais à simples relações, sugerindo uma modesta regulação com substancial crescimento. A demanda pública pelas questões ambientais é então relativamente satisfeita com uma regulação branda.

\subsection{USO E OCUPAÇÃO DO SOLO NA CONSTITUIÇÃO FEDERAL DO BRASIL}

O fenômeno urbano acarretou um crescimento desordenado nas cidades e afetou a qualidade de vida nos espaços urbanos. Segundo Jacobi (1996), o fato de a América Latina apresentar quase $65 \%$ da população vivendo nas cidades revela a prioridade do planejamento urbano no enfrentamento da questão ambiental, sobretudo quando se observa a relação entre degradação do meio ambiente e carência de infraestrutura, o que sugere uma grande preocupação e atenção com a busca da qualidade de vida nas cidades.

Segundo Pires (2007), dentro do contexto da crescente urbanização, a política urbana mereceu relevo e destaque já na Constituição Federal do Brasil de 1988 - CF, ganhando capítulo próprio, objetivando ordenar o pleno desenvolvimento das funções sociais das

cidades e a garantia do bem-estar de seus habitantes. A norma constitucional objetiva a proteção do ser humano, definindo o meio ambiente como essencial à qualidade de vida. Assim, toda a política de desenvolvimento urbano deve ser balizada pelos caminhos da 
proteção ambiental, como meio de garantir a qualidade de vida de seus habitantes. Quanto à política ambiental aplicada em área urbana, deve ser norteada pela ordenação adequada dos espaços habitados.

A Constituição Federal trata do tema função social da propriedade em diversos momentos: no Título II referente aos Direitos e Garantias Individuais, em seu o artigo V, inciso XXIII; no Título VII, referente à ordem econômica e financeira, que no Capítulo I, artigo 170, inciso III, entre os princípios gerais da atividade econômica está a garantia de atendimento da função social da propriedade. No mesmo Título, Capítulo II, referente à política urbana, o artigo 182, parágrafo $2^{\circ}$, que traduz a função social da propriedade municipal, bem como o caput traz a função social da cidade. Também no Capítulo III, referente à política agrícola e fundiária e da reforma agrária, no artigo 184 atribui a competência para a União, a desapropriação da propriedade rural que não esteja cumprindo sua função social, definindo no artigo 186 quando a função social é cumprida nas propriedades rurais, isto é, quando atender simultaneamente ao aproveitamento racional e adequado, a utilização adequada dos recursos naturais disponíveis e a preservação do meio ambiente.

Portanto, a função social da propriedade é um dever. O seu descumprimento estará sujeito à sanção, sendo que o proprietário não possui apenas o dever de não exercitar seu direito em detrimento de outrem, possui, de modo correlato, o dever de exercitar aquele direito em favor de outrem. Para Pires (2007), a função social da propriedade está diretamente ligada à concretização da justiça social.

A CF determinou que a função social da propriedade municipal fosse delineada por meio do respectivo Plano Diretor, bem como estabeleceu as devidas sanções em caso de seu descumprimento. O planejamento ganhou relevo e destaque na nova ordem constitucional do Brasil. As normas do plano devem ser direcionadas e condicionadas a um tratamento igual para todos, não podendo beneficiar grupos ou interesses particulares. Atualmente, o Plano Diretor é regulamentado pela Lei Federal 10.257 de 2001, também denominada Estatuto da Cidade. 


\subsection{ESTATUTO DA CIDADE}

O presente capítulo tem como objetivo uma sucinta revisão do tema e pontuar alguns aspectos considerados mais relevantes para a discussão da aplicação nos casos apresentados.

A trajetória da elaboração do Estatuto da Cidade, de acordo com Braga \& Carvalho (2000), se iniciou pelo Senado como Projeto de Lei 5.788 de 1990. Em seguida tramitou na Câmara dos Deputados até 1997, quando conseguiu sua primeira aprovação na Comissão de Economia, Indústria e Comércio. No ano seguinte foi também aprovado pela Comissão de Defesa do Consumidor, Meio Ambiente e Minorias, e chegou em 1998 na Comissão de Desenvolvimento Urbano e Interior, sendo aprovado em 1999. O projeto foi encaminhado para a Comissão de Constituição, Justiça e Redação, sendo aprovado em 2000, encerrando sua tramitação na Câmara dos Deputados, retornando ao Senado para a apreciação final.

Segundo Silva (2006), o Estatuto da Cidade, instituído pela Lei 10.257 de 2001, estabelece diretrizes gerais da política urbana ao regulamentar os artigos 182 e 183 da CF. O Estatuto da Cidade reafirma o Plano Diretor como instrumento básico da política de uso e ocupação do solo municipal, devendo estabelecer os objetivos buscados, o prazo em que estes devem ser alcançados, as atividades a serem executadas e quem deve executá-las. É considerado diretor por fixar as diretrizes do uso e ocupação do solo do município, sendo que a sua elaboração deve atender as seguintes etapas:

- ESTUDOS PRELIMINARES: avaliam de forma sumária a situação e os problemas de uso e ocupação do solo do município, estabelecem as características e o nível de profundidade dos estudos subseqüentes, estabelecendo assim a política de planejamento municipal.

- DIAGNÓSTICO: pesquisa e análise em profundidade dos problemas de uso e ocupação do solo municipal selecionados na etapa anterior, identificando as variáveis que devem ser consideradas para as soluções desses problemas e prevê as perspectivas de evolução.

O diagnóstico deve determinar os problemas existentes na área a ser transformado, referentes aos bens ou serviços que a entidade pública se propõe colocar à disposição da comunidade local, assim como os problemas concernentes à estrutura institucional do município e sua adequação orgânico-administrativa para o cumprimento dos objetivos, procurando indicar as ações que devem ser empreendidas 
para seu atendimento, segundo uma escala de prioridade que seja estabelecida, os tipos de atuação para atender às necessidades identificadas e, assim, resolver os problemas existentes de acordo com os objetivos definidos.

O diagnóstico compreende duas partes: a primeira consiste numa análise retrospectiva da situação existente, em que se procura identificar os principais problemas e suas causas; a segunda configura uma análise projetiva, em que devem ser salientados os meios necessários a utilizar para a solução dos problemas verificados, de acordo com as diretrizes gerais estabelecidas, com vistas ao atendimento das necessidades constatadas.

- PLANO DE DIRETRIZES: estabelece uma política para as soluções dos problemas escolhidos e fixa os objetivos e diretrizes da organização territorial. O plano de diretrizes visa estabelecer o conjunto de orientação a ser seguida na solução dos problemas identificados. Baseado no diagnóstico é necessário fixar as diretrizes gerais, que consistem na determinação dos rumos que a entidade pretende trilhar em cada área específica, em face da situação levantada, cujo objetivo é dar atendimento através do estabelecimento de metas a serem atingidas, bem como na seleção dos meios para atingi-las.

- INSTRUMENTAÇÃO DO PLANO: compreende a elaboração dos instrumentos de atuação, de acordo com as diretrizes estabelecidas, e identifica as medidas capazes de atingir os objetivos escolhidos. A instrumentação do plano consiste na elaboração dos instrumentos de atuação, de acordo com as diretrizes estabelecidas, e identifica as medidas capazes de atingir os objetivos previstos, tratando-se do plano propriamente dito.

Segundo Pires (2007), o instrumento jurídico apropriado para a edição do Plano Diretor é a Lei, decisão do Poder Legislativo e não somente decisão do chefe do Executivo. O plano é a conseqüência de um planejamento que possui um caráter multidisciplinar, que deve envolver vários setores e profissionais técnicos.

Por expressa disposição legal, disciplinada no artigo 40, parágrafo $4^{\circ}$, inciso I do Estatuto da Cidade, a participação popular e de associações representativas da comunidade está prevista por meio das audiências públicas, no processo de aprovação da instrumentação do plano e no momento de sua fiscalização. Como regra procedimental tem, ainda, as 
referentes ao princípio da publicidade com a garantia à divulgação dos documentos produzidos e acesso de qualquer interessado a tais documentos. Segundo o Estatuto da Cidade seria nula a Lei que instituísse o Plano em desacordo com o disposto nos parágrafos $4^{\circ}$ e $5^{\circ}$ do art. 40, ou seja, ao atendimento da participação popular, a publicidade dos documentos e informações produzidas e o acesso de qualquer interessado aos documentos e informações.

O Estatuto da Cidade transformou a necessidade de adaptação das políticas públicas em dever, na medida em que o artigo 40 Parágrafo $3^{\circ}$ determinou que a lei que instituir $o$ Plano Diretor deverá ser revista, pelo menos, a cada dez anos. Considerando a dinâmica das situações planificadas, bem como das modificações das situações oriundas da dinâmica social e econômica, o plano não pode ser estático. Assim, as normas estabelecidas em determinado momento e sob certas circunstâncias devem ser objeto de revisão.

O Capítulo III do Estatuto da Cidade é dedicado inteiramente ao Plano Diretor, previsto como obrigatório pelo art. 182 da CF para cidades com mais de vinte mil habitantes. Somente após o Estatuto da Cidade se concretiza tal obrigatoriedade, por duas disposições:

1. A que faz incidir sobre o chefe do Poder Executivo Municipal a sanção de improbidade administrativa, caso não sejam tomadas as providências para que o Plano Diretor esteja aprovado em até cinco anos após a entrada em vigor da Lei (art. 52 e inciso VII).

2. A que acresce como objeto da Ação Civil Pública e como motivo da ação cautelar respectiva a ordenação urbanística, propiciando ao Ministério Público ou entidade com mais de um ano de existência, a possibilidade de, em liminar ou no mérito, obrigar (com base no art. $3^{\circ}$, da Lei 7347/85) a Câmara Municipal a aprovar o Plano Diretor, se decorrido os cinco anos.

Segundo Silva (2006), o plano de ação do chefe do Poder Executivo Municipal deve ser flexível, com diversas alternativas que poderão servir de balizamento indicativo de sua atuação a curto e médio prazo. Assim, o Plano Diretor, levando em conta os aspectos físico, social, econômico e administrativo institucional, deveria conter disposições e diretrizes gerais, fixando não uma, mas várias alternativas, como as normas discricionárias, que deixam ao administrador público a liberdade de escolha do caminho a seguir para atender da melhor forma o bem comum. 
O Estatuto da Cidade, se utilizado adequadamente, poderá corrigir ou colaborar para a correção da exclusão social e de outras mazelas do uso e ocupação do solo municipal. No entanto, segundo Stephan (2007), as normas do Plano Diretor formam um conjunto normativo intermediário, isto é, sua efetiva implementação depende de leis posteriores referentes a vários setores. Para Séguin (2002), a falta de entrosamento entre os vários setores envolvidos acarreta que aspectos fundamentais deixem de ser convenientemente avaliados, originando repercussões ambientais, sociais e urbanísticas.

A ação da gestão integrada entre vários setores e níveis de governo, segundo Maricato (1994), vem sendo adotada nos anos recentes pela eleição de governos municipais, contrariando a ação de desenvolvimento concentrado que acarreta o crescimento da desigualdade e da ilegalidade no uso e ocupação do solo. O modelo de desenvolvimento concentrado é caracterizado por uma interação entre processos socioeconômicos, opções de planejamento e práticas políticas que constituem um modelo excludente. A falta de uma política integrada e preventiva de uso e ocupação do solo e de investimentos para o atendimento às necessidades sociais e de infraestrutura conduziram a uma profunda degradação do ambiente urbano (MARICATO, 2001).

\subsection{PLANO DIRETOR MUNICIPAL}

Segundo Mukai (2002), o Plano Diretor apresenta como conteúdo um conjunto de normas legais, além de diretrizes, objetivos, programas e metas, abrangendo o desenvolvimento econômico-social, o meio ambiente e o uso e ocupação do solo, projetados para um determinado período. O Plano Diretor deve ser complementado e concretizado por diversas leis específicas como a de zoneamento, de parcelamento do solo, de proteção ambiental e da paisagem urbana.

Segundo Silva (2006), a concepção do Plano Diretor evoluiu. No período anterior a década de 1960, o Plano Diretor preocupava-se com o desenho da cidade, sua elaboração significava a aprovação de traçados de ruas e o estabelecimento dos lugares onde os edifícios públicos deveriam decorar a cidade, sendo que o valor fundamental a realizar e a preservar era o da estética urbana. Posteriormente, dedicava-se a estabelecer a distribuição das edificações no território, atendendo a funções econômicas e arquitetônicas. Mais tarde desenvolveu-se a concepção do Plano Diretor de Desenvolvimento Integrado com instrumento de planejamento municipal destinado a alcançar objetivos integrados nos campos físico, econômico, social e administrativo. 
O Plano Diretor de Desenvolvimento Integrado partiu da concepção do SERFHAU Serviço Federal de Habitação e Urbanismo -, criado pelo art. 54 da Lei 4.380/64, continha componentes que teriam que conduzir à implementação de um sistema de planejamento local integrado por uma entidade federal, além do desenvolvimento de uma metodologia de planejamento local que integrasse os aspectos econômicos e sociais da cidade, que era vista como um organismo autárquico, onde as ligações com outras cidades e regiões praticamente não eram levadas em consideração.

Atualmente, para que um processo de planejamento permanente seja considerado adequado à realidade do município, é necessária a observância de alguns princípios básicos, como a complementaridade e integração de políticas, planos e programas setoriais, respeito e adequação à realidade regional além da local, consonância com os planos e programas estaduais e federais existentes e possibilidade de democratização e acesso às informações disponíveis. O planejamento deve então considerar a sistematização interurbana no nível nacional, regional, estadual e intra-urbano no nível local, ou seja, deve levar em conta o mapeamento nacional no desenvolvimento do planejamento regional e estadual. Do mesmo modo o planejamento local não pode estar dissociado daqueles, caso contrário continuará com a falta de comunicação e ausência de concatenação de atos, o que resulta no prejuízo do desenvolvimento sustentável (SILVA, 2006).

Assim, de acordo com a CF (1988) e Estatuto da Cidade (2001), o Plano Diretor cumpre a função de instrumento de política urbana, envolvendo o uso e ocupação do solo do município. Era antes uma sistematização de áreas urbanas, preocupando-se com o interior das cidades. Agora deve abranger todo o território municipal, como a cidade e campo, área urbana e rural, sendo elemento indissociável e integrativo da unidade constitucional primária que é o Município.

O Poder Executivo Municipal detém a competência para realizar a política de uso do solo municipal, possuindo um papel de grande relevo na concretização da organização dos espaços da cidade, tendo por finalidade garantir a existência digna da população em seu território administrativo, bem como a condição de materializar os objetivos fundamentais do Estado, estampados no artigo $3^{\circ}$ da Constituição Federal, que objetiva a redução das desigualdades sociais.

A articulação entre município e Estado para a execução das políticas públicas é uma necessidade frente às várias situações presentes na cidade. No sentido de garantir a melhora da qualidade de vida, as políticas setoriais de habitação, transporte e saneamento necessitam de integração e cooperação entre os diferentes níveis de governo. O Plano Diretor tem por 
finalidade o adequado ordenamento do território do município com o objetivo de disciplinar o uso e ocupação do solo, isto é, a instrumentação de uma estratégia de mudança no sentido de obter a melhoria da qualidade de vida da comunidade local.

Segundo Mukai (2002), no Brasil o Plano Diretor é o instrumento técnico-legal definidor dos objetivos de cada municipalidade e com supremacia sobre os outros instrumentos de planejamento municipal, na medida em que orienta a atividade da administração e dos administrados nas realizações públicas e particulares que interesse ou afetem a comunidade. $\mathrm{Na}$ fixação dos objetivos e na orientação do desenvolvimento do município, o Plano Diretor é a lei suprema e geral que estabelece as prioridades nas realizações do governo local, conduz e ordena o crescimento da cidade, disciplina e controla as atividades urbanísticas em benefício do bem-estar social.

O Plano Diretor é, assim, um dos principais instrumentos da política de uso e ocupação do solo, nos termos do que dispõe o Estatuto da Cidade no art. $4^{\circ}$, inciso III, que prevê como instrumentos do planejamento municipal, entre outros, o Plano Diretor e o zoneamento ambiental.

O zoneamento de uso e ocupação do solo se configura como um plano específico, o Plano de Zoneamento, destinado a realizar na prática as diretrizes de uso estabelecidas no plano geral, o Plano Diretor. O zoneamento constitui procedimentos que tem por objetivo regular o uso da propriedade do solo e dos edifícios em áreas homogêneas, no interesse do bem-estar da população. A permissão de maior ou menor intensidade de uso nas diversas zonas é que proporciona o estabelecimento das densidades desejáveis de população e edificação. As normas e critérios de zoneamento devem ser fixados por lei municipal, tratando da legítima restrição ao direito de propriedade e ao direito de construir, estabelecido em face do interesse público, não dando direito a indenização dada à sua natureza de restrição geral (SILVA, 2006). 


\section{ESTUDO DE CASO: GERENCIAMENTO AMBIENTAL E O PLANO DIRETOR MUNICIPAL DE SÃO CARLOS}

O modelo de planejamento urbano realizado nas cidades brasileiras envolve a variável ambiental, que é também gerenciada por diferentes escalas e níveis de governo. Na presente pesquisa, foi selecionado o município de São Carlos, no interior do Estado de São Paulo, como caso de estudo para analisar a atuação do Plano Diretor Municipal, confrontando as temáticas abordadas por este instrumento com os problemas e potencialidades ambientais da área.

A descrição das bacias hidrográficas é importante para diagnosticar os recursos naturais e a situação ambiental em questão. Associada a estas informações, uma breve descrição do processo histórico de desenvolvimento do município auxilia na compreensão da forma como os valores ambientais foram influenciados pelo uso e ocupação do solo e o seu processo de planejamento.

Os temas abordados pelo Plano Diretor Municipal de São Carlos são confrontados com os temas presentes nos relatórios de AAE realizados para avaliar o uso e ocupação do solo das regiões de Monção e Mid Devon. As experiências internacionais de realização da AAE para os planos de uso e ocupação do solo serviram de base para identificar as possíveis melhorias no processo de planejamento municipal.

A possibilidade de aplicação de AAE no contexto do município de São Carlos foi analisada frente ao arcabouço legal presente no país. Deste modo, foi possível identificar oportunidades de melhoria no sistema de gestão ambiental brasileiro frente às experiências internacionais. Foram ainda realizadas considerações aos assuntos que poderiam influenciar a sustentabilidade do uso e ocupação do solo no município de São Carlos, além das contribuições que os procedimentos de AAE podem trazer ao Plano Diretor Municipal.

\subsection{AS BACIAS HIDROGRÁFICAS}

O Estado de São Paulo foi subdividido em 27 Unidades de Gerenciamento de Recursos Hídricos - UGRHIs. O município de São Carlos possui parte do seu território na Sub-Bacia Hidrográfica Tietê-Jacaré e parte na Sub-Bacia Hidrográfica Mogi-Guaçu.

A Bacia do rio Tietê é subdividida em 6 sub-bacias como UGRHI, distribuídas como: Piracicaba/Capivari/Jundiaí - UGHRI 5; Alto Tietê - UGRHI 6; Tietê/Sorocaba - UGRHI 10; Tietê/Jacaré - UGRHI 13; Tietê/Batalha - UGRHI 16 e Baixo Tietê - UGRHI 19. A sub- 
bacia Tietê Jacaré - UGRHI 13, ilustrada na Figura 10, gerencia a sub-bacia do rio JacaréPepira, parte da sub-bacia do rio Jacaré-Guaçu e porções de áreas drenadas para um trecho do Rio Tietê. (DAEE, 2007).

Segundo DAEE (1990), os municípios de Bauru, com aproximadamente 361 mil habitantes, Araraquara com aproximadamente 201 mil habitantes, e São Carlos com aproximadamente 226 mil habitantes, são as principais cidades desta Unidade Hidrográfica. A rodovia Washington Luís ao Norte, a Marechal Rondon ao Sul e a Hidrovia do Tietê entre as barragens de Barra Bonita e Ibitinga na parte Centro-Sul formam o principal sistema viário. Os campi da Universidade de São Paulo - USP, Universidade Estadual Júlio de Mesquita Filho - UNESP e Universidade Federal de São Carlos - UFSCar representam o setor educacional público de nível superior.

Segundo DAEE (2007), a bacia apresenta áreas críticas com relação ao risco de poluição das águas subterrâneas, na região de Bauru, Araraquara, Brotas e arredores. A bacia possui 19 municípios com índice de perdas nos sistema de abastecimento de água acima de $30 \%$. Há riscos de rebaixamento acentuado da superfície do lençol subterrâneo nas áreas urbanas de Bauru e Araraquara.

Em 1998, dentre os 32 municípios constituintes da região (com uma população total aproximada de 1.324 .000 habitantes), 40\% deles destinavam resíduos sólidos domiciliares em condições inadequadas, $40 \%$ em condições controladas e $20 \%$ em condições adequadas. Quanto às quantidades geradas, 22\% apresentavam condições inadequadas, $12 \%$ condições controladas e $66 \%$ condições adequadas. A bacia apresenta baixo índice de tratamento de esgoto doméstico, com lançamentos in natura nos corpos de água. Verifica-se alto potencial de carga orgânica industrial, devido essencialmente ao setor sucroalcooleiro.

A cana de açúcar, os citros e a pecuária são as principais atividades agrícolas. As indústrias sucroalcooleiras, sucocítricas, alimentícias e mecânica representam o parque industrial da região. Crítica em termos de disponibilidade hídrica superficial, a UGRHI 13 apresenta demandas elevadas de recursos hídricos devido à irrigação e ao setor sucroalcooleiro, notadamente nas microbacias do médio Jacaré-Guaçu e ribeirão dos Lençóis.

A UGRHI 13, onde se situa parte do município de São Carlos, é objeto de estudos visando orientar medidas corretivas e preventivas de controle de erosão e assoreamento. Apresenta de média a alta suscetibilidade a inundações nas sub-bacias dos rios Jacaré-Guaçu e Jacaré-Pepira, com agravamento nas áreas urbanizadas, apresentando média a alta suscetibilidade a erosão nas cabeceiras do rio Jacaré-Pepira. 
S

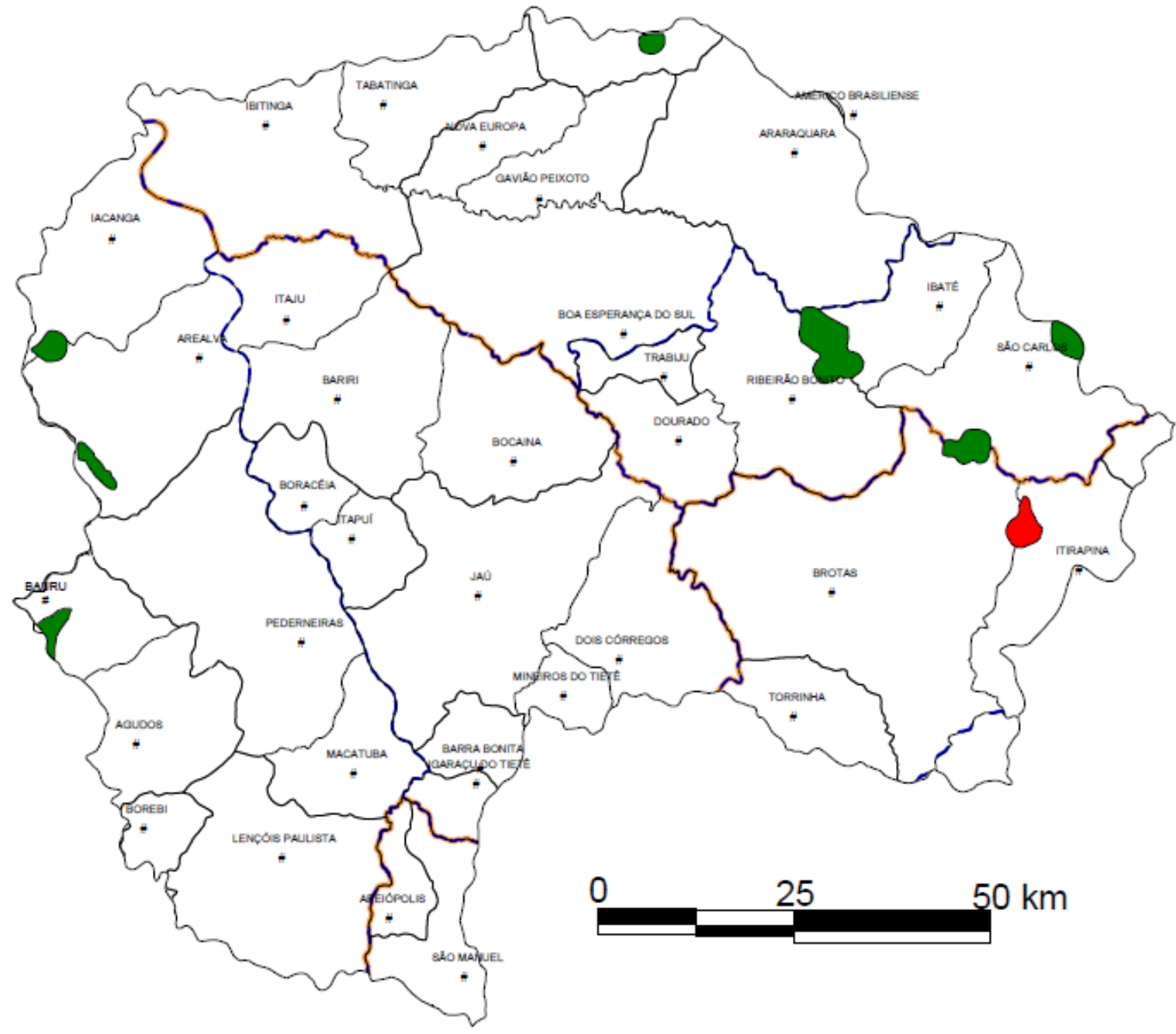

Itirapina : cerrado e campo cerrado

- Nothura minor (codorna buraqueira)

Chysocyon brachyurus (lobo-guará)

Áreas com fragmentos significativos e/ou

de singularidade ecológica

M Limite de região administrativa.

, Limite de região de governo.

Figura 10: UGRHI da Bacia Tietê-Jacaré.

(fonte:http://www.sigrh.sp.gov.br/sigrh/ARQS/RELATORIO/CRH/CBH-

TJ/1093/tjfig5.6.pdf) 
A Bacia Hidrográfica do Rio Grande é dividida em 6 sub-bacias: Mantiqueira UGRHI 1, Pardo - UGHRI 4, Sapucaí-Grande - UGRHI 8, Mogi-Guaçu - UGRHI 9, Baixo Pardo-Grande - UGRHI 12 e Turvo-Grande - UGRHI 15. A sub-bacia Mogi-Guaçu UGRHI 9 gerencia a sub-bacia do rio Mogi-Guaçu.

A UGRHI 9, ilustrada na Figura 11 e onde se situa parte do município de São Carlos, é composta por 38 municípios e possui uma população de 1.292.883 habitantes (IBGE, 2000), apresentando como principais atividades econômicas as fecularias, laticínios, frigoríficos e matadouros, usinas, engenhos e destilarias, curtumes, indústria de papel e celulose e metalúrgicas.

Segundo DAEE (1999), a Bacia é crítica em termos de disponibilidade hídrica superficial, com demandas elevadas devido à irrigação e ao setor sucroalcooleiro, principalmente no Alto Mogi e Jaguari-Mirim. Apresenta ainda uso consuntivo elevado e criticidade com relação ao risco de poluição das águas subterrâneas na área de recarga do sistema aquífero Guarani. Além disso, apresenta também contaminação dos corpos de água devido ao uso de agrotóxicos, sendo que cerca de $25 \%$ dos municípios necessitam de intervenções para adequar suas disposições atuais de resíduos sólidos e também, quando for o caso, a recuperação de antigos lixões e de solução para os passivos ambientais existentes.

A UGRHI possui 23 municípios com índice de perdas no sistema de abastecimento acima de 30\%. Apenas um município apresenta índice de abastecimento de água inferior a 80\%. Em 1998, 43\% dos municípios depositavam resíduos sólidos domiciliares em instalações inadequadas, $14 \%$ em condições controladas e $43 \%$ em condições adequadas. A UGHRI apresenta baixo índice de remoção da carga orgânica de origem doméstica, em virtude de a maioria dos municípios não disporem de sistemas de tratamento. Dos 38 municípios somente cinco tratam integralmente seus esgotos. Verifica-se alto potencial de carga orgânica industrial devida essencialmente ao setor sucroalcooleiro.

Apesar de possuir 7 Unidades de Conservação, apenas 5\% de sua área está preservada por vegetação nativa. Os principais problemas da UGHRI 9, segundo DAEE (1999), estão na baixa cobertura vegetal nativa, baixo índice de tratamento de esgotos, forte tendência de concentração urbana com os consequentes problemas de gestão dos recursos hídricos e poluição ambiental. A taxa de mortalidade infantil registra nível acima da média do Estado.

Os setores críticos relacionados à erosão são pouco expressivos na área. Há média suscetibilidade a inundações ao longo do rio Mogi-Guaçu e alta suscetibilidade em alguns de seus afluentes em trechos urbanos. 
$\sum_{n}^{5} \sum_{n}^{8}=$

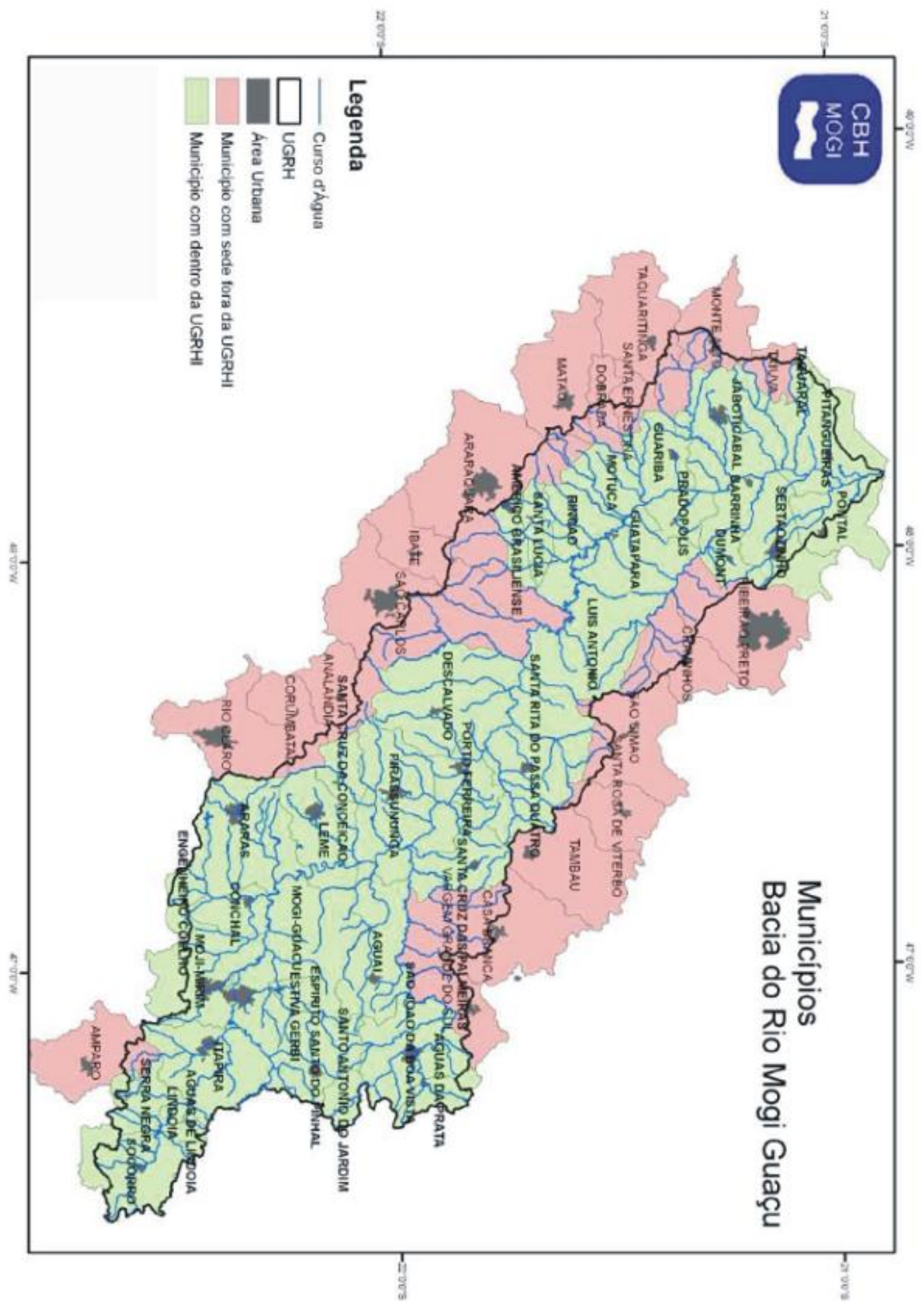

Figura 11: UGRHI da Bacia Mogi-Guaçu.

(fonte:http://www.sigrh.sp.gov.br/sigrh/ARQS/RELATORIO/CRH/CBHMOGI/1308/planocbhmogi_parte2.pdf) 


\subsection{O MUNICÍPIO DE SÃO CARLOS}

Assim como na maior parte da história da formação das cidades paulistas, São Carlos teve sua origem pautada na economia agrícola, inicialmente com o cultivo da cana-de-açúcar e posteriormente recebeu grande impulso com a economia cafeeira. Segundo Truzzi (2000), fazendas de café propiciavam o crescimento econômico da região, concentrando a maior parte do poder econômico na lavoura agrícola e consequente ênfase em sua área rural. De acordo com Devescovi (1987), em 1884 é construído o primeiro edifício público da cidade, prédio da Câmara Municipal, erguido perpendicular a então Rua São Carlos, fundando o Largo Municipal.

Segundo Fabbro Neto (2004), os investimentos realizados no núcleo urbano qualificavam os espaços voltados às reuniões sociais e políticas da elite cafeeira, que foi sucedido por uma série de investimentos por parte do poder público municipal. Em 1892 é construído o Theatro São Carlos, em 1900 é inaugurado o edifício do Fórum e a Cadeia com sua fachada principal voltada para o Largo Municipal. Em 1914 é inaugurado o bonde elétrico ratificando o poderio econômico da cidade, segundo Fabbro Neto (2004).

A crise do café do final da década de 1920 atingiu a pujança econômica da cidade, momento em que o desenvolvimento urbano deixa de se refletir nas construções e passa a ser notado na diversidade de comércio e serviços, originários da nova forma de trabalho imigrante, mão de obra então dispensada da lavoura cafeeira. A estagnação econômica contribuiu para que as construções do centro fossem mantidas, sendo que um novo significativo impulso da infraestrutura urbana voltasse a ocorrer no município com a chegada da Universidade de São Paulo - USP em 1948, e novo estímulo em 1970 com a criação da Universidade Federal de São Carlos - UFScar na extremidade Norte da cidade, conforme o Figura 12. 


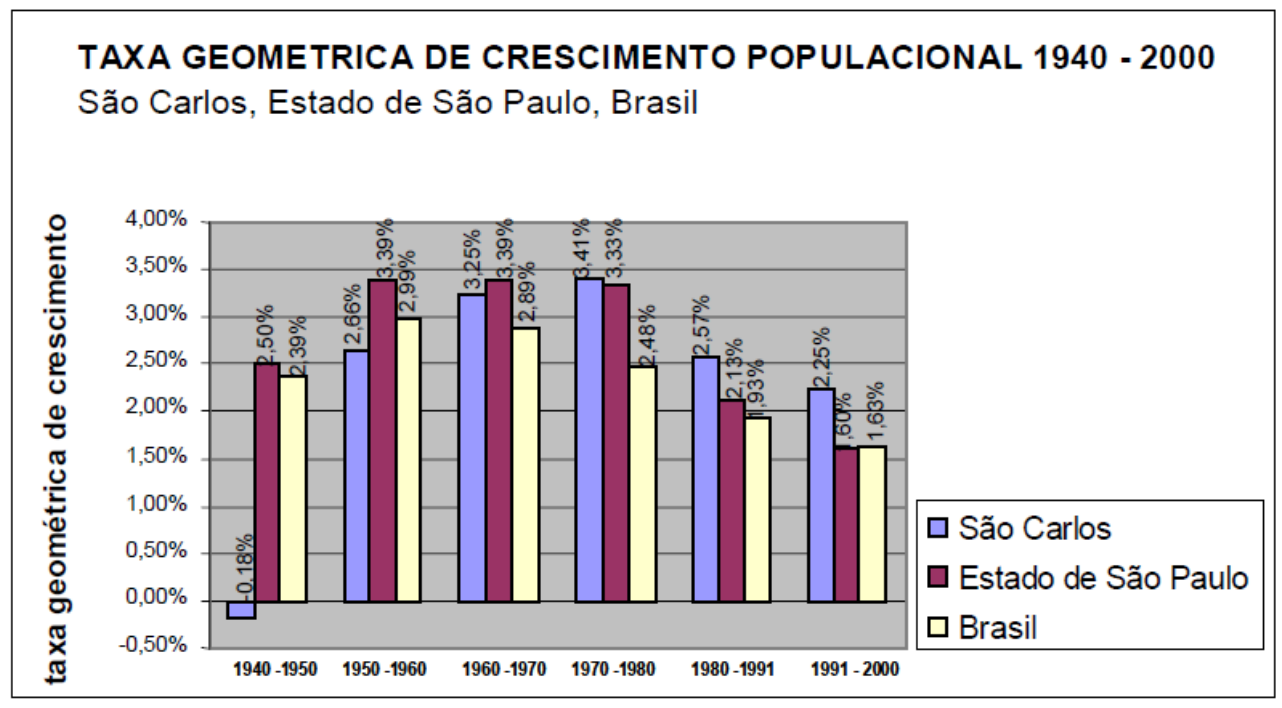

Fonte: IBGE

Figura 12 - Taxa Geométrica de Crescimento Populacional (PMSC, 2003)

Até 1950 a população de quase 50.000 habitantes se concentrava na área central, sendo que em 1970 é registrado um aumento para mais de 85.000 habitantes com forte predominância de ocupação na área norte da cidade, segundo a Conferência da Cidade (PMSC, 2003), realizada pela Prefeitura Municipal em função da elaboração do Plano Diretor do Municipal. A ocupação da área urbana ocorreu de forma descontínua e fragmentada, conforme a Figura 13.

Segundo PMSC (2003), a cidade cresceu sobre áreas inadequadas, com problemas de erosão, de drenagem e de proteção de encostas e mananciais. Foi a partir dos anos 70 que o conflito entre a expansão urbana e as áreas ambientalmente frágeis se acentuou, principalmente com implantação de vias marginais e a invasão de áreas de proteção ambiental à beira de córregos. 


\begin{tabular}{l|l}
\hline até 1940 & 1970 a 1980 \\
\hline 1940 a 1950 & 1980 a 1990 \\
1950 a 1970 & 1990 a 2002
\end{tabular}

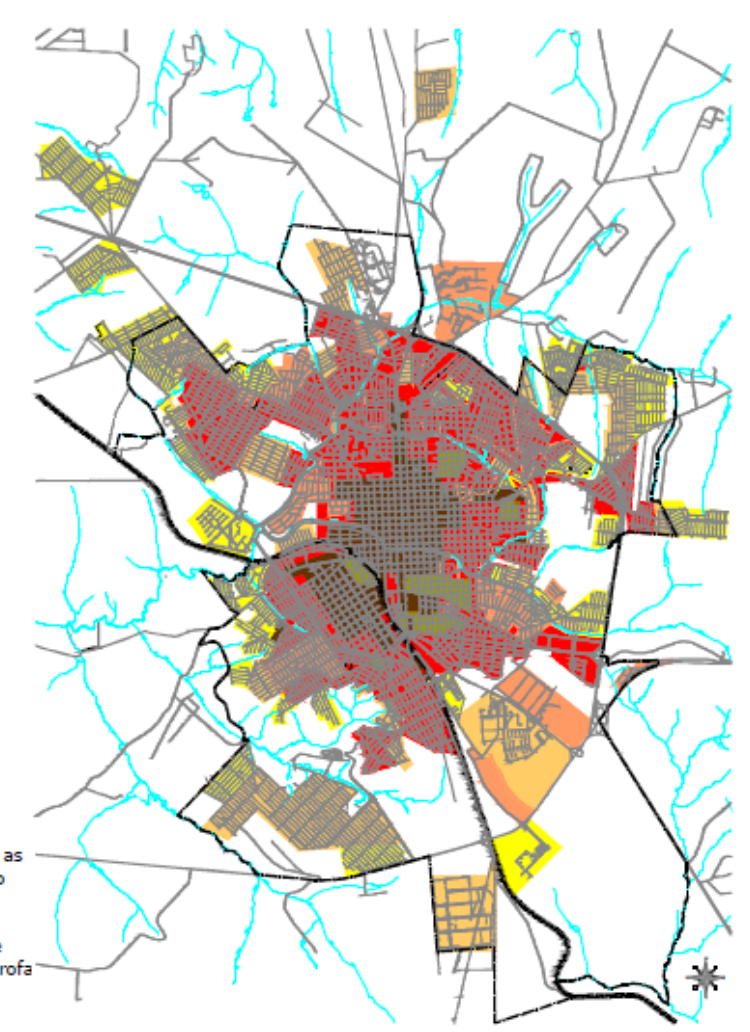

População:

1940 - 48.609 hab

$1970-85.425$ hab

2001 - 197.187 hab

\section{- $\cdot$ - - - - Limite da Área Urbana \\ m+m+m+m+m+m+m Ferrovia}

Fontes:

- Amador, Itamar Moraes, "As Manifestações Sociais e Econômicas Conjugadas com as Condições Fisico-Ambientais, determinam a Paisagem Urbana. Estudo de Caso - São Carlos - SP", 1990,

- Sisinotto, Dagmar Abadia, Evolução Urbana de São Carlos, São Carlos, 1988, Universidade de São Paulo - Escola de Engenharia de São Carlos - Departamento de Arquitetura e Planejamento, Trabalho de Iniciação Científica CNPq, orientado pela Profa Maria Ângela Bortolucci

Figura 13 - Desenvolvimento urbano de São Carlos (PMSC, 2003)

Em 30 anos, de 1970 até 2000, a população e a área de ocupação do território dobraram. Nos anos 1980 se pode destacar a consolidação das áreas de periferia, sendo que os vetores de expansão pressionam áreas que exigem muitos cuidados para ocupação, tais como mananciais de abastecimento e a Área de Proteção Ambiental de Corumbataí.

De acordo com Fabbro Neto (2004), a análise da densidade demográfica de São Carlos durante o período de 1991 a 2000 evidencia um processo de aumento de moradores na periferia, conforme Figura 14. A situação da expansão é configurada pela concentração da população de baixa renda na periferia Sul, afastada das áreas de infraestrutura consolidada, enquanto a região Norte-Noroeste abriga a população de maior renda, conforme a Figura 15.

De acordo com PMSC (2003), até 1991 cerca de 50 a 70\% da população com rendimentos de até 3 salários mínimos se encontrava distribuída pela cidade. Em 2000, é acentuado a separação entre ricos e pobres no território, agravando a segregação sócioespacial. As zonas de extrema riqueza e pobreza se tornam mais delimitadas e se perdeu parte da mistura social que havia na malha urbana (PMSC, 2003). 
1991

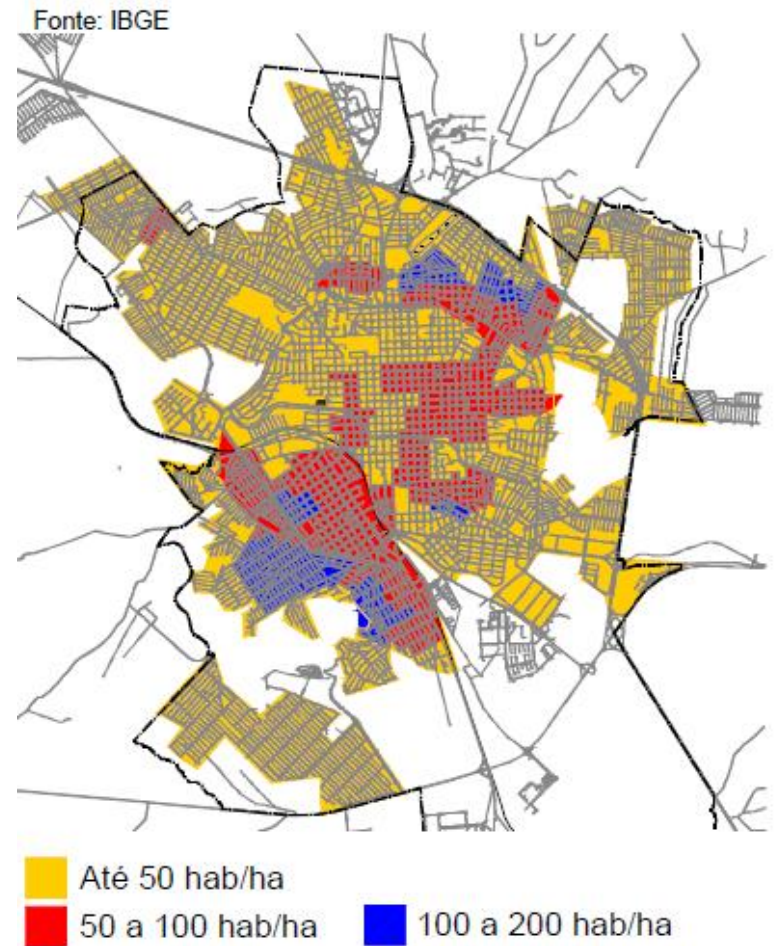

2000

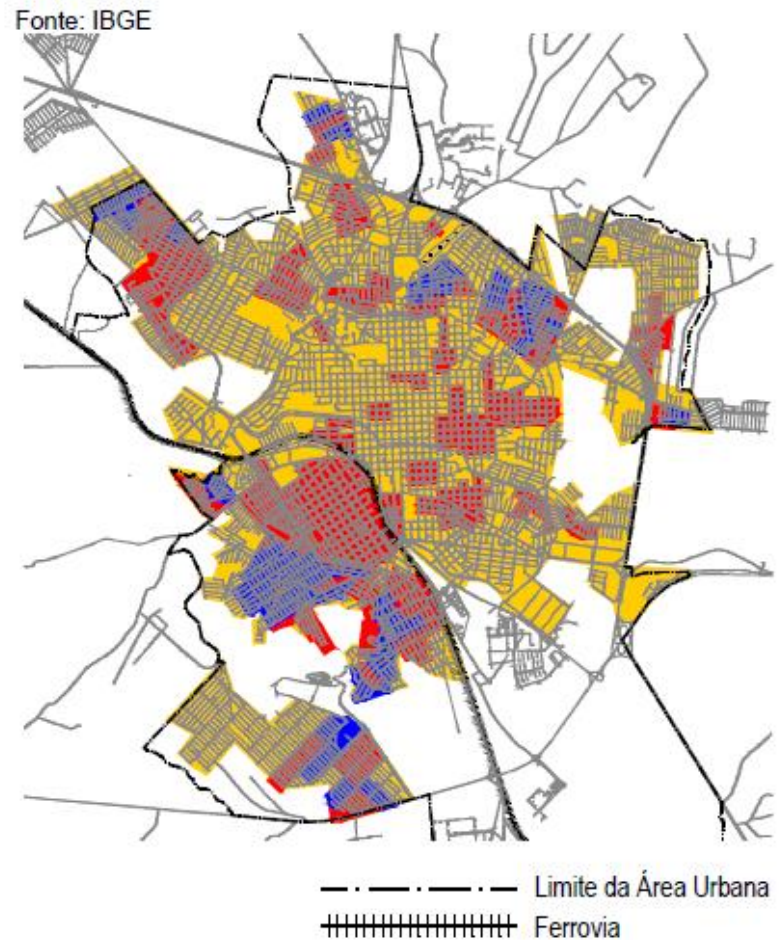

Figura 14 - Variação da densidade populacional (PMSC, 2003)

\section{1}

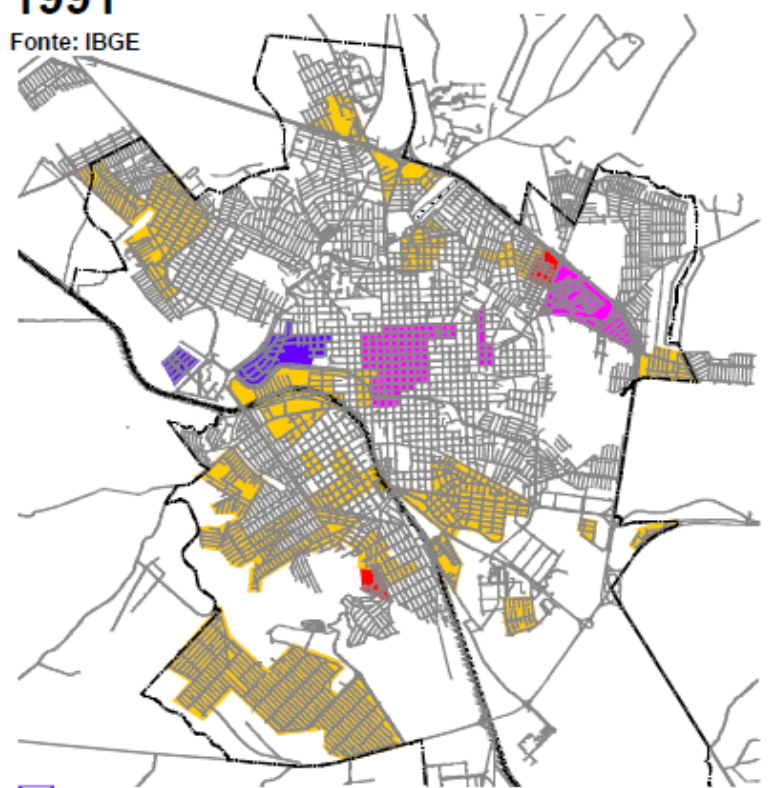

$70 \%$ Ou mais chefes com rendimento de mais de $10 \mathrm{SM}$ $30 \%$ A $70 \%$ Chefes com rendimento de mais de $10 \mathrm{SM}$ $50 \%$ A $70 \%$ Chefes com rendimento de até $3 \mathrm{SM}$ $70 \%$ Ou mais chefes com rendimento de até 3 SM

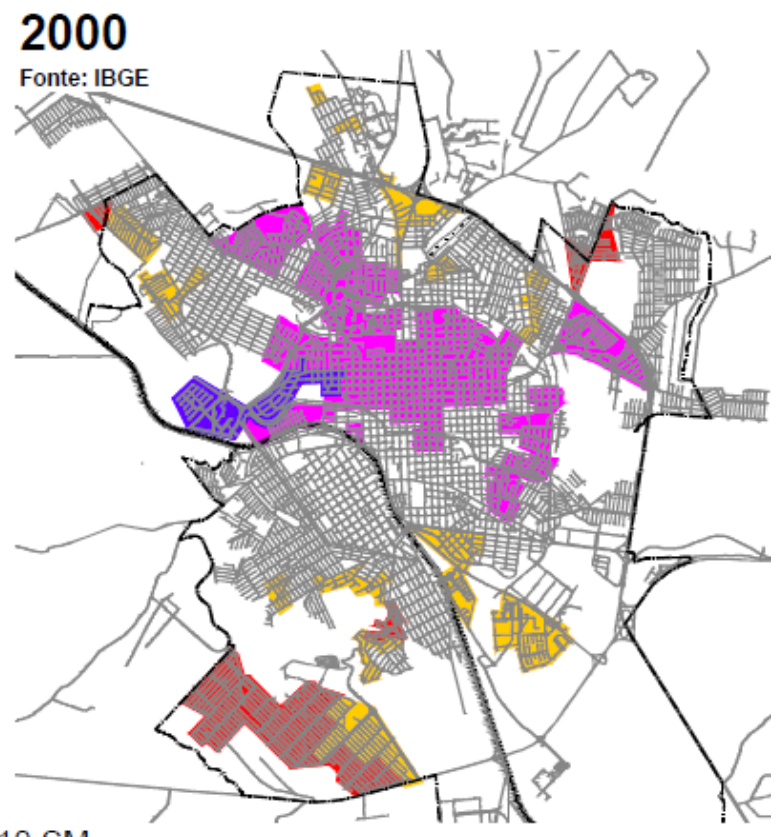

- $\cdot$ - - - - L Limite da Área Urbana

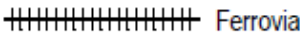

Figura 15 - Concentração de renda por chefes de família (PMSC, 2003) 
A lógica do uso e ocupação do solo municipal, segundo PMSC (2003), tem sido regulada pelo interesse imobiliário, não vinculado às condições de infraestrutura, gerando problemas de mobilidade, moradia e degradação ambiental. Excluindo-se as áreas de preservação ambiental e aquelas suscetíveis à erosão, 20\% do total da área urbana passível de ocupação estão desocupadas. A expansão da ocupação tem se dado em regiões cada vez mais distantes e ambientalmente frágeis, como na direção das microbacias do Monjolinho e do Feijão, ao Sul do Município (PMSC, 2003).

As condições de infraestrutura relativas aos sistemas de drenagem urbana, de esgotamento doméstico e de abastecimento de água são mais críticas nas áreas periféricas. Para PMSC (2003), a permissividade da legislação municipal de parcelamento do solo e a ausência de uma fiscalização técnica mais efetiva permitiram a ocorrência de obras de infraestrutura executadas de forma precária e incompleta.

De acordo com PMSC (2003), apesar do sistema de abastecimento de água atender toda a cidade, este não está interligado e possui reserva insuficiente, apresentando como consequência à existência de algumas áreas sujeitas a risco de interrupção no abastecimento, que é feito aproximadamente, 50\% por captação de águas superficiais no Córrego do Monjolinho e do Feijão, e 50\% de águas subterrâneas com poços profundos.

Em 2003, 100\% do esgoto da cidade era lançado sem tratamento no Córrego do Monjolinho, sendo que a Estação de Tratamento de Esgoto - ETE foi inaugurada em 2008. As condições de abastecimento de água e tratamento de esgoto influenciam na qualidade dos recursos hídricos das diferentes bacias hidrográficas. O município de São Carlos está inserido em duas grandes bacias hidrográficas: Mogi-Guaçu e Tietê-Jacaré. Segundo PMSC (2003), nesta última está localizada a maior parte da zona urbana. Estas duas bacias são subdivididas em dez microbacias, conforme Figura 16, sendo as de maior relevância:

- Microbacia do Monjolinho: a jusante recebe todo o esgoto da cidade na ETE e a montante oferece um importante ponto de captação para o abastecimento de água da cidade no manancial Espraiado.

- Microbacia do Feijão: situada na APA Corumbataí, é responsável por $40 \%$ do abastecimento de água de São Carlos. A Microbacia do Feijão é área de recarga do Aqüífero Guarani.

- Microbacia do Quilombo: nesta bacia é que se encontra um veio de comunicação histórico pelo qual se estabeleceram grandes propriedades do ciclo cafeeiro. Atualmente, o Vale do Quilombo é considerado o grande vetor de potencial turístico histórico-ecológico no município. 

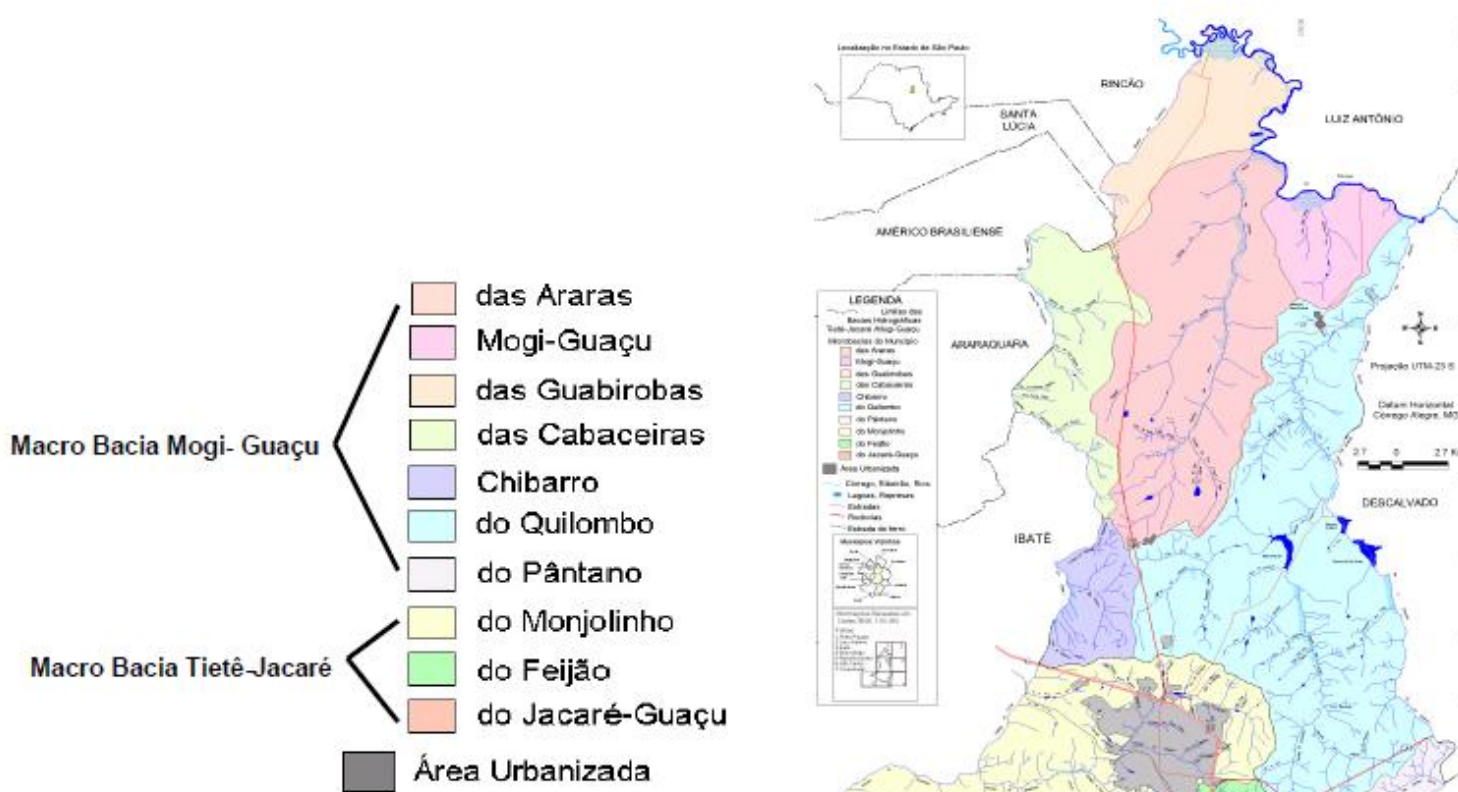

Fonte: SMDSCT
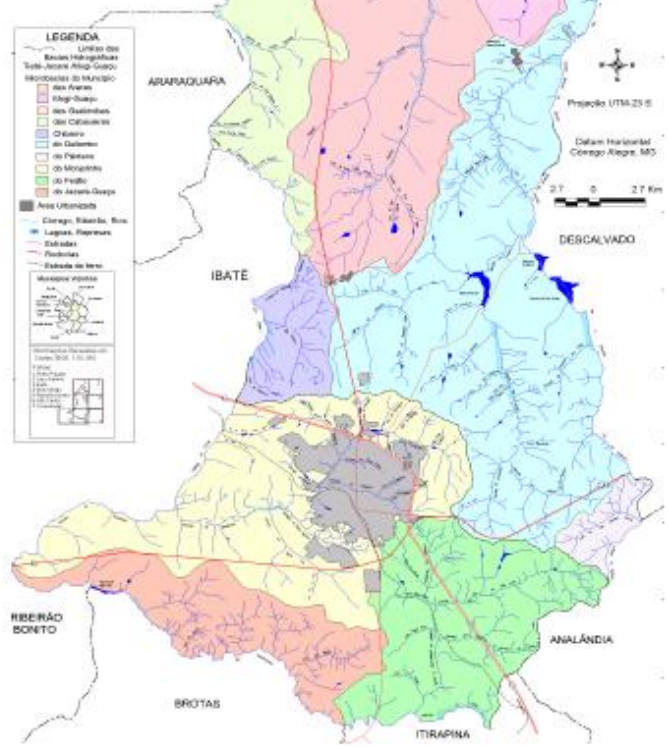

Figura 16 - Bacias Hidrográficas no território de São Carlos (PMSC, 2003)

As tendências de uso e ocupação do solo no município de São Carlos podem ser analisadas pela evolução dos mapas elaborados pela Prefeitura Municipal e apresentados na Conferência da Cidade em 2003. Pela análise destes se pode identificar que a região Sul está entre as mais recentes vertentes de expansão urbana, possuindo a maior densidade demográfica da cidade. A concentração de renda também é mais baixa nesta área, o que se reflete em suas piores condições de infraestrutura, como abastecimento de água, drenagem, ilustrados na Figura 17 e tipologias da edificação padrão, como ilustra a Figura 18. 
Drenagem . Erosão . Alagamento

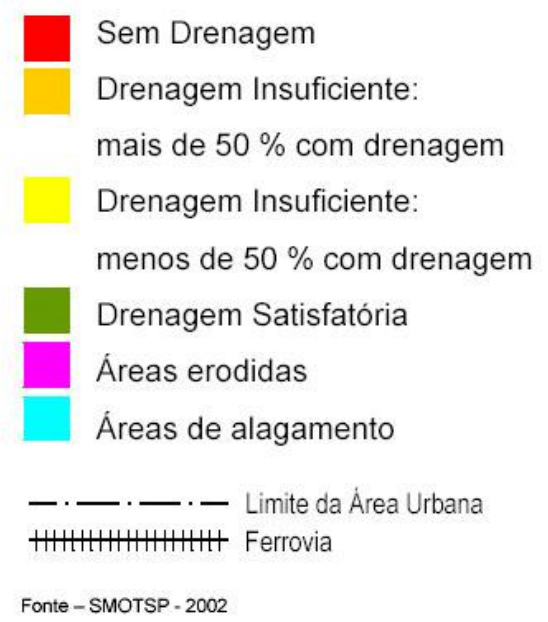

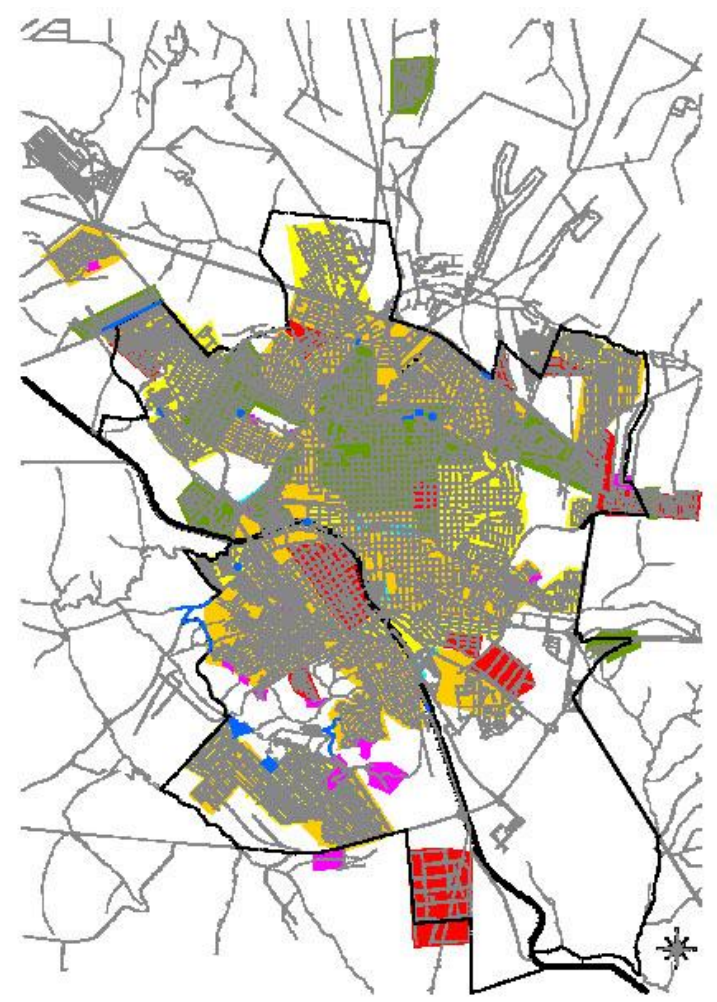

Figura 17 - Drenagem Urbana (PMSC, 2003)

Em contrapartida, a região com infraestrutura consolidada do município é dotada de patrimônio histórico em condições que permitem sua preservação. Esta sofre decréscimo populacional, sendo que o uso se concentra em comércio e serviços, com verticalização concentrada no eixo da avenida estruturadora do trânsito municipal, a Avenida São Carlos. Simultaneamente, é identificada a presença de lotes subutilizados e construções desocupadas, com a presença significativa de áreas públicas e equipamentos coletivos (FABBRO NETO, 2004). 


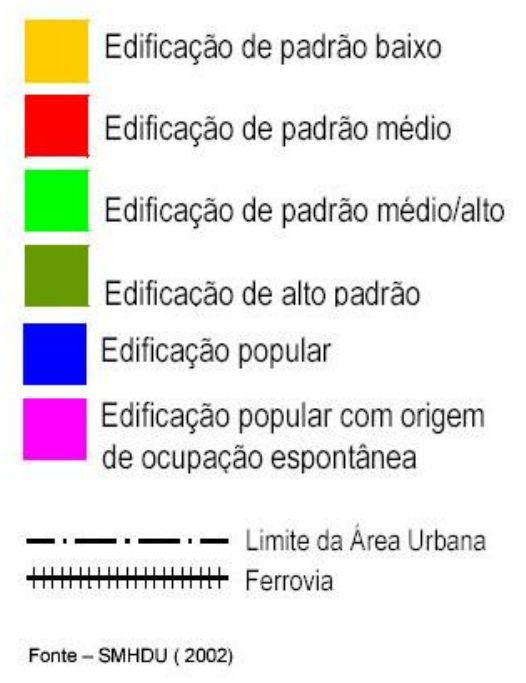

Figura 18 - Edificação Padrão (PMSC, 2003)

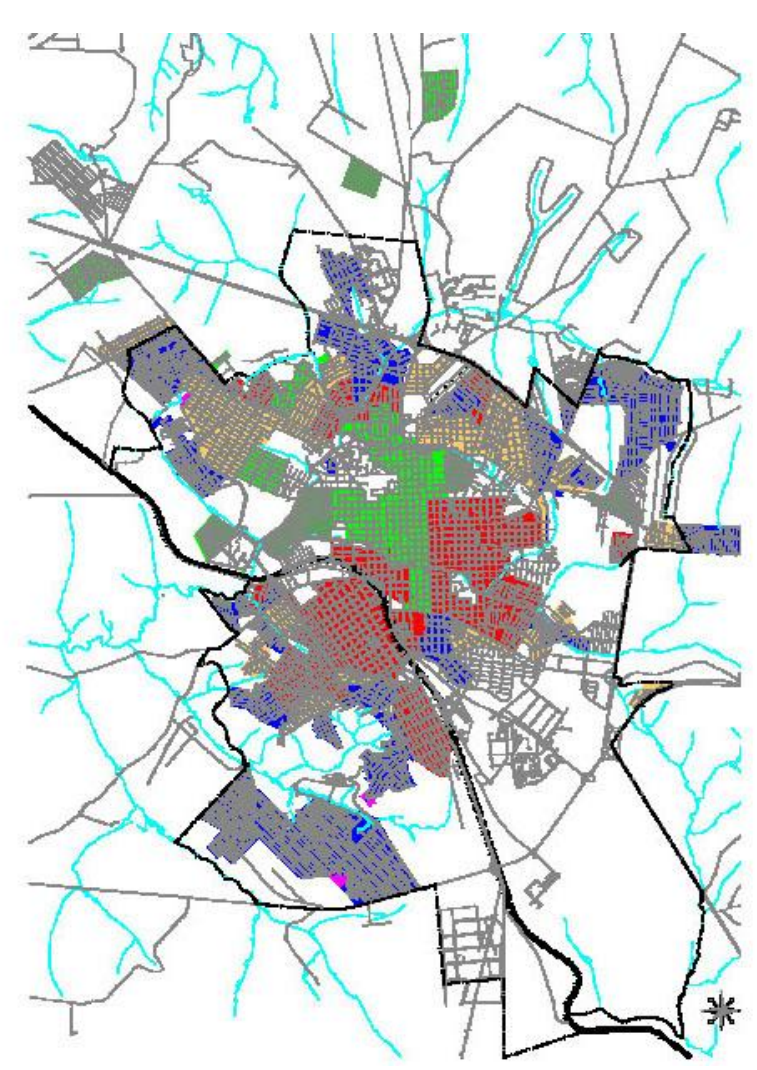

As diferentes características e problemáticas identificadas pela análise do desenvolvimento histórico e da situação atual do município de São Carlos podem servir de base para as indicações do Plano Diretor Municipal e do Zoneamento Urbano, de modo que sejam corrigidos e controlados os problemas provocados pelo uso e ocupação do solo durante o sistema de regulação anterior a sua formulação.

\subsection{PLANO DIRETOR MUNICIPAL DE SÃO CARLOS}

O instrumento de gestão aplicado ao planejamento do uso e ocupação do solo no município de São Carlos, em atendimento ao Estatuto da Cidade, é o Plano Diretor Municipal. O processo de elaboração do conteúdo do plano, a forma de sistematização das informações e o conteúdo final são apresentados pela sua importância para o entendimento das relações entre as decisões tomadas e a influência exercida pela participação dos atores interessados.

Com o intuito de adequar-se ao Estatuto da Cidade, a PMSC iniciou em 2001 o processo de Elaboração do Plano Diretor Municipal de São Carlos - PDMSC - com a realização de plenárias públicas para o debate e a divulgação da evolução dos trabalhos, 
iniciadas com o seminário de um dia (27/10/2001) no Teatro Municipal, para a discussão do impacto do Estatuto da Cidade no planejamento municipal, na legislação e na política habitacional, incluindo palestras sobre a política fundiária, a gestão de programas, os projetos habitacionais e a gestão democrática. Ainda em 2001 foi realizado o Fórum da Cidade em dois dias (08 e 09/11/2001), no auditório do Colégio Diocesano La Salle, com a apresentação do diagnóstico de todos os setores da administração pública municipal sob a ótica da gestão, do desenvolvimento urbano e do planejamento físico e territorial por representantes de secretarias, autarquias e fundações do município de São Carlos.

No ano de 2002 foi dada a continuidade às discussões com a Conferência da Cidade, realizada num único dia (24/08/2002), dez meses após a primeira plenária para a deliberação sobre a constituição do Comitê Consultivo como uma instância de representatividade da sociedade local, para discussões temáticas visando aprofundamento do diagnóstico e das propostas do PDMSC. A composição do referido Comitê envolveu a participação popular, de especialistas na área e de gestores da administração pública, como representantes de organizações da sociedade civil, associações de entidades de classe, entidades assistenciais e religiosas, associações de bairros, sindicatos, imprensa, Universidades públicas, faculdades e escolas particulares, comissões de orçamento participativo, órgãos e serviços estaduais e federais, conselhos municipais, todos os vereadores da câmara municipal e membros das secretarias, autarquias e fundações municipais.

Foi realizado ainda um workshop de desenvolvimento rural (07/11/2002) no auditório da Empresa Brasileira de Pesquisa Agropecuária - EMBRAPA, com a formação de grupos de trabalhos temáticos sobre zoneamento agroambiental, a vocação regional rural e agricultura familiar com segurança alimentar. No ano de 2003 houve a Conferência da Cidade (09/08/2003) para o compartilhamento e discussão da proposta do PDMSC com participação de representantes da sociedade civil, do Comitê Consultivo, professores, estudantes, população em geral e membros do governo. Neste evento foram extraídos os elementos básicos para a elaboração do Projeto de Lei que foi encaminhado em novembro de 2003 à Câmara Municipal.

Antes da Conferência da Cidade, houve seis reuniões para a apresentação e discussão do diagnóstico, sendo uma reunião geral com o comitê consultivo (14/09/2002), uma reunião (09/10/2002) sobre legislação, duas reuniões (30/10/2002 e 13/11/2002) sobre saneamento, preservação e recuperação ambiental na cidade e no município, e duas reuniões (04/12/2002 e 18/12/2002) sobre a territorialização das atividades econômicas. Para a apresentação e discussão da proposta houve cinco reuniões, sendo uma (29/04/2003) sobre 
macrozoneamento, zoneamento urbano, adensamento e vetores de expansão, outra (22/05/2003) sobre zoneamento urbano e áreas de especial interesse em meio urbano, outra (12/06/2003) sobre zoneamento da macrozona de uso multifuncional rural, uma (02/07/2003) sobre coeficientes urbanísticos e os instrumentos do Estatuto da Cidade, e uma última reunião (16/07/2003) sobre perímetro urbano e instrumentos do Estatuto da Cidade aplicados em São Carlos, totalizando 11 reuniões entre os anos de 2002 e 2003. Dentro da comissão executiva foram selecionados os membros para a composição do grupo de trabalho técnico e operacional, que contou com a assessoria técnica do Instituto Pólis e do Departamento de Arquitetura da Escola de Engenharia de São Carlos da Universidade de São Paulo.

Além dos eventos e das reuniões já relacionadas com o Comitê Consultivo, foram realizadas reuniões com os diferentes segmentos da sociedade para o esclarecimento e discussões das propostas do PDMSC, dentre eles os representantes da Associação Comercial e Industrial de São Carlos, Conselho Regional dos Corretores Imobiliários e com a Associação dos Engenheiros, Arquitetos e Agrônomos do município.

No ano de 2004, a Comissão de Urbanização, Transportes e Habitação da Câmara Municipal de São Carlos organizou três audiências públicas para apresentação e debate do Projeto de Lei do PDMSC, sendo a primeira sobre o diagnóstico da cidade (12/05/2004), a segunda sobre o zoneamento, coeficientes e áreas de especial interesse (24/06/2004) e a terceira sobre os instrumentos de política urbana e a gestão do PDMSC (19/08/2004).

Já no ano de 2005 a Presidência da Câmara dos Vereadores estabeleceu um cronograma de trabalho contemplando uma série de atividades relativas ao processo de discussão, de apresentação de emendas e de votação. Este cronograma teve início com a realização de mais quatro audiências públicas, com o intuito de aprofundar o debate sobre diferentes aspectos do PDMSC, sendo que a quarta audiência foi promovida pela Comissão de Legislação, Justiça e Redação sobre legislação urbana, a quinta foi promovida pela Comissão de Economia, Finanças e Orçamento sobre planejamento urbano, a sexta foi promovida pela Comissão de Saúde, Meio Ambiente e Promoção Social sobre o meio ambiente e a sétima e última audiência foi promovida pela Comissão de Urbanização, Transporte e Habitação sobre o PDMSC propriamente dito.

Todas as reuniões, debates e conferências realizadas para subsidiar as discussões do conteúdo a ser abrangido pelo PDM foram realizados na região central do município ou no seu entorno imediato. O Plano Diretor é composto por uma série de recursos e instrumentos de política urbana que são empregados para que se possa viabilizar a implementação de diretrizes gerais, princípios e objetivos estabelecidos para o ordenamento físico e territorial do 
município. Os principais componentes do PDMSC, que foram transformados em Lei Municipal 13.691 de 2005, são:

- Macrozoneamento do Município, criando a macrozona urbana e a macrozona de uso multifuncional rural, conforme a Figura 19;

- Zoneamento das macrozonas urbanas e rural, conforme a Figura 20:

1.ZONA DE OCUPAÇÃO INDUZIDA - Z1:

Possui as melhores condições de infraestrutura da cidade, com a predominância do uso misto em detrimento do uso habitacional e a presença de imóveis históricos.

Apresenta população com perfil de alta renda e de população idosa e está localizada entre a Ferrovia e a Rodovia Washington Luiz - SP310.

2.ZONA DE OCUPAÇÃO CONDICIONADA - Z2:

Possui diversidade de padrão construtivo com a predominância do uso misto. É caracterizada pela fragmentação do sistema viário, com carência de drenagem e deficiência em áreas públicas e equipamentos. Apresenta também assentamentos irregulares.

3.ZONA DE RECUPERAÇÃO E OCUPAÇÃO CONTROLADA - Z3A e Z3B:

Z3A:

É caracterizada pela fragilidade social e ambiental, possuindo alta declividade, solo erosível e córregos assoreados. Apresenta infraestutura precária, com loteamentos irregulares próximo de encostas e população de baixa renda

Z3B:

É considerada área de proteção e recuperação do manancial Monjolinho, possui carência de drenagem e equipamentos comunitários. Possui difícil acesso em função da barreira da Rodovia SP-310. 
4. MACROZONA MULTIFUNCIONAL RURAL - Z4A e ZAB:

Z4A:

É caracterizada pela presença de condomínios fechados, chácaras de recreio, campo de golfe e áreas com habitação, comércio e lazer, incluindo o distrito de Água Vermelha. É destacada a presença do Aterro Sanitário municipal e a necessidade de elaboração do Plano de Saneamento.

Z4B:

É caracterizada pela presença de áreas contíguas ou circundada por setores urbanizados, com potencial de expansão urbana. A referida zona é seccionada pela SP-310.

5.ZONA DE PROTEÇÃO E OCUPAÇÃO RESTRITA - Z5:

Destinada a promoção da recuperação da qualidade das águas superficiais, nesta zona se encontra a Área de Proteção Ambiental APA, com nascentes e mananciais de abastecimento. Possui o campus da Universidade Federal de São Carlos - UFSCar.

6. ZONA DE PRODUÇÃO AGRÍCOLA FAMILIAR - Z6:

É caracterizada pela maior altitude do território, possuindo nascentes e parcelamentos irregulares;

7.ZONA DE USO PREDOMINANTEMENTE AGRÍCOLA - Z7:

Possui grande diversidade de agrossistemas, com potencial de lazer e turismo, apresentando abundância de recursos hídricos. Nesta zona está localizado o distrito de Santa Eudóxia. 


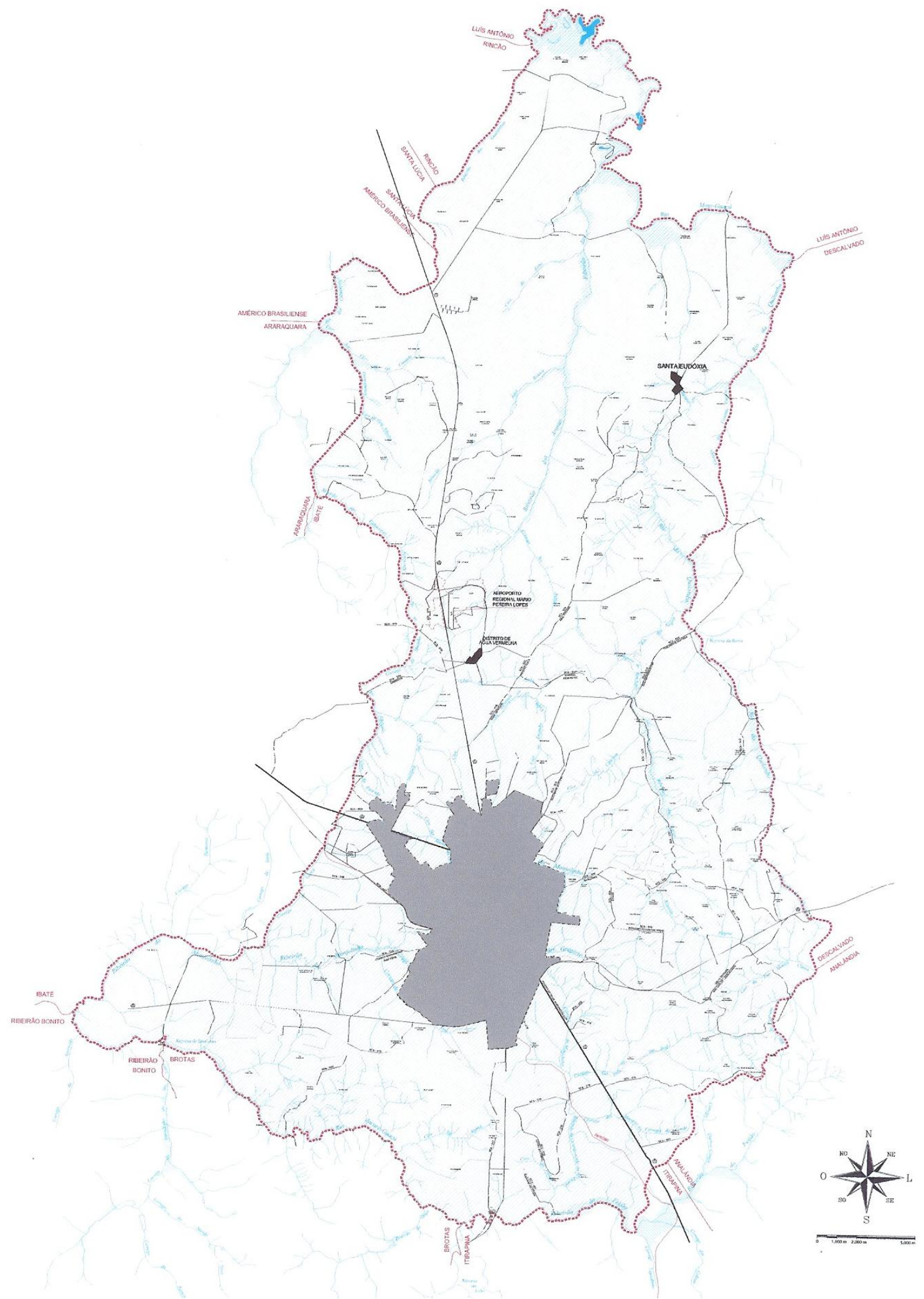

Figura 19 - Macrozona Urbana (área escura) e Macrozona Rural (área clara) (PMSC, 2005) 


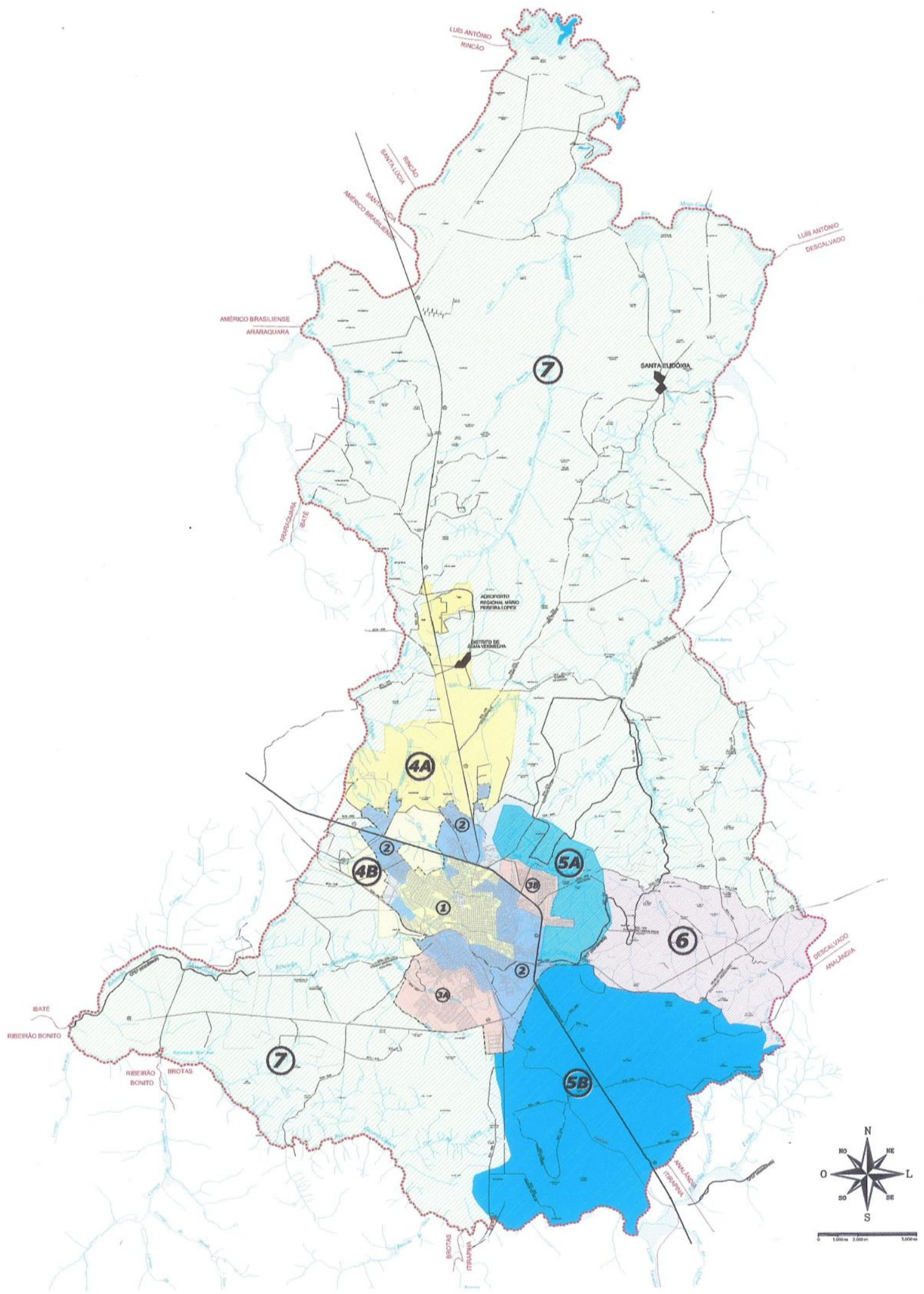

Figura 20 - Zoneamento das macrozonas urbana e rural (PMSC, 2005) 
- Áreas de Especial Interesse, onde as singularidades das áreas podem ocorrer em diferentes aspectos, sendo que a conformação de Áreas de Especial Interesse Ambiental é importante para destacar os atributos que se queira proteger, preservar, conservar, requalificar ou recuperar (SILVA e TEIXEIRA 2009):

\section{1. ÁREAS ESPECIAIS DE INTERESSE HISTÓRICO:}

É caracterizada pelo chamado polígono histórico na Z1 e Z2, apresentando imóveis tombados em meio rural. É destinada para desenvolver atividades educacional, cultural e turística.

2. ÁREAS ESPECIAIS DE INTERESSE AMBIENTAL:

São os córregos, o Aterro Sanitário e antigos lixões, o Parque Florestal Urbano, as imediações da Estação Ecológica em um raio de $500 \mathrm{~m}$ e também a estrada do eixo complementar para Ribeirão Bonito - SP-210 localizada em área rural.

3. ÁREAS ESPECIAIS DE INTERESSE TURÍSTICO, HISTÓRICO E ECOLÓGICO:

São os distritos de Santa Eudóxia, Água Vermelha e a Represa do Lobo - Broa.

4. ÁREAS ESPECIAIS DE INTERESSE TURÍSTICO, ESPORTIVO E ECOLÓGICO:

Área do campo de golfe na Fazenda do Urso.

5. ÁREAS ESPECIAIS DE INTERESSE INDUSTRIAL:

São: o Centro Empresarial de Alta Tecnologia - CEAT Dr. Emílio Fehr, o Distrito Industrial Miguel Abdelnur, a Fábrica de Motores da Volkswagen e o São Carlos Science Park.

6. ÁREAS ESPECIAIS DE INTERESSE DO TRANSPORTE AÉREO:

São as imediações do Aeroporto Mário Pereira Lopes.

7. ÁREAS ESPECIAIS DE INTERESSE SOCIAL:

São porções do território destinadas a proporcionar condições de moradia à população de baixa renda, na Z1, Z2 e Z3A.

- Diretrizes viárias, traçando diretrizes para a implantação de dispositivos de acesso e transposição da SP-310, implantação de vias arteriais e afastamentos; 
- Parcelamento, Uso e Ocupação do Solo:

1. PARCELAMENTO que poderá ser empreendido por meio de loteamento, desmembramento, desdobro ou remembramento, considerando o tamanho do lote e o percentual entre áreas públicas e privadas e estabelecendo diretrizes gerais para fins urbanos, chácaras de recreio, urbanização específica no caso de regularização fundiária, condomínios habitacionais e empreendimentos habitacionais de interesse social;

2. USO DO SOLO, sendo que, segundo o artigo 140 do PDMSC, em todo o território do Município de São Carlos será permitido o uso misto, desde que atendidas às restrições às atividades geradoras de impactos e incômodos, expressas em cada Zona definida, e excluindo-se aqueles já consolidados, nos quais o uso pré-estabelecido como estritamente residenciais ou estritamente industriais que não tenha sido alterado. Relativo a usos e atividades incômodas, é estabelecido parâmetros para poluição sonora, atmosférica, hídrica e de geração de resíduos;

3. OCUPAÇÃO DO SOLO, onde são estabelecidos coeficientes de aproveitamento considerando a relação entre a área do lote e a área construída, coeficientes de permeabilidade e de cobertura vegetal.

- Instrumentos de indução da Política Urbana:

1. UTILIZAÇÃO, EDIFICAÇÃO E PARCELAMENTO COMPULSÓRIOS, que são destinados ao controle da ociosidade urbana para que haja um melhor aproveitamento da infraestrutura instalada e uma limitação à prática da especulação imobiliária. Sua aplicação ocorre por meio da obrigatoriedade de parcelar, edificar ou utilizar propriedades ociosas que não estejam cumprindo sua função social. Segundo Silva \& Teixeira (2009), como a função ambiental pode ser compreendida como parte da função social, as propriedades relevantes sob o ponto de vista ambiental, seja pela capacidade de manutenção da permeabilidade do solo ou pela qualidade de sua cobertura 
vegetal, não seriam consideradas ociosas mesmo não sendo parceladas, edificadas ou utilizadas.

2. DIREITO DE PREEMPÇÃO que confere ao Poder Público Municipal a preferência para a aquisição de imóvel urbano, delimitado em Lei específica nas áreas situadas na Z1, Z2 e $\mathrm{Z} 3 \mathrm{~A}$;

3. DIREITO DE SUPERFÍCIE que abrange o direito de utilizar o solo, o subsolo ou o espaço aéreo relativo ao terreno por tempo determinado ou indeterminado, mediante escritura pública registrada no Cartório de Registro de Imóveis;

4. OUTORGA ONEROSA DO DIREITO DE CONSTRUIR, entendido como a separação entre o direito de propriedade e o direito de construir, segundo a perspectiva de cumprimento do princípio da função social da propriedade;

5. OUTORGA ONEROSA DE ALTERAÇÃO DE USO DO SOLO, podendo ser aplicado no controle da passagem do uso do solo rural para o urbano, controlando a expansão horizontal das cidades e a especulação imobiliária. Segundo Silva e Teixeira (2009), sob o ponto de vista ambiental é significativa esta possibilidade de um instrumento que possa controlar o parcelamento do solo para fins urbanos em zonas rurais.

6. OPERAÇÕES URBANAS CONSORCIADAS, que permitem a modificação de coeficientes e características de parcelamento, uso e ocupação do solo e subsolo, bem como a alteração das normas edílicas e a regularização de construções, reformas ou ampliações executadas em desacordo com a legislação vigente, aplicáveis na Z1 e Z2. Segundo Silva e Teixeira (2009), é composto por um conjunto de intervenções integradas que envolvem moradores, usuários, empreendedores e proprietários, sob a coordenação do Poder Público Municipal. Segundo o Estatuto da Cidade, Parágrafo $1^{\circ}$ do Art. 32, tem o objetivo de qualificar social, ambiental e urbanisticamente determinados setores da cidade; 
7. TRANSFERÊNCIA DO DIREITO DE CONSTRUIR, cuja função básica é autorizar proprietários de determinados imóveis a exercerem na Z1 e Z2 o potencial construtivo não usufruído em uma determinada propriedade quando o referido imóvel for considerado necessário para fins de implantação de equipamentos urbanos e comunitários, preservação histórica e regularização fundiária;

8. ESTUDO DE IMPACTO DE VIZINHANÇA para os empreendimentos que tenham significativa repercussão no meio ambiente ou sobre a infraestrutura. Cabe observar que, segundo Oliveira (2004), o Estudo de Impacto de Vizinhança não é um instrumento adequado para avaliar os impactos de um determinado empreendimento no meio ambiente. Este instrumento é o Estudo de Impacto Ambiental, que por sinal está presente na lista de instrumentos a serem utilizados no Plano Diretor Municipal.

- Sistema de Gestão e Planejamento do Desenvolvimento Urbano:

Compreende organismos de gestão para compatibilizar políticas, planos e programas, como a Conferência da Cidade, o Conselho Municipal de Desenvolvimento Urbano, o Grupo Especial de Análise formado por servidores públicos qualificados tecnicamente e ainda o Fundo Municipal de Habitação e Desenvolvimento, destinado a propiciar apoio e suporte financeiro à consecução da política municipal de desenvolvimento urbano e habitação de interesse social, organizando a captação, o repasse e a aplicação de recursos.

Cabe ressaltar que, segundo o art. 240 do PDMSC, a regulamentação, a gestão e a complementação do PDMSC serão feitas por meio de um arcabouço normativo composto de Leis e Decretos Municipais, sendo que os únicos planos previstos no PDMSC são o Plano Municipal de Mobilidade Sustentável (inciso VII) e o Plano de Macrodrenagem Urbana (inciso IX). 
Segundo o art. 242 o Município fica autorizado a firmar convênios com os municípios da região para solucionar problemas relativos aos resíduos sólidos, e segundo o Art. 243, fica também autorizado a promover consórcio intermunicipal com os municípios de Itirapina e Brotas visando garantir a manutenção das características ambientais da Microbacia Hidrográfica do Ribeirão do Feijão.

Em dezembro de 2009 foi realizada a $4^{\text {a }}$ Conferência Municipal da Cidade, sob coordenação da Secretaria Municipal de Habitação e Desenvolvimento Urbano, tendo como objetivo propiciar a participação popular da sociedade para a formulação de propostas relacionadas à Política de Desenvolvimento Urbano. Esta atividade marcou o início do processo de revisão do PDMSC, previsto para ocorrer ao longo do ano de 2010, como uma oportunidade para o aprimoramento dos instrumentos de gestão do território, a fim de levantar coletivamente sugestões, propostas e demandas para a primeira revisão do PDMSC. As discussões se concentraram em quatro eixos temáticos:

1. Criação e implementação de conselhos das cidades, planos, fundos e de seus conselhos gestores nos níveis federal, estadual e municipal, por serem entendidos como a garantia institucional do controle da implementação do Sistema Nacional de Desenvolvimento Urbano e das políticas estaduais e municipais correspondentes (PMSC, 2009);

2. Aplicação do Estatuto da Cidade e dos Planos Diretores e a efetivação da função social da propriedade do solo urbano, já que os instrumentos e conceitos de política urbana concebidos pelo Estatuto não foram amplamente absorvidos e aplicados, apontando para a necessidade do seu aprimoramento (PMSC, 2009);

3. Integração da política urbana no território, envolvendo a política fundiária, de habitação, de saneamento, de mobilidade e acessibilidade urbana, procurando envolver todas as esferas de governo, buscando a integração de ações pontuais mesmo que não sejam executadas no mesmo período de tempo (PMSC, 2009);

4. Relação entre os programas governamentais e a política de desenvolvimento urbano, uma vez que alguns dos programas federais estimulam o crescimento da economia e, ao mesmo tempo, representam uma grande ampliação dos investimentos em habitação, 
saneamento e mobilidade urbana, com base nas políticas setoriais definidas pelo Conselho das Cidades e pelo Ministério das Cidades (PMSC, 2009).

Entre as contribuições mais significativas do Plano Diretor de São Carlos estão à realização do zoneamento municipal e a criação de instrumentos para gerenciar o uso e a ocupação do solo. No entanto, quando é considerado o diagnóstico das características urbanas apresentadas na $1^{\mathrm{a}}$. Conferência da Cidade se identifica que as diferenças do uso e ocupação do solo não foram internalizadas de maneira detalhada no zoneamento municipal. Entre as considerações mais notáveis também está à falta de detalhamento da porção rural do território e seus respectivos recursos naturais, como a presença de fragmentos florestais ou percentuais de áreas de reserva legal demarcados. A falta do detalhamento dos recursos naturais presentes na área rural e a homogeneização das características urbanas presentes no zoneamento municipal não compõem os eixos temáticos selecionados para o processo de revisão do Plano Diretor Municipal, iniciado pela $4^{\mathrm{a}}$. Conferência da Cidade, o que indica uma oportunidade de melhoria para o processo de revisão do planejamento de uso do solo de São Carlos. 


\section{AAE, A TOMADA DE DECISÃO E O ESTATUTO DA CIDADE.}

Alshuwaikhat (2004) menciona que as experiências práticas sugerem que o EIA é insuficiente para garantir a qualidade ambiental e promover o desenvolvimento sustentável do uso e ocupação do solo. Por sua vez, João (2007) relata que a AAE considera um escopo maior de impactos e usa a avaliação em cascata para outros níveis de ação. Desta maneira, o EIA pode incorporar as orientações da AAE ou analisá-las de maneira mais aprofundada. Como AAE ocorre antes das decisões no nível do projeto, os órgãos técnicos podem considerar as alternativas no nível político e os programas de medidas mitigadoras (SHEPERD \& ORTOLANO, 1996).

Um dos benefícios da avaliação realizada pela AAE anterior à avaliação realizada pelo EIA é levar os princípios do suporte da sustentabilidade das políticas, planos e programas PPPs - para os projetos. Outro benefício está na eficiência, já que as ligações podem direcionar os EIAs quando os projetos propostos são consistentes com os valores existentes na AAE. Os EIAs podem tanto fazer referências como reavaliar as análises da AAE (SÁNCHEZ \& SILVA-SÁNCHEZ, 2008).

Partidário (2002) menciona que os objetivos da AAE estão no exame sistemático dos possíveis impactos ambientais das PPPs, a fim de evitar os efeitos negativos e, na impossibilidade, minimizar os impactos adversos. AAE pode recomendar medidas mitigadoras que são mais rapidamente atingidas do que aquelas para projetos específicos, permitindo a consideração sistemática e participativa dos princípios da sustentabilidade no processo de planejamento. Também, segundo João (2007), a AAE propicia uma maneira de considerar impactos cumulativos, além de ajudar a identificar, gerenciar e monitorar estes impactos sobre grandes áreas e longos períodos de tempo.

O monitoramento das diversas etapas e da implementação da proposta escolhida pode ser um elo essencial entre a implementação das metas dos projetos de curto prazo e as metas de desenvolvimento sustentável em longo prazo. O monitoramento pode ser utilizado para determinar quando as medidas mitigadoras vêm sendo implantadas e quando são efetivas. Isso pode identificar impactos não previstos, ou se os impactos se aproximam de um nível crítico, refinando as previsões realizadas. A existência de medidas mitigadoras pode ser adaptada, ou fazer com que novas medidas mitigadoras sejam implementadas antes que seja tarde demais para prevenir ou reduzir impactos inaceitáveis. Além do mais, os reais efeitos da implantação das PPPs podem ser comparados com os efeitos pré-determinados da capacidade previsões de impacto (THERIVEL, 2004). 
O envolvimento da sociedade propicia contribuições para a sustentabilidade na medida em que considera diferentes percepções ambientais sobre as interações do meio com a ação proposta. O problema com a participação no EIA ocorre porque ela surge muito tarde para influenciar as decisões-chave, durante as audiências públicas (SHEPHERD E ORTOLANO, 1996). A participação da sociedade na AAE pode ocorrer em tempo suficiente para influenciar decisões que possuem implicações em longo prazo, como no caso do planejamento municipal participativo. O envolvimento popular nas PPPs pode incorporar a percepção ambiental da comunidade de modo mais efetivo do que aqueles que ocorrem nos projetos individuais.

Alguns dos requerimentos dos produtos da Diretiva Européia 2001/42?EC colocam que determinados procedimentos devem ser seguidos, como os estudos das bases de referência, métodos de identificação de impactos e o desenvolvimento de procedimentos de monitoramento (CARTER \& HOWE, 2005).

Entre os procedimentos exigidos pela Diretiva Européia de AAE está a produção de um cronograma e um programa de trabalho, os quais também são exigidos pelo Estatuto da Cidade, proporcionando uma oportunidade de alinhar os procedimentos da AAE para a produção do PDMSC. O programa de trabalho, preparado ao encontro dos requerimentos da Diretiva Européia da AAE, pode identificar as etapas chaves do desenvolvimento do PDMSC, aos quais estes procedimentos de gestão devam ser integrados.

Alguns procedimentos considerados em termos de AAE para PDMSC propiciam uma possibilidade de como certos procedimentos do Estatuto da Cidade e da Diretiva Européia de AAE possam ser desenvolvidos em consonância, estão ilustrados na Figura 21.

A Figura 21 pode ser considerada um desdobramento da Figura 2, apresentada no Capítulo 4.1 do presente trabalho, no entanto, se refere quanto à decisão estratégica em questão sobre o ordenamento territorial dos municípios brasileiros, regulamentado pelo Estatuto da Cidade. Neste caso, as questões generalizadas acerca da tomada de decisão foram materializadas pelos procedimentos estipulados pelo Estatuto da Cidade. É interessante notar como a AAE permite que a variável ambiental seja incorporada durante as primeiras etapas estipuladas pelo Estatuto da Cidade, e que mais ao final do processo, algumas etapas de AAE já estão contempladas na estrutura regulamentada do Estatuto da Cidade.

As setas utilizadas ilustram como que a estrutura da AAE pode gradualmente contribuir para a incorporação das variáveis ambientais durante a aplicação do Estatuto da Cidade, e de como as decisões tomadas a partir do Estatuto da Cidade podem contribuir para a 
continuidade da realização da $\mathrm{AAE}$, configurando um processo de alimentação mútua entre os diferentes instrumentos.

Tomada de decisão estratégica / ESTATUTO DACIDADE

\begin{tabular}{|c|}
\hline $\begin{array}{c}\text { Identificar objetivos da ação estratégica: } \\
\text { ORDENAR O CONTROLE DO USO DO SOLO, } \\
\text { CONTEMPLADO DE FORMA ESPECÍFICA NO ART. } 2^{\circ} \text {., INCISO }\end{array}$ \\
\hline $\begin{array}{l}\text { Definir objetivos da ação e encontrar formas alternativas de alcançar a } \\
\text { resolução dos problemas: } \\
\text { CUMPRIR A FUNÇÃO SOCIAL DA PROPRIEDADE, ASSEGURAR } \\
\text { A JUSTIÇA SOCIAL E O DESENVOLVIMENTO DAS ATIVIDADES } \\
\text { ECONÔMICAS, CONTEMPLADO PELO ART. 39 }{ }^{\circ} \text {. } \\
\text { UTILIZAR OS PLANOS NACIONAIS, REGIONAIS E ESTADUAIS } \\
\text { DE ORDENAÇÃO DO TERRITÓRIO E DE DESENVOLVIMENTO } \\
\text { ECONÔMICO E SOCIAL. } \\
\text { UTILIZAR OS PLANOS, PROGRAMAS E PROJETOS SETORIAIS, } \\
\text { SEGUNDO O ART. } 4^{\circ} \text {. } \\
\text { (p. eX. PLANO DE BACIA HIDROGRÁFICA) }\end{array}$ \\
\hline
\end{tabular}

Escolha da melhor alternativa e detalhamento das instruções: UTILIZAR OS INSTRUMENTOS DE PLANEJAMENTO NACIONAI, REGIONAL E MUNICIPAL, ENTRE ELES O PLANO DIRETOR MUNICIPAL, CONFORME O ART. $4^{\circ}$

Refinar a alternativa escolhida e instruções:

DELIMITAR AS ÁREAS ONDE SERÃO APLICADOS OS INSTRUMENTOS DE INDUÇÃO DA POLÍTICA URBANA (ART. 42 ${ }^{\circ}$.), COMO O PARCELAMENTO, A EDIFICAÇÃO OU UTILIZAÇÃO COMPULSÓRIA DO SOLO (ART. $5^{\circ}$.) E A OUTORGA ONEROSA DO DIREITO DE CONSTRUIR (ART. $8^{\circ}$.).

Revisão da alternativa escolhida, decisão formal e divulgação: PROMOVER AUDIÊNCIAS PÚBLICAS E DEBATES COM A PARTICIPAÇÃO, DAR PUBLICIDADE AOS DOCUMENTOS E INFORMAÇÕES E GARANTIR O ACESSO A QUALQUER INTERESSADO, CONTEMPLADO NO ART. $40^{\circ}$.

Implementar e monitorar a ação estratégica:

PREVER SISTEMA DE ACOMPANHAMENTO E CONTROLE (ART. $42^{\circ}$.) E REVISÃO PERIÓDICA DA LEI (ART. 40 ${ }^{\circ}$.).
AAE

Identificar objetivos e indicadores de AAE; Incluir questões ambientais e de sustentabilidade.

Descrever a base de referência ambiental; Identificar as áreas problemas; Identificar conexões com outras ações estratégicas.

Identificar alternativas (mais) sustentáveis
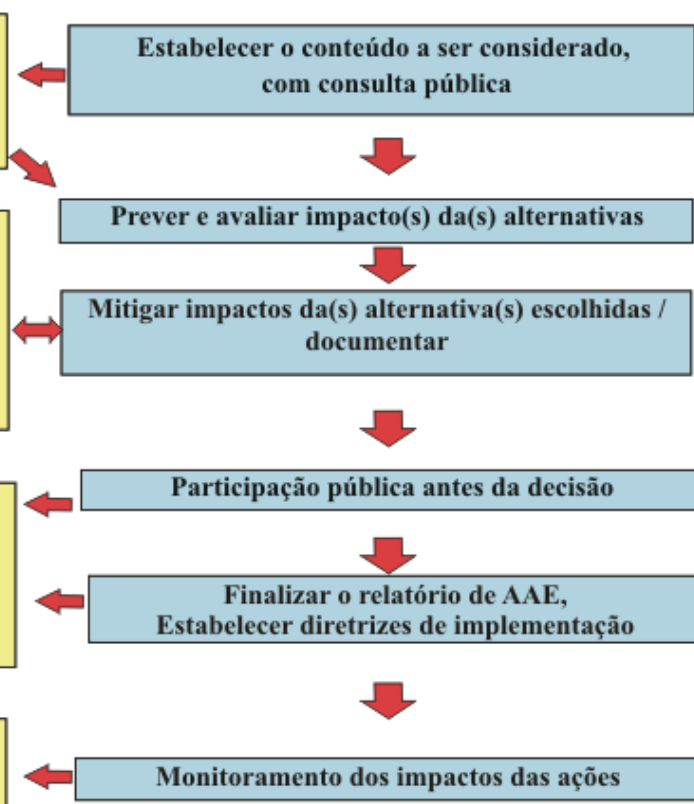

Figura 21 - Ligações entre AAE, tomada de decisão e Estatuto da Cidade (Baseado em THERIVEL, 2004 e OLIVEIRA, 2008)

A Figura 21 mostra que alguns procedimentos exigidos pelo Estatuto da Cidade coincidem com alguns dos procedimentos estipulados pela Diretiva Européia da AAE. A avaliação de planos de uso do solo, que é um requisito da Diretiva Européia de AAE, pode ajudar na preparação de políticas de planejamento que apóiem os objetivos do Estatuto da Cidade. Entre os procedimentos estão: 
1. A realização de um diagnóstico, isto é, a análise das informações da base de referência.

2. Conexões com outras ações estratégicas;

3. O desenvolvimento de procedimentos de monitoramento;

4. O desenvolvimento de consulta pública e procedimentos de participação da sociedade.

As bases de referência estão no centro da preparação dos relatórios ambientais, que é um dos produtos-chave da Diretiva Européia de AAE, a qual estipula que o relatório ambiental deve descrever as características ambientais da maneira pela qual a área será afetada pela implementação do plano, devendo também considerar os problemas ambientais existentes na área (CARTER \& HOWE, 2005).

Quanto maior o número de informações e de mais dados de bases de referência, as autoridades de planejamento estarão mais bem preparadas para direcionar os padrões de controle de uso e ocupação do solo ou estipular condições mais restritivas ao desenvolvimento, frisando-se que estes devem estar comprometidos com os objetivos de sustentabilidade estipulados pelo Estatuto da Cidade.

O direcionamento do tipo de desenvolvimento a ser adotado pelo poder público deve satisfazer a função social da propriedade, que de acordo com o art. 186 da CF (1988), o que significa atender simultaneamente, dentre outras, ao aproveitamento racional, a utilização adequada dos recursos naturais disponíveis e a preservação do meio ambiente e a observância das disposições que regulam as relações de trabalho.

As questões relacionadas com os dados de bases de referência se apresentam como uma tarefa difícil. O fragmentado regime da política ambiental, na qual diferentes organizações operam de maneira independente, não contribui para a reunião das bases de referência de forma integrada (CARTER \& HOWE, 2005).

Ao realizar conexões com outras ações estratégicas, como por exemplo, os Planos de Bacia Hidrográfica, poderiam ser incorporadas as informações, objetivos e metas disponíveis nestes planos, contribuindo para a consolidação dos dados de bases de referência, ao mesmo tempo em que estimularia a integração dos interesses das diferentes organizações que operam a política ambiental da área em questão.

A coleta de das informações que constituem a base de referência deve ser utilizada para aferir indicadores selecionados a partir dos objetivos para avaliar o desempenho da 
implementação da proposta. Uma estrutura consistente de indicadores que digam respeito ao uso e ocupação do solo pode ajudar também no desenvolvimento de procedimentos de monitoramento para auxiliar na implementação do Estatuto da Cidade, se aproximando da Diretiva Européia de AAE.

O monitoramento representa mais um dos significativos processos de ligação entre os requerimentos da Diretiva Européia da AAE e o Estatuto da Cidade. O monitoramento pode trazer numerosos benefícios, incluindo o estabelecimento da precisão da previsão de impactos realizados durante a AAE, o refinamento das técnicas de avaliação e a determinação de que as ações do PDMSC estejam sendo desempenhadas como pretendidas.

A responsabilidade pelo monitoramento pode ser compartilhada, e assim, também incorporar a participação da sociedade. O Estatuto da Cidade atribui importância à consulta pública e à participação da sociedade como um esforço para integrar as diferentes percepções ambientais nos Planos Diretores Municipais (VILLAÇA, 2005). Isso pode encorajar uma aproximação mais colaborativa e integrada para o gerenciamento do uso e ocupação do solo. O envolvimento da sociedade na coordenação e integração durante as etapas de preparação e avaliação do PDMSC deve permitir que eles expressem suas preferências e valores acerca da política de uso do solo.

Vista de forma coletiva, por uma perspectiva integrada e sinérgica, o Estatuto da Cidade e a Diretiva Européia de AAE representam uma oportunidade de garantir incrementos tangíveis no planejamento municipal de uso e ocupação do solo e, além disso, de questões ambientais mais amplas.

\subsection{CONTRIbUiÇÕES DA REALIZAÇÃO DA AAE PARA OS PLANOS MUNICIPAIS DE USO E OCUPAÇÃO DO SOLO E PARA O PLANO DIRETOR MUNICIPAL DE SÃO CARLOS}

A AAE tem aparecido como maneira de integrar AIA e planejamento participativo na promoção da sustentabilidade do uso e ocupação do solo municipal (SHEPERD \& ORTOLANO, 1996). O planejamento de uso e ocupação do solo, como é o caso do Plano Diretor Municipal de São Carlos, segue o modelo participativo. Os estudos de experiências práticas demonstraram o potencial da AAE para contribuir para o planejamento municipal de uso e ocupação do solo sustentável. Ao mesmo tempo, as práticas revelam algumas dificuldades de explorar completamente o potencial da AAE. 
A AAE e o processo de planejamento foram bem integrados em alguns dos casos estudados, exceto para Sollentuna. No caso de Hertfordshire, princípios da sustentabilidade foram guiados pela preparação da estrutura do plano desde o início (RUMBLE \& THERIVEL, apud SHEPHERD \& ORTOLANO, 1996). No caso de San Joaquin, AAE e o plano geral foram relacionados, mas o surgimento das propostas dos empreendedores, ao invés dos princípios de sustentabilidade, dirigiu o processo de planejamento (SKEWES-COX, apud SHEPHERD \& ORTOLANO, 1996). No caso de Rotterdan e Leinden, a AAE contribuiu para uma melhor hierarquização das políticas em diferentes níveis decisórios (FISCHER, 2007).

O caso de Hertfordshire, San Joaquin e Ottawa demonstram o valor da coordenação prévia (SHEPERD \& ORTOLANO, 1996). O caso sueco demonstra o valor de aprender com a experiência. Os pesquisadores suecos aprenderam no primeiro caso, em Sollentuna, como atingir a integração da $\mathrm{AAE}$ com o planejamento participativo no segundo caso, realizado em Karlskoga. O estudo sueco considerou que a AAE precisa ser integrada de maneira mais prévia e simultânea ao planejamento participativo (ASPLUND \& HILDING-RYDEVIK, apud SHEPHERD \& ORTOLANO, 1996).

A AAE possibilitou o exame prévio de impactos gerados no território municipal por políticas, planos e programas. Os impactos foram avaliados de maneira mais prévia nos casos, exceto em Sollentuna. Os casos apresentados examinaram os impactos da área de desenvolvimento (ASPLUND \& HILDING-RYDEVIK, apud SHEPHERD \& ORTOLANO, 1996). No caso da experiência de Amsterdam, a previsão de impactos possibilitou que a opção pelo crescimento tenha sido menos influenciada por considerações econômicas (FISCHER, 2007).

A análise dos impactos cumulativos não foi explicita nos casos de Sollentuna, Karlskoga e Ottawa. Sendo que, a consideração dos impactos cumulativos está relacionada com a definição do escopo de modo participativo para o planejamento de uso e ocupação do solo (SHEPERD \& ORTOLANO, 1996).

Os valores dos impactos consequentes da avaliação em cascata, assim como as análises necessárias para os projetos específicos, foram reconhecidos nos casos avaliados. Ottawa salientou o fortalecimento das ligações entre AAE e EIA, assim a AAE pôde complementar alguns requerimentos dos níveis de projeto (MCKINNON \& JOYNER, apud SHEPHERD \& ORTOLANO, 1996). No caso de Ketzin, a experiência permitiu a geração de informações para a elaboração de termos de referência de AIA (FISCHER, 2007). 
Nos casos apresentados foram incluídas medidas mitigadoras, sendo que Hertfordshire, San Joaquin e Ottawa incluíram programas de monitoramento (SHEPHERD \& ORTOLANO, 1996). No caso de Ketzin, áreas de compensação foram estipuladas caso existam impactos que não possam ser mitigados (FISCHER, 2007).

Nos casos apresentados houve o envolvimento da população nas tomadas de decisão. Os resultados dos estudos das experiências práticas mostram que a AAE pode ser um método efetivo para integrar os princípios de sustentabilidade dentro do planejamento participativo no nível municipal (SHEPHERD \& ORTOLANO, 1996). No caso de Oldham, a AAE contribuiu para a mudança dos pontos de vistas dos atores envolvidos ao propiciar o debate pela defesa dos diferentes interesses (FISCHER, 2007). Já na análise geral feita para as experiências da Alemanha, foi identificada a falta de consideração das questões levantadas nas consultas públicas (JENKS, 2005).

Alguns dos estudos mostraram as barreiras institucionais e organizacionais para AAE. Em Sollentuna, as barreiras resultaram dos consultores ligados a projetos particulares (ASPLUND \& HILDING-RYDEVIK, apud SHEPHERD \& ORTOLANO, 1996). Em San Joaquin, propostas dos empreendedores surgiram e dominaram o processo de planejamento (SKEWES-COX, apud SHEPHERD \& ORTOLANO, 1996). Na experiência de Weiz, as recomendações da AAE não forma incluídas no planejamento em função das pressões políticas e interesse dos investidores (FISCHER, 2007). Já no caso de Ottawa, houve grande suporte governamental para integrar a avaliação ambiental e as exigências do planejamento municipal (MCKINNON \& JOYNER, apud SHEPHERD \& ORTOLANO, 1996).

Nos casos de Monção e Mid Devon, apresentados nos relatórios estudados no Capítulo 4.3, os indicadores selecionados para mensurar o estado atual de uso e ocupação do solo e o desempenho das mudanças foram selecionados nas bases de referência a partir dos objetivos e metas determinados e, às vezes, foram utilizados para avaliar o desempenho de mais de tema. Cada tema, por sua vez, foi avaliado por um conjunto de indicadores (CMM, 2008 e MDDC, 2006).

Nos dois relatórios apresentados anteriormente no Capitulo 4.3 se identifica preocupações com o manejo adequado dos recursos naturais presentes nas áreas rurais, assim como um melhor aproveitamento da infraestrutura disponível em área urbana e a preocupação em recuperar o patrimônio histórico da área central dos municípios. Nestas experiências a preocupação com o turismo é utilizada para alavancar os investimentos, e conseqüentemente, conseguir a valorização da área rural, o que pode ser entendido como uma estratégia para manter a população no campo e diminuir as demandas do crescimento urbano. De uma 
maneira geral, se pode deduzir que ambas as experiências são estratégias baseadas na gestão dos recursos naturais e patrimônio construído para solucionar demandas econômicas, tirando proveito das consequências sinérgicas e cumulativas.

O uso dos indicadores e a compreensão da interação entre os diversos temas permitem que sejam identificados alguns impactos cumulativos e sinérgicos da implantação das ações estratégicas. Desta maneira, a elaboração dos cenários de uso e ocupação do solo e a respectiva alternativa selecionada poderão incorporar medidas mitigadoras aos impactos decorrentes a médio e longo prazo, e também direcionar a gestão das questões dos projetos consequentes.

No caso do planejamento municipal de uso do solo realizado em São Carlos, o processo de tomada de decisão estratégica sobre o uso e a ocupação do solo pode ser representado por meio do processo de elaboração do Plano Diretor Municipal, conforme ilustrado na Figura 22.

A Figura 22 ilustra o tratamento individualizado do tema uso e ocupação do solo, o qual não acompanha as demandas identificadas e já incorporadas pelo discurso oficial proferido na $4^{\mathrm{a}}$. Conferência da Cidade, pela interação e integração entre setores e níveis de governo. Não há indicadores e metas ambientais a considerar. Assim como os resultados identificados em outro estudo de caso realizado por Oliveira (2008), a articulação e integração entre as Políticas, os Planos e os Programas é um grande desafio da sustentabilidade na esfera municipal no Brasil. Adotar uma visão integrada e multi-direcional, associada aos outros planos e programas, pode contribuir para as decisões dos gestores municipais e também para o processo de planejamento e gestão integrada das múltiplas ações e interesses da cidade (OLIVEIRA et. al, 2009).

A caracterização de um processo decisório desvinculado da incorporação da variável ambiental realça a linearidade do processo e seu baixo potencial de integração, sejam de questões ambientais, sejam de questões setoriais ou intergovernamentais como aquelas já identificadas pela $4^{\text {a }}$. Conferência da Cidade, expressas nas discussões dos eixos temáticos $3 \mathrm{e}$ 4 descritos ao fim do Capítulo 6.3 deste trabalho. 


\section{Plano Diretor Municipal de São Carlos: (COMO FOI - SEM AAE)}

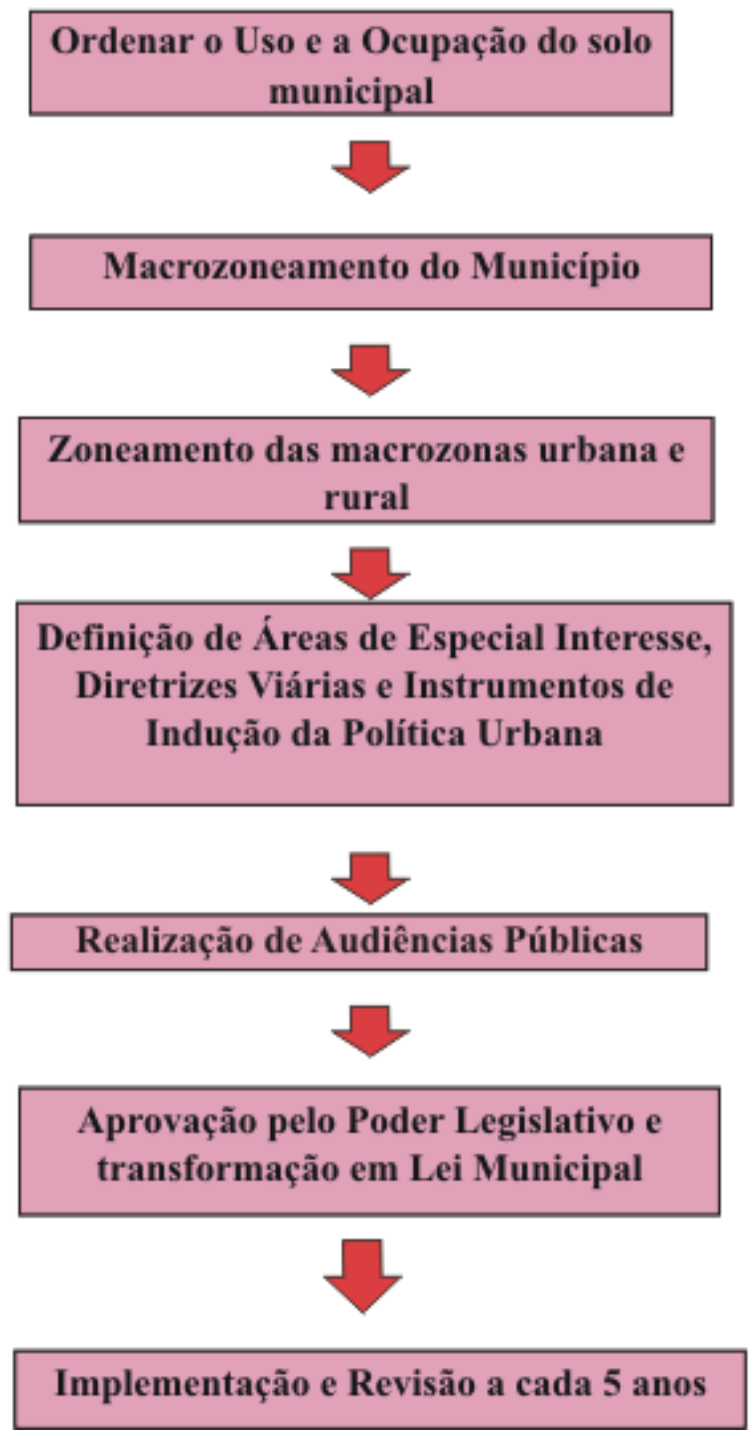

Figura 22 - Esquema das etapas do PDMSC

Caso fosse realizada uma AAE, as etapas de formulação do PDMSC seriam incrementadas com a inserção da variável ambiental em diferentes momentos, conforme ilustrado na Figura 23. As setas entre as duas colunas ilustram como se daria a integração da variável ambiental ao longo do processo de planejamento, e a possibilidade de fortalecimento mútuo entre os diferentes instrumentos apresentados. Os balões ao lado do esquema apresentado exemplificam algumas das possíveis contribuições dentre os instrumentos de planejamento existentes, assim como os incrementos sensíveis nas diferentes dimensões abordadas tanto nos impactos analisados como nos cenários de planejamento. 


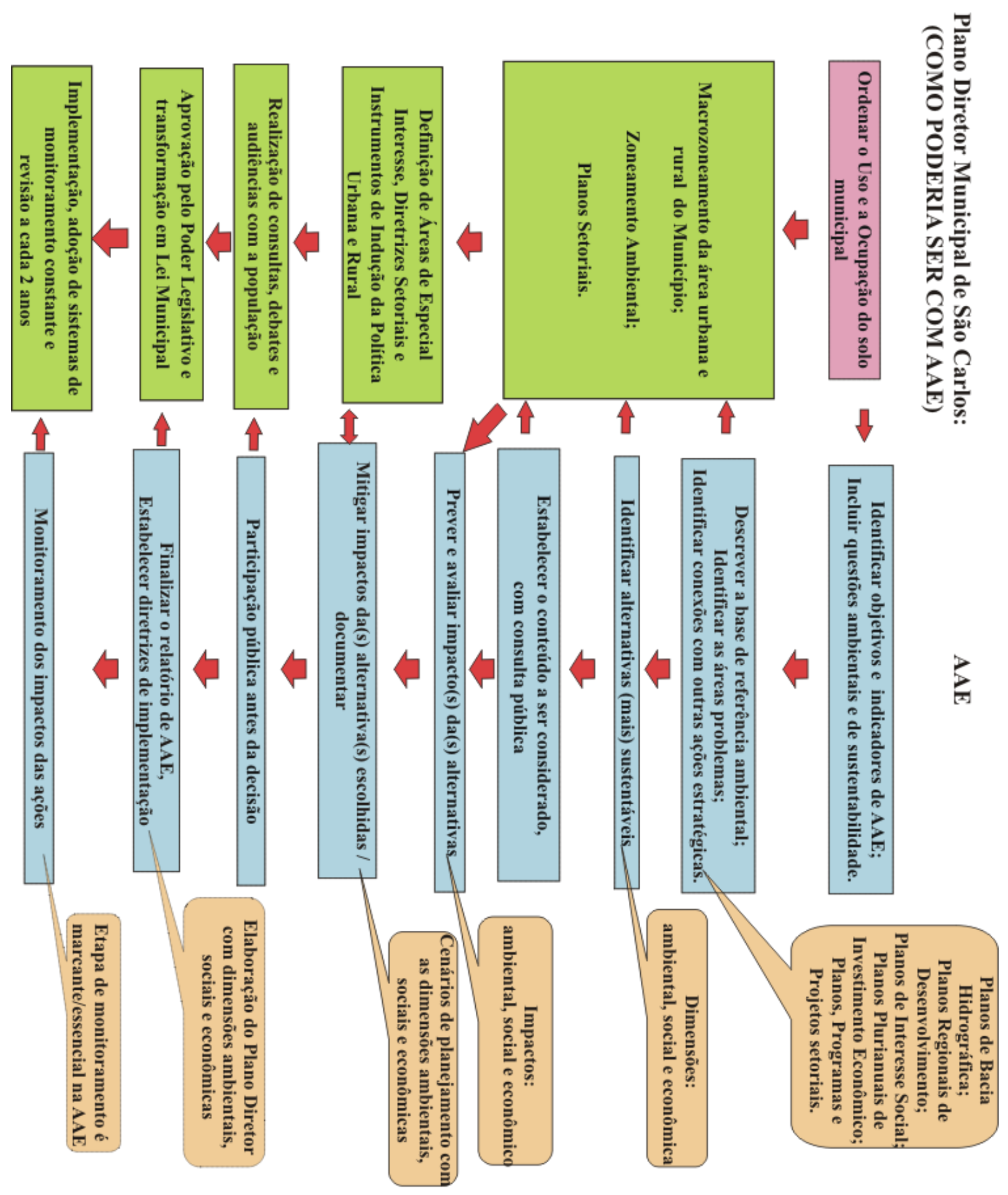

Figura 23 - Esquema das etapas do PDMSC com AAE 
De acordo com os resultados esperados e descritos pela literatura, o modelo apresentado ilustra a possibilidade de utilizar a AAE como elo de integração para subsidiar diferentes planos, contribuindo para a construção das decisões com respaldo nas informações da base de dados ambientais, permitindo o aumento do comprometimento dos gestores e planejadores em função da maior transparência e envolvimento dos atores sociais. No caso da elaboração do Plano Diretor Municipal de São Carlos, estão envolvidos diferentes órgãos setoriais da administração pública, empreendedores da iniciativa privada, representantes da sociedade civil organizada e agentes da sociedade em geral.

A realização de uma $\mathrm{AAE}$ temática de uso e ocupação do solo que contemple o PDMSC permitiria inserir a variável ambiental logo nas suas primeiras etapas de elaboração. A coleta de informações e dados para a composição das bases de referência poderia ser complementada com as informações e dados disponíveis em outros instrumentos de gestão da mesma área, mas pertencentes a outros níveis de decisão, como os Planos de Bacia Hidrográfica, os Planos Regionais de Desenvolvimento, os Planos de Interesse Social, os Planos Plurianuais de Investimento Econômico e outros planos, programas e projetos setoriais. Desta maneira, o estabelecimento dos objetivos do PDMSC poderia ser integrado aos objetivos dos diferentes planos, promovendo assim a conexão com outros instrumentos de planejamento.

Como produto desta incorporação, ao PDMSC poderia ser somado à realização do macrozoneamento de todo o território municipal, incluindo a área urbana e rural, promoveria a realização de um zoneamento ambiental e traçaria direcionamentos para a formulação e implementação dos planos setoriais, sejam eles de política urbana ou rural.

Esta integração aproximaria as alternativas possíveis de serem realizadas dos objetivos de sustentabilidade estipulados pelo Estatuto da Cidade, atribuindo considerações das dimensões ambientais, sociais e econômicas para o processo de formulação do PDMSC. O processo de consulta a sociedade seria fortalecido pela disponibilização e sistematização das informações coletadas.

Desta maneira, os diferentes setores da sociedade poderiam defender seus interesses, respaldados pelas diferentes percepções ambientais, considerando as interações dos fatores sociais e econômicos. Assim, a avaliação dos efeitos cumulativos e sinérgicos que poderiam incidir em longo e médio prazo na área seria viabilizada, e diferentes cenários de uso e ocupação do solo poderiam ser elaborados.

A partir da discussão coletiva, seria selecionada a alternativa a ser implementada, sendo que as possíveis medidas mitigadoras para os efeitos da implementação poderiam ser 
elaboradas. Caso as decisões tomadas pelo poder público não venham a acompanhar as orientações determinadas pela $\mathrm{AAE}$, os atores interessados e a comunidade estariam aptos a identificar as motivações que influenciaram as decisões tomadas, sejam elas por inclinações políticas, econômicas ou sociais. O PDMSC poderia considerar as dimensões ambientais, sociais e econômicas para a definição, por exemplo, das Áreas de Especial Interesse, das diretrizes setoriais e nas áreas onde incidirão os instrumentos de indução da política urbana e rural.

A realização de consultas, debates e audiências com a população poderiam ser realizadas não somente durante a instrumentação do plano, como ocorreu no processo de formulação do PDMSC, mas ser incorporados antes da tomada de decisão pelo poder público, como na etapa de revisão do escopo dos estudos e na definição do diagnóstico. Os estudos e relatórios ambientais realizados durante a AAE poderiam auxiliar no entendimento do conteúdo dos planos municipais de uso e ocupação do solo, oferecendo indicadores que sejam capazes de mensurar a evolução das ações implantadas, do desempenho das características ambientais do meio e das possibilidades de intervenção para o redirecionamento, caso seja identificado tendências não desejadas durante a implementação do Plano.

A posterior aprovação do conteúdo e direcionamentos do PDMSC pelo Poder Legislativo e a transformação do Plano em Lei Municipal iria estar mais próxima da realidade local, atribuindo maior credibilidade e aceitação das decisões tomadas pelo poder público municipal.

A implementação do PDMSC seria acompanhada de um sistema de monitoramento, que sendo constantemente realizado, iria atualizar as informações dos dados das bases de referência, otimizando o processo de revisão periódica do PDMSC. As ações de monitoramento, estabelecidos pela análise e acompanhamento dos indicadores selecionados a partir dos objetivos propostos, poderiam ser compartilhadas junto a outros setores da sociedade, promovendo um acompanhamento da gestão pública e aumentando a legitimidade das decisões tomadas por um processo democrático de discussão e distribuição das responsabilidades, o que consolidaria o processo de descentralização da administração pública.

Deste modo o PDMSC estaria mais apto para regular os direcionamentos do uso e ocupação do solo municipal visando os interesses da coletividade na busca por um equilíbrio ambiental, efetivando desse modo a função social da propriedade urbana e rural, conforme indicado na Constituição Federal do Brasil. 


\section{CONCLUSÕES}

A pesquisa indica que a AAE pode ajudar a atingir os objetivos de sustentabilidade pela avaliação do PDMSC com integração de outros planos relevantes como os Planos de Bacia Hidrográfica, Planos de Desenvolvimento Econômico e Social e outros planos, programas e projetos setoriais. A integração de outros PPPs segue o escopo da Diretiva Européia de AAE, a qual pode realizar uma significativa contribuição para a realização dos objetivos do Estatuto da Cidade.

AAE representa uma oportunidade para enfatizar os pontos fortes e fracos de planos e programas específicos do PDMSC e para o fortalecimento do conteúdo de outros PPPs, nos termos de sua aproximação com a gestão da política municipal. Ao invés de exigir modificações dos procedimentos, AAE tem o potencial significativo de contribuir para criação das alternativas dos planos de uso e ocupação do solo e suas políticas para fortalecer as decisões a serem tomadas pelo poder público, de modo que permita às práticas de planejamento a contemplar a função social da propriedade.

A integração dos procedimentos participativos pode ajudar a romper as tradicionais barreiras entre disciplinas e grupos de interesses, particularmente durante o processo de geração de soluções para os problemas do uso e ocupação do solo. A consulta integrada à sociedade e os procedimentos de participação devem ser conduzidos de modo a direcionar as questões sociais, econômicas e ambientais de maneira que sirvam de base para os procedimentos para a gestão da sustentabilidade no uso e ocupação do solo municipal.

Assim como exigido pela Diretiva Européia de AAE, a avaliação de impactos do PDMSC pode envolver questões diversas como saúde humana, fatores climáticos e biodiversidade, fortalecendo uma perspectiva mais holística da gestão do uso e ocupação do solo.

Não só do ponto de vista do conteúdo temático, a AAE pode estimular o desenvolvimento da integração dos atores envolvidos nos procedimentos e monitoramento para encorajar o gerenciamento da sustentabilidade do uso e ocupação do solo. Os procedimentos de monitoramento também permitem que autoridades competentes determinem quando a implementação do Plano está ao encontro aos objetivos do Estatuto da Cidade, fortalecendo as ações de remediação a serem tomadas quando necessárias.

Enfim, os instrumentos irão somar a força de trabalho para as autoridades competentes responsáveis pela implementação das ações de planejamento. Ao explorar as possibilidades para a integração em consonância com a Diretiva Européia da AAE, se pode explorar 
sinergias com a contribuição para a redução do impacto da implementação da legislação, melhorando o planejamento municipal ao encontro da gestão democrática da cidade. 


\section{BIBLIOGRAFIA}

ALSHUWAIKHAT, H. M. - Strategic Environmental Assessment can help solve environmental impact assessment failures in developing countries Environmental Impact Assessment Review - v.25, n.4, p.307-317 - Amsterdan, 2004;

BRAGA, R. - Estatuto da Cidade - in: BRAGA, R. \& CARVALHO, P. F. (orgs.) Estatuto da Cidade: política urbana e cidadania - LPM-IGCE-UNESP - Rio Claro, 2000

BRAND, P. \& THOMAS, M. J. - Urban Environmentalism. Global change and the mediation of local conflict - Routledge - London, 2005;

BRASIL - Resolução CONAMA 01 de 1986 - Elaboração de Estudos de Impacto Ambiental;

BRASIL, Constituição Federal de 1988;

BRASIL, Lei Federal 10257 de 2001 - Estatuto da Cidade;

BRASIL, Lei Federal 6938 de 1981 - Política Nacional do Meio Ambiente;

BURGESS, R. - The Compact City Debate: A Global Perspective - in: JENKS, M. \& BURGESS, R. (editors) - Compact cities. Sustainable Urban Forms for Developing countries - Spon Press - London, 2000;

BURGESS, R.; CARMONA, M.; \& KOLSTEE, T. - The challenge of Sustainable cities. Neoliberalism and urban strategies in developing countries - ZED BOOKS London, 1997;

CAHN, M. A. - Environmental Deceptions - the tension between Liberalism and Environmental Policymaking in the United States - State University of New York Press. Albany, 1995;

CÂMARA MUNICIPAL DE MONÇÃO - Avaliação Ambiental Estratégica. Relatório Ambiental. Plano Director Municipal Monção - CMM, 2008. On-line http://www.lugardoplano.pt

CARMONA, M. - The Regional Dimension of the Compact City Debate: Latin America - in: JENKS, M. \& BURGESS, R. (editors) - Compact cities. Sustainable Urban Forms for Developing countries - Spon Press - London, 2000;

CARTER, J. \& HOWE, J. - The water framework directive and the Strategic Environmental Assessment Directive: exploring the linkages - Environmental Impact Assessment Review - v.5, n.1, p.1-14 - Amsterdan, 2005; 
COELHO, M. C. N. - Impactos Ambientais em áreas urbanas - teorias, conceitos e métodos de pesquisa - in: GUERRA, A. J. T. \& CUNHA, S. B. (org.) - Impactos ambientais urbanos no Brasil - $2^{\mathrm{a}}$. Ed - Bertrand Brasil - Rio de Janeiro - 2004;

CUllingworth, B. \& NADIN, V. - Town and Country Planning in the UK - $13^{\mathrm{a}}$. Ed, Routledge - London \& NY, 2002;

DALAL-CLAYTON, B. \& BASS, S. - Sustainable Development Strategies. A Resource Book - Earthscan, Lodon - 2002;

DALAL-CLAYTON, B. \& SADLER, B. - Strategic Environmental Assessment. A Sourcebook and Reference Guide to International Experience - EarthScan, London; 2005

DEPARTAMENTO DE ÁGUAS E ENERGIA ELÉTRICA - Plano Estadual de Recursos Hídricos: primeiro plano do Estado de São Paulo - São Paulo, 1990;

DEPARTAMENTO DE ÁGUAS E ENERGIA ELÉTRICA - Plano Estadual de Recursos Hídricos 2004-07 - São Paulo, 2007;

DEVESCOVI, R. C. B. - Urbanização e acumulação: um estudo sobre a cidade de São Carlos - Ed. Ufscar - São Carlos, 1987;

EUROPEAN UNION. The European Parlaiment - Directive 2001/42/EC of the European Parliament and of the Council on the assessment of the effects of certain plans and programmes on the environment. Disponível em http://www.environ.ie/en/publications/environment/miscellaneous/filedownload,180 5,en.pdf, Acesso em 26 de maço 2009;

FABBRO NETO, F. - Performances ao Centro - Trabalho de Graduação - EESC:USP, 2004;

FABBRO NETO, F. \& SOUZA, M. P. - Avaliação Ambiental Estratégica e Desenvolvimento Urbano: Contribuições para o Plano Diretor Municipal Revista Minerva Pesquisa e Tecnologia, v.1, n.6, p.85-90 - Editora Fipai - São Carlos, 2009

FISCHER, T. B. - Theory \& Pratctice of SEA. Towards a more systematic approach. Earthscan - Londres, 2007;

GENElETTI, D.; BAGLI, S.; NAPOLITANO, P. \& PISTOCCHI, A. - Spatial decision support for strategic environmental assessment of land use plans. A case study in southern Italy - in: Environmental Impact Assessment Review - v.27, n.1, p.408423 - Amsterdan, 2007; 
GLASSON, J., THERIVEL, R. e CHADWICK, A. - Introduction to environmental impact assessment - Spon Press, 2005;

JACOBI, P. - A percepção dos problemas ambientais urbanos em São Paulo - in: FERREIRA, L. C. \& VIOLA, E. (org.) - Incertezas de sustentabilidade na globalização - Ed. Unicamp - Campinas, 1996;

JENKS, M. - Conclusion: The appropriateness of compact city concepts to developing countries - in: JENKS, M. \& BURGESS, R. (editors) - Compact cities. Sustainable Urban Forms for Developing countries - Spon Press - London - 2000

JOÃO, E. - The importance of data and scale issues for Strategic Environmental Assessment - Environmental Impact Assessment Review, v.27, n.1, p.361-364 Amsterdan, 2007;

KARSTENS, S.; BOTS, P.; SLINGER, J. - Spatial boundary choice and the views of different actors - in: Environmental Impact Assessment Review, v.27, n.1, p.386407 - Amsterdan, 2007;

MARICATO, E. - Brasil, Cidades. Alternativas para a crise urbana. - Editora Vozes Petrópolis, 2001

MARICATO, E. - Meio Ambiente e Reforma Urbana - disponível em: http://www.fag.edu.br/professores/deniseschuler/1\%BA\%20SEM\%202008/PUR\%20 II/Trabalho\%202\%BA\%20bimestre/Textos\%20de\%20apoio/meio.amb_ref.urb.pdf 1994;

MID DEVON DISTRICT COUNCIL - Sustainability Appraisal/Strategic Environmental Assessment - MDDC, 2006;

MINISTÉRIO PÚBLICO FEDERAL - $4^{\mathrm{a}}$. Câmara de Coordenação e Revisão Deficiências em estudos de impacto ambiental: síntese de uma experiência Escola Superior do Ministério Público da União - Brasília, 2004;

MOL, A. P. J. - Ecological modernization: industrial trasnformations and environmental reform. In: REDCLIFT, M. (editor). The international Handbook of Environmental Sociology. Cheltenham, UK. Northampton, MA, USA. 1997;

MONTEIRO, C. A. F. - Teoria e clima urbano - FFLCH:USP - São Paulo, 1975

MUKAI, T. - Direito Urbano-Ambiental Brasileiro - Ed. Dialética - São Paulo, 2002;

OLIVEIRA, I. S. D. - A contribuição do zoneamento ecológico econômico na avaliação de impacto ambiental: bases e propostas conceituais - Dissertação (mestrado) EESC:USP - São Carlos, 2004; 
OLIVEIRA, I. S. D. - Alternativas para a implementação da Avaliação Ambiental Estratégica no Brasil - Tese (doutorado) EESC:USP - São Carlos, 2008;

OLIVEIRA, I. S. D., MONTAÑO, M., SOUZA, M. P. - Avaliação Ambiental Estratégica - Suprema Gráfica e Editora - São Carlos, 2009;

PAOLI, M. C. - A era da indeterminação - Relatório parcial do subprojeto 8 da pesquisa Cidadania e Democracia: O pensamento nas rupturas da política. - Fapesp - São Paulo, 2002;

PARTIDÁRIO, M. R. - Avaliação Ambiental Estratégica - Brasília - MMA, 2002;

PIRES, L. R. G. M. - Função Social da propriedade urbana e o plano diretor - Editora Fórum - Belo Horizonte, 2007;

PREFEITURA MUNICIPAL DE SÃO CARLOS - Conferência Municipal da Cidade PMSC, 2003 - CD-ROOM;

PREFEITURA MUNICIPAL DE SÃO CARLOS - Lei Municipal 13.691 de 2005 - Plano Diretor do Município;

PREFEITURA MUNICIPAL DE SÃO CARLOS - Regimento da 4a . Conferência Municipal da Cidade - PMSC, 2009;

REINKE, M. - Urban Planning and Strategic Environmental Assessment - in: SCHMIDT , M., JOÃO, E. \& ALBRECHT, E. - Implementing Strategic Environmental Assessment - Springler-Verlag, Berlim - 2005;

ROO, G. \& MILLER, D (editors) - Compact cities and sustainable urban development: A critical assessment of policies and plans from an international perspective (Urban Planning and Environment) - Ashgate Publishing Limited - Reino Unido, 2000;

SADLER, B. \& VERHEEM, R. - Environmental Assessment of Policies: Briefing papers on experience in selected countries - VROM - Holanda, 1996;

SÁNCHEZ, L. E. - Avaliação de Impacto Ambiental: conceitos e métodos - Oficina de Textos - São Paulo, 2006;

SÁNCHEZ, L. E. \& SILVA-SÁNCHEZ, S. S. - Tiering strategic environmental assesssment and projetc environmental impact assessment in highway planning in São Paulo, Brazil - Environmental Impact Assessment Review, v.28, n.1, p.515522 - New York, 2008;

SÉGUIN, E. - Estatuto da Cidade - Editora Forense, Rio de Janeiro - 2002; 
SHEPHERD, A. \& ORTOLANO, L. - Strategic Environmental Assessment for Sustainable Urban Development - Environmental Impact Assessment Review, v.6, n.1, p.321-335 - Amsterdan, 1996;

SILVA, A. N. R., RAIA JR, A. A., FERRAZ, A. C. P. - Minimizing the Negative Effects of Urban Sprawl: Towards a Strategy for Brazil - in: JENKS, Mike \& BURGESS, Rod (editors) - Compact cities. Sustainable Urban Forms for Developing countries - Spon Press - London, 2000;

SILVA, J. A. - Direito Urbanístico Brasileiro - Malheiros Editores - 4ª Ed. - São Paulo, 2006 ;

SILVA, S. R. M. \& TEIXEIRA, B. A. N. - O Estatuto da Cidade: a abordagem ambiental em Lei Federal de orientação básica aos Planos Diretores Municipais - in: Anais do VI Congresso de Meio Ambiente da Associação de Universidades do Grupo de Montevidéu - São Carlos - UFSCar 2009;

SOUZA, M. P. - Instrumentos de Gestão Ambiental: fundamentos e prática - Ed.Riani Costa - São Carlos, 2000;

STEPHAN, I. I. C. - Planos Diretores e Leis do Uso do Solo: Sua aplicação em cidades de médio porte. - Anais XII ENANPUR - Belém, 2007;

THERIVEL, R \& ROSS, B. - Cumulative effects assessment: Does scale matter? Environmental Impact Assessment Review - v.27, n. 1, p.365-385 - Amsterdan, 2007 ;

THERIVEL, R. - Strategic Environmental Assessment: in action - Earthscan, 2004;

TRUZZI, O. M. S. - Café e indústria: São Carlos 1859-1950 - São Carlos - Edufscar, 2000 .

VILLAÇA, F. - As ilusões do plano diretor - São Paulo, Ed. do autor, 2005. On-line http://www.flaviovillaca.arq.br/pdf/ilusao_pd.pdf - Maio, 2009 downloaded. 